\title{
Review of the Species of New World Erythroneurini \\ (Hemiptera: Cicadellidae: Typhlocybinae) \\ II. Genus Zyginama
}

Christopher H. Dietrich and Dmitry A. Dmitriev 
Illinois Natural History Survey, David L. Thomas, Chief

A Division of the Illinois Department of Natural Resources

\author{
Illinois Natural History Survey \\ Distribution Office \\ I-Building \\ 1816 South Oak Street \\ Champaign, IL 61820
}

Citation:

Dietrich, C.H., and D.A. Dmitriev. 2008. Review of the New World Erythroneurini (Hemiptera:

Cicadellidae: Typhlocybinae). II. Genus Zyginama. Illinois Natural History Survey Bulletin

38(3):129-176.

\title{
Editor: Charles Warwick
}

US ISSN 0073-4918

\section{US ISBN 1-882932-16-1}

Printed by authority of the State of Illinois

(C) 2008

P0172233-.75M-04-08

Printed with soy ink on recycled and recyclable paper.

Equal opportunity to participate in programs of the Illinois Department of Natural Resources (IDNR) and those funded by the U.S. Fish and Wildlife Service and other agencies is available to all individuals regardless of race, sex, national origin, disability, age, religion, or other non-merit factors. If you believe you have been discriminated against, contact the funding source's civil rights office and/or the Equal Employment Opportunity Officer, IDNR, One Natural Resources Way, Springfield, IL 62702-1271; 217/785-0067; TTY 217/782-9175. 


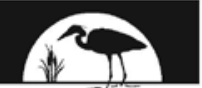

ILLINOIS

NATURAL

HIS TORY

S URVEY

\section{Review of the Species of New World Erythroneurini}

\section{(Hemiptera: Cicadellidae: Typhlocybinae) \\ II. Genus Zyginama}

Christopher H. Dietrich and Dmitry A. Dmitriev

Illinois Natural History Survey Bulletin

Volume 38, Article 3

April 2008

Illinois Natural History Survey,

1816 S. Oak St.,

Champaign, IL 61820, USA,

dietrich@inhs.uiuc.edu 


\section{Contents}

Acknowledgements......................... iv

Abstract. . . . . . . . . . . . . . . . . . . . . . . . . . . . . . 129

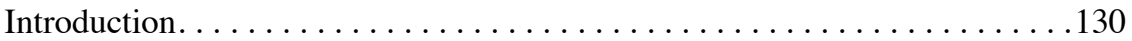

Methods. . . . . . . . . . . . . . . . . . . . . . . . . . . . . . . . . . . . 130

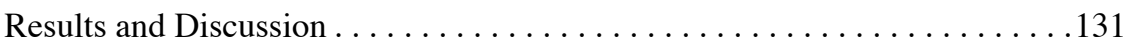

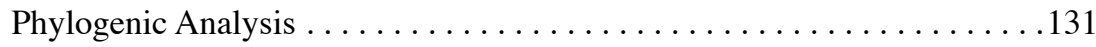

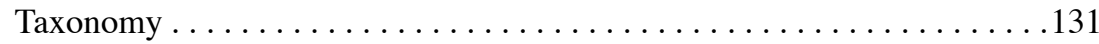

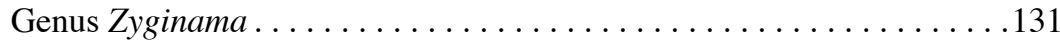

Key to Males of North American Species of Zyginama . . . . . . . . . . . 132

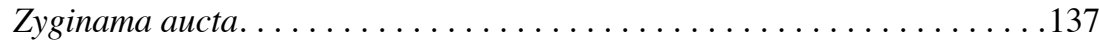

Zyginama merita...............................137

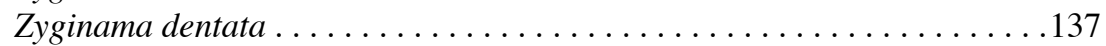

Zyginama grandis................................ 137

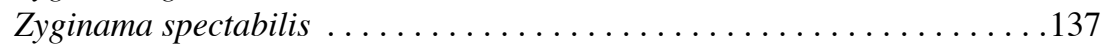

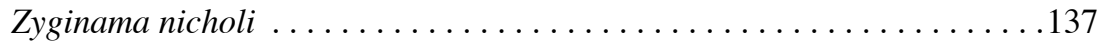

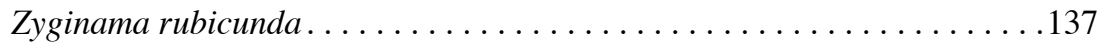

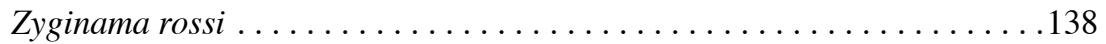

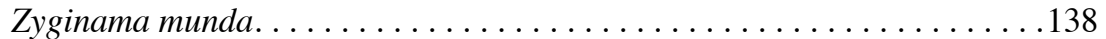

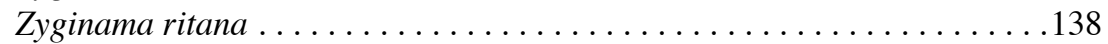

Zyginama maculipennis .............................139

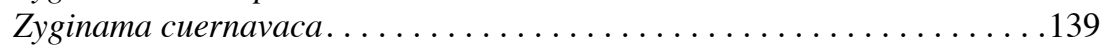

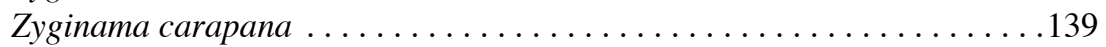

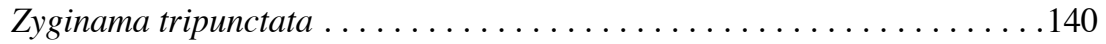

Zyginama coahuilensis . . . . . . . . . . . . . . . . . . . . . . . . .140

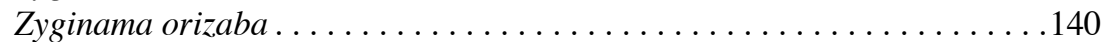

Zyginama rodmani .................................141

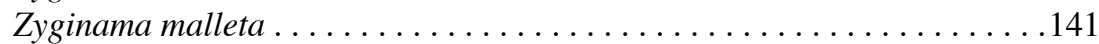

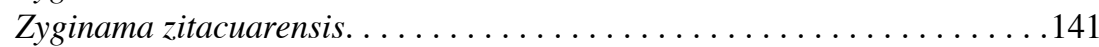

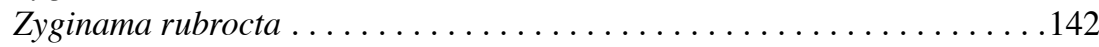

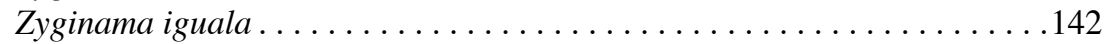

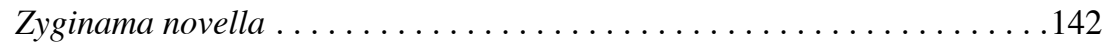

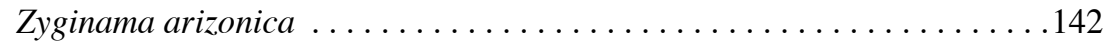

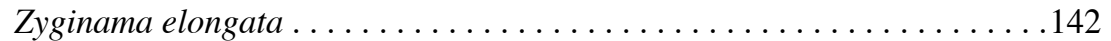

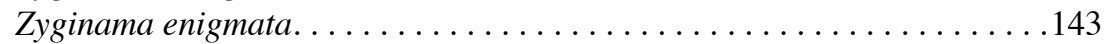

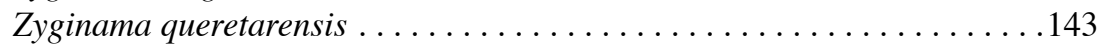

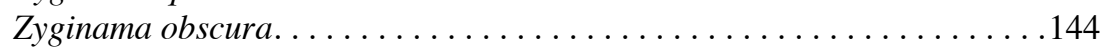

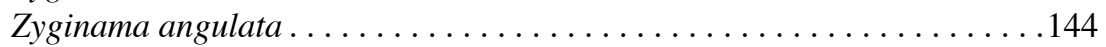

Zyginama durangensis . . . . . . . . . . . . . . . . . . . . . . . . . . . . .

Zyginama unicolor . . . . . . . . . . . . . . . . . . . . . . . . . . . . 144

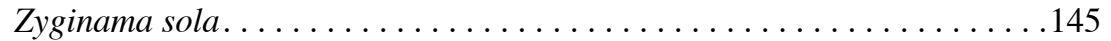

Zyginama cornigera ............................. 145

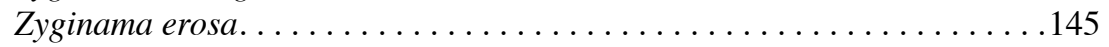

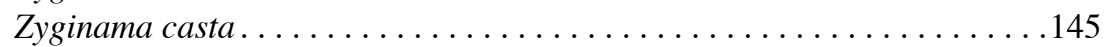

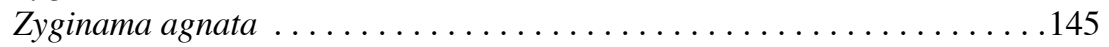

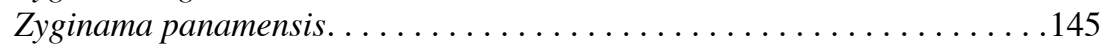

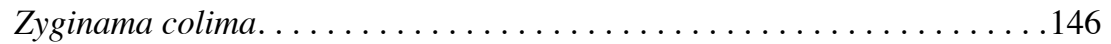

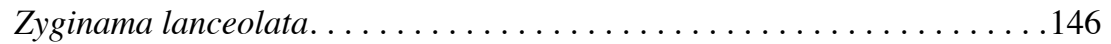

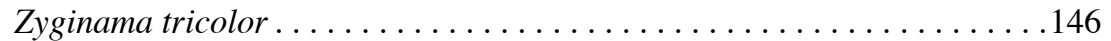

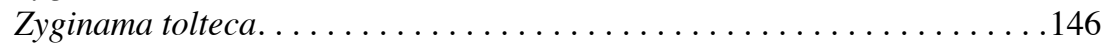




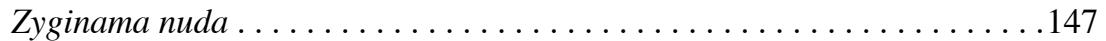

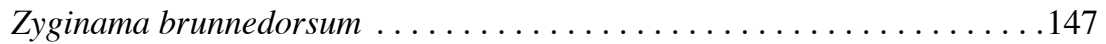

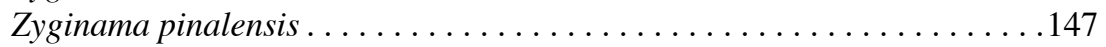

Zyginama triceroprocta . ..................................

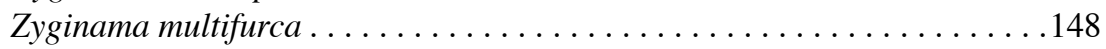

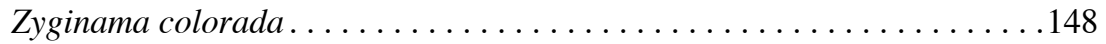

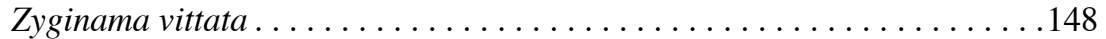

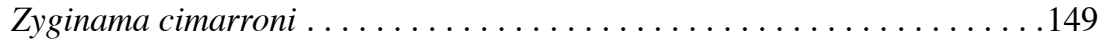

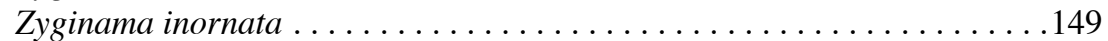

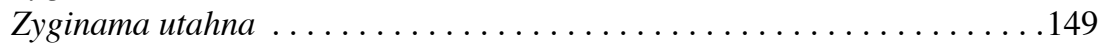

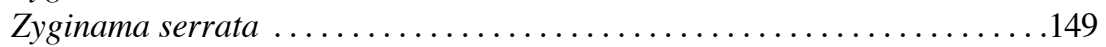

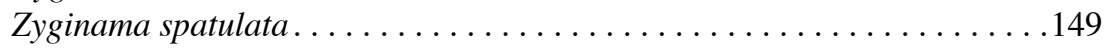

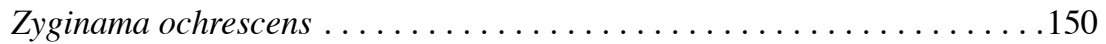

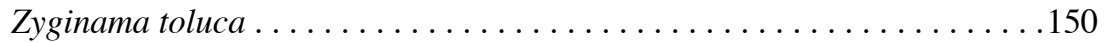

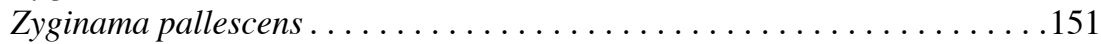

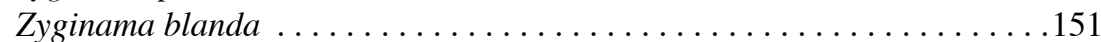

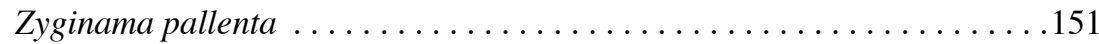

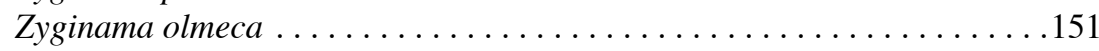

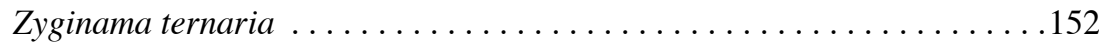

Key to South American Species Provisionally Placed in Zyginama. . . . . . 153

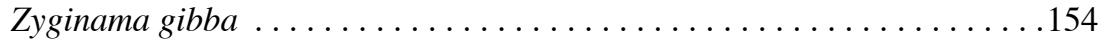

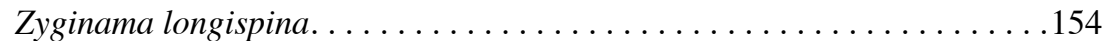

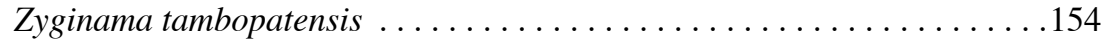

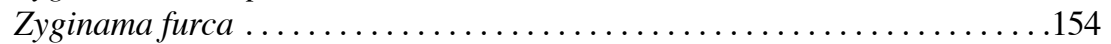

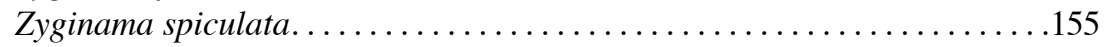

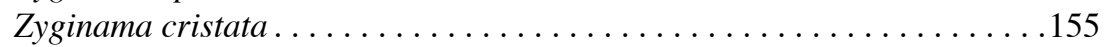

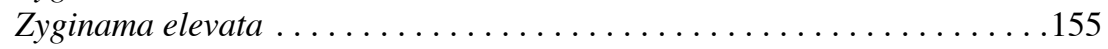

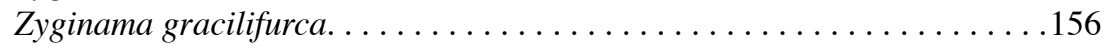

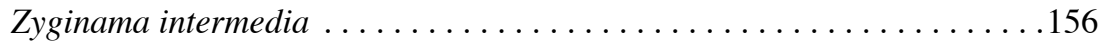

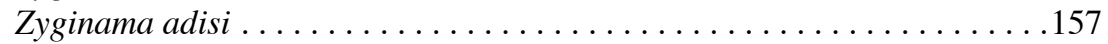

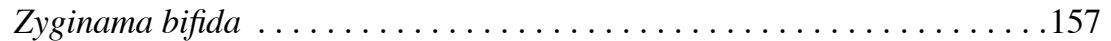

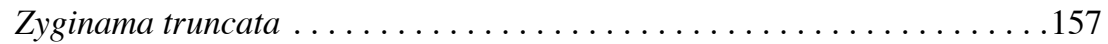

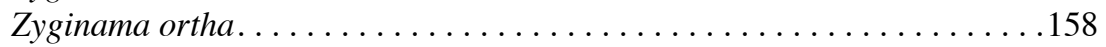

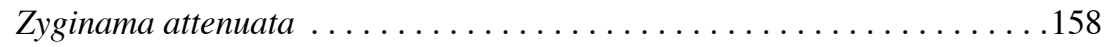

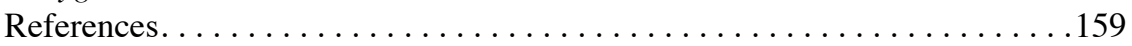

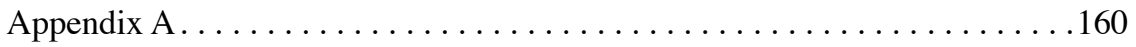

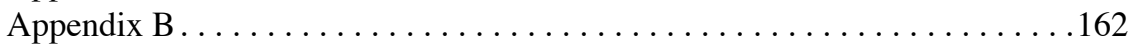

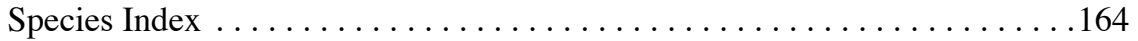

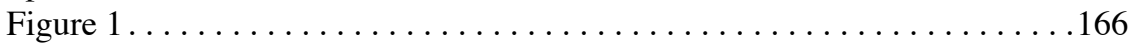

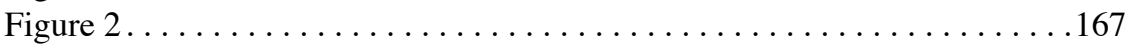

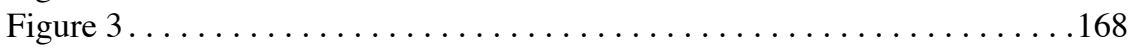

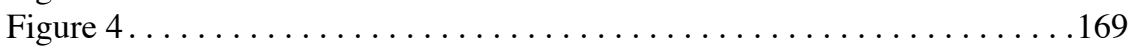

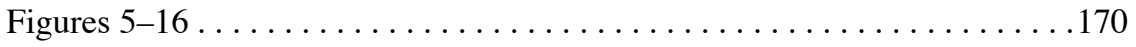

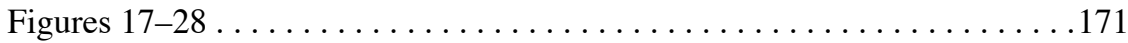

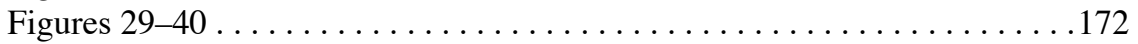

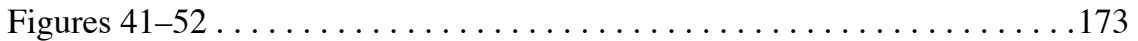

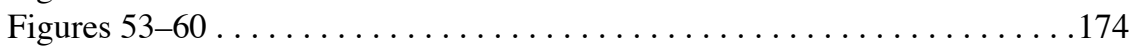

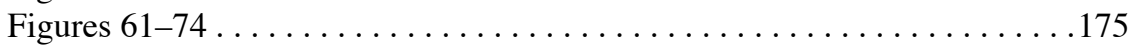




\section{Acknowledegments}

For lending specimens, we are grateful to K.G.A. Hamilton (CNC), C. Freeman (OSU), Z. Falin (KU), E. Riley (TAMU), and S. McKamey (USNM). We also thank G. Moya-Raygoza, H. Brailovsky, and R. Mariño for facilitating field work in Mexico, and T. Erwin and W. Steiner for access to the Smithsonian Amazonian canopy fogging samples. The manuscript was substantially improved based on the comments of two anonymous referees on an earlier version. This work was funded in part by NSF grants DEB-0315373 and DEB-0529679. 


\title{
Review of the Species of New World Erythroneurini \\ (Hemiptera: Cicadellidae: Typhlocybinae)
}

II. Genus Zyginama

\begin{abstract}
The 35 previously described species (including 4 junior synonyms) of the New World erythroneurine leafhopper genus Zyginama are reviewed and descriptions are provided for 43 new species, 2 from U.S.A., 26 from Mexico, 1 from Panama, and 14 from the Amazon region of South America. The following new synonyms are recognized: Z. aucta (McAtee) equals Erythroneura bilocularis Van Duzee, syn. n., and E. inclita Beamer, syn. n.; Z. nicholi (Beamer) equals E. canyonensis Beamer, syn. n., and E. ales Beamer, syn. n. Separate keys are provided for identification of males from North and South America, all known species are illustrated, and data on their distributions are summarized. Phylogenetic analysis of 40 morphological characters of the 71 species for which males are known yielded a reasonably well resolved estimate of relationships among the included species, but branch support was low overall.
\end{abstract}

Key words: Auchenorrhyncha, distribution, Homoptera, identification, morphology, phylogeny, taxonomy. 


\section{Introduction}

The genus Zyginama was recently established (Dietrich and Dmitriev 2006) to receive most species of the "Zygina ritana species group" recognized by Young (1952). Species in this genus differ from other New World Erythroneurini in having the male pygofer with both dorsal and ventral appendages and a group of enlarged setae ventrolaterally near the base, the anal tube (abdominal segment X) lacking distinct spines, and the aedeagus without a large, unpaired dorsal subbasal process. Species of the genus are very poorly known. Most are recorded from a single locality and host-plant records are lacking for all but a few species. This first attempt to review the genus based on the sparse material available in collections accentuates the need for further collecting and phylogenetic study of the group. The 35 previously recognized species of Zyginama are recorded primarily from the southwestern U.S.A. Forty-three additional species, described below, extend the known range of the genus south through Mexico and Central America to Ecuador, Peru, and Brazil. Further collecting in the Neotropical region will undoubtedly lead to the discovery of many additional species of Zyginama. The morphology-based phylogenetic analysis of Dietrich and Dmitriev (2006) recovered the included representatives of $Z y$ ginama as a monophyletic group within a larger clade comprising the mostly North American genera Aztegina, Mexigina, Hepzygina, and Neozygina, but that analysis included only three species of Zyginama.

Available host records for species recorded from the southwestern U.S.A. indicate that North American species of Zyginama occur on trees and shrubs, particularly Quercus spp., but no ecological data are available for the majority of species.

This paper synthesizes available morphological, distributional, and host plant data for the known species of Zyginama; and provides an estimate of phylogenetic relationships among species, an illustrated key for species identification, and descriptions of new species.

\section{Methods}

Morphological terminology follows Dietrich and Dmitriev (2006). Specimens examined, including primary types of all previously described species, are housed in the following collections: California Academy of Sciences, San Francisco (CAS); Canadian National Collection, Ottawa (CNC); Illinois Natural History Survey, Champaign (INHS); U.S. National Museum of Natural History, Washington (USNM); Ohio State University, Columbus (OSU); University of Kansas, Lawrence (KU); Texas A\&M University, College Station (TAMU). Verbal species descriptions are provided only for new species; morphological data for previously described species are summarized in a data matrix (Appendix B). In the "Notes" section for previously described species, the average length of males and females examined is given because many original descriptions did not include measurements. Because most species are known only from the type locality, and only a handful of species are recorded from more than three locations, distribution maps are not provided.

Habitus photographs were taken using a Microptics digital micrography system. For each species the best available specimen was photographed. Unfortunately, for many species only the holotype was available and several of these type specimens were in poor condition. To prepare drawings of genitalia, dissected structures were first immersed in glycerine in a well slide and photographed using a Q-Imaging Micropublisher digital camera attached to an Olympus SZX-12 dissecting microscope; the photographs were then enlarged and traced to produce line drawings. For several species, the only available male specimens had the genitalia permanently mounted on slides (Beamer and Knull collections in KU and OSU, respectively). Because pressure from the cover slip tends to distort the structures to various degrees, in the illustrations of these species, the pygofer appendages are extended away from the pygofer margins to a greater degree than they would appear in unmounted specimens. Also, for these species (noted below), it was not possible to illustrate the aedeagus in posterior view.

Many species of New World Erythroneurini are known to exhibit considerable color polymorphism (Dietrich and Dmitriev 2007, Dmitrev and Dietrich 2007). Unfortunately, the degree of intraspecific color polymorphism was impossible to assess for most Zyginama species given the paucity of available specimens. Thus, our delimitation of species was based on features of the male genitalia, which we 
consider to be more reliable than color pattern. Some taxa previously distinguished based on coloration but lacking distinct differences in the male genitalia (e.g., Z. nicholi Beamer and its junior synonyms) are here treated as synonyms. Besides coloration, characters were not found for distinguishing species based on females. Thus, at present, females of many species may only be identified through their association with males.

To assess phylogenetic relationships among species of Zyginama, a data matrix comprising coded states for 40 morphological characters (Appendices A and B) was compiled and analyzed under the maximum parsimony criterion using PAUP* 4.0 (Swofford 1998) on a Powermac G5 computer. All characters received equal weight in the analysis, but states of some multistate characters were arranged in hypothetical transformation series and treated as ordered (= additive; see Appendix A). Tree searches were conducted using the heuristic search option with TBR branch swapping of 1000 random taxon addition sequence replicates and a maximum of 500 trees retained in each replicate. Trees were rooted to the outgroup taxon Mexigina oculata (McAtee). To measure relative branch support, the Bremer decay index was calculated using the method described by Dietrich and Dmitriev (2006).

\section{Results and Discussion}

\section{Phylogenetic Analysis}

The analysis of morphological data yielded 1270 equally parsimonious trees of length $=$ 400 , consistency index $=0.185$, and retention index $=0.528$. The Adams consensus of these trees (Fig. 1) was almost completely resolved, but branch support was low, with nearly all consistently resolved branches receiving Bremer support of 1 and no branch receiving support $>3$. Several clades comprise easily recognizable groups based on features of the male genitalia or color pattern, and recognition of new genera for some of these may eventually be warranted.

Most South American species grouped toward the base of the tree as a paraphyletic grade giving rise to the main North American lineage. Only two species recorded from North America (Z. ochrescens, n. sp., and Z. serrata, n. sp.) were consistently recovered as sister groups to species endemic to South America. Other clades comprising both North and South American species were not recovered in all most parsimonious trees.

\section{Taxonomy}

Typhlocybinae Kirschbaum Erythroneurini Young

Zyginama Dietrich \& Dmitriev Zyginama Dietrich \& Dmitriev, 2006:149 (type species Erythroneura ritana Beamer).

Description. Crown moderately to strongly produced medially, with or without pair of indistinct red or brown preapical spots; overall coloration usually pale yellow, variously marked with red or brown, or without distinct markings. Forewing lacking distinct brown or black spots in apical cells; inner apical cell with base oblique. Male pygofer with dorsal appendage well developed, immovably fused to pygofer margin; without macrosetae basad of dorsal appendage (except $Z$. intermedia, n. sp.); ventral appendage present (except $Z$. cornigera (Beamer)), usually elongate; basolateral setal group usually conspicuous, with one or more enlarged setae (reduced or absent in some species). Style apex truncate, footlike, with only two points, preapical lobe well developed. Connective U-shaped, without median anterior lobe, arms short. Aedeagus with dorsal apodeme usually well developed, T-shaped in posterior view, without sclerotized connection to dorsal pygofer appendage or anal tube; shaft usually with paired processes basally, distally, or both; unpaired processes, when present basally, not strongly separated from shaft.

Distribution. Southern USA, south to Brazil and Peru.

Notes. The genus as currently defined is somewhat heterogeneous and recognition of additional genus-group taxa within this assemblage will probably become warranted once the fauna is better known. In particular, several new species from the Amazonian region of Peru and Brazil, although sharing key features with North American Zyginama, are similar to various endemic South American erythroneurine genera in coloration and the shape of the head, and, therefore, are only tentatively included in Zyginama (see discussion below).

Because there is no apparent overlap in the species composition of North and South America, separate keys are provided for males from these two continents. 


\section{Key to Males of North American Species of Zyginama}

(excluding Z. dentata (Gillette) [Fig. 2C] and Z. ternaria (Van Duzee) [Fig. 3EE], known only from females)

1 Aedeagus with one or more long spinelike processes arising near base of shaft (Figs. 5b, 7b) rarely arising at or slightly beyond midlength, Fig. 34c), extended distad; distal processes may also be present

1'Aedeagus without long spinelike processes, or if such processes present, arising distinctly distad of shaft midlength and extended laterad or basad (Figs. 44c, 48c)

2(1) Aedeagus without paired distal processes (angulate flanges or small teeth may be present) (Figs. 5c, 17c)

2' Aedeagus with one or more pairs of conspicuous distal processes (Figs. 9b, 10b)

3(2) Aedeagus with unpaired basal process closely appressed to shaft, shaft slender, tapered in lateral view, with posterior surface troughlike (Figs. 5b, c) ...

3' Aedeagus with basal processes paired, shaft broad or, if slender, not troughlike posteriorly

(Figs. 7b, c)

4(3) Length of male $<2.7 \mathrm{~mm}$, dorsum with conspicuous red markings (Fig. 2A); apex of aedeagus in posterior view distinctly emarginate (Fig. 5c)... 1. Z. aucta (McAtee) 4' Length of male $>2.7 \mathrm{~mm}$, dorsum red markings inconspicuous or absent (Fig. 2B); apex of aedeagus in posterior view rounded with weak medial notch (Fig. 6c).

5(3) Aedeagal shaft in lateral view with apex tapered or parallel-sided (Fig. 7b)

5' Aedeagal shaft in lateral view with apex distinctly expanded (Fig. 19b).....

6(5) Aedeagal shaft in posterior view parallel-sided or evenly tapered towards apex, without lateral teeth or flanges (Fig. 7b) ................................................................................................... 6 ' Aedeagal shaft in posterior view with angulate lateral tooth or flange preapically (Fig. 17c) ... 14

7(6) Pygofer lobe with dorsal margin concave preapically, apex not including ventral appendage

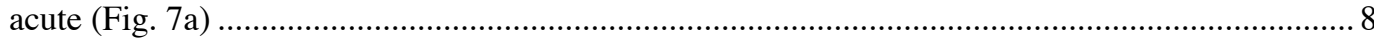

7' Pygofer lobe with dorsal margin convex preapically, apex not including ventral appendage broadly rounded

8(7) Body length $>3 \mathrm{~mm}$; aedeagus with dorsal apodeme in lateral view slender, parallel-sided; basal processes extended nearly to apex of shaft (Fig. 7b)... 4. Z. grandis (Beamer) 8 ' Body length $<3 \mathrm{~mm}$; aedeagus with dorsal apodeme in lateral view strongly broadened dorsally; basal processes not extended beyond midlength of shaft (Fig. 8b)

9(7) Aedeagus with shaft in lateral view broadest near midlength, crescent-shaped

9' Aedeagus with shaft in lateral view parallel-sided or tapered toward apex (Fig. 14b)

10(9) Forewing without red markings (Fig. 2K); pygofer with dorsal appendage extended to apex of lobe (Fig. 11a); aedeagus in posterior view with shaft apex acuminate (Fig. 11c) .

10 ' Forewing clavus with conspicuous red transcommisural maculae (Fig. 2L); pygofer with dorsal appendage not extended to apex of lobe (Fig. 12a); aedeagus in posterior view with shaft apex broadly rounded 
11(9) Forewing with conspicuous red markings (Fig. 2M)

12(11) Aedeagal shaft in lateral view nearly straight, subequal in length to preatrium; basal processes extended nearly to shaft apex (Fig. 13b); pygofer dorsal appendage tapered, without preapical spine (Fig. 13a). 11. Z. maculipennis, n. sp. 12' Aedeagal shaft recurved apically, longer than preatrium; basal processes less than half length of shaft (Fig. 14b); pygofer dorsal appendage acuminate, with slender preapical spine (Fig. 14a) ...

12. Z. cuernavaca, n. sp.

13(11) Crown without paired spots (Fig. 2O); aedeagal shaft in lateral view with apex evenly rounded, without posterior preapical heel (15b) . 13. Z. carapana, n. sp. 13' Crown with pair of brown preapical spots (Fig. 2P); aedeagal shaft in lateral view footlike, with distinct posterior preapical heel (Fig. 16b) 14. Z. tripunctata (Beamer)

14(6) Aedeagal shaft in posterior view with pair of small toothlike projections near apex (Fig. 17c), in lateral view with apex slightly curved and blunt (Fig. 17b)

15. Z. coahuilensis, $\mathrm{n}$. sp. 14' Aedeagal shaft in posterior view with pair of angulate lateral flanges (Fig. 18b), in lateral view with attenuate apical extension bent at nearly right angle to remainder of shaft (Fig. 18c)

16. Z. orizaba, n. sp.

15(5) Aedeagal shaft in posterior view with pair of angulate lateral flanges (Fig. 19c), in lateral view without angulate projection on dorsal margin (Fig. 19b) 17. Z. rodmani, n. sp. 15' Aedeagal shaft in posterior view without pair of angulate lateral flanges (Fig. 20b), in lateral view with angulate projection on dorsal margin at or basad of midlength (Fig. 20c).....

16(15) Aedeagal shaft in lateral view with falcate posteroapical projection, dorsal angulate projection near base (Fig. 20b) 18. Z. malleta, n. sp. 16' Aedeagal shaft in lateral view without falcate posteroapical projection, dorsal angulate projection near midlength (Fig. 21b) 19. Z. zitacuarensis, n. sp.

17(2) Aedeagal shaft with single spinelike basal process posteriorly (22b, c) 18 17' Aedeagal shaft with pair of spinelike basal processes (Fig. 25b, c) 20

18(17) Aedeagus with posterior preapical projection (Fig. 23b); pygofer with dorsal appendage not bent abruptly ventrad in distal half (Fig. 23a) ....

18' Aedeagus without posterior preapical projection; pygofer with dorsal appendage bent abruptly ventrad in distal half (Fig. 22a). 20. Z. rubrocta, n. sp.

19(18) Aedeagus with posterior preapical projection falcate, shaft with auriculate basolateral lobes (Fig. 23b) 21. Z. iguala (Ross) 19' Aedeagus with posterior preapical projection blunt, shaft without auriculate basolateral lobes (Fig. 24b). 22. Z. novella (Knull \& Auten)

20(17) Aedeagus in lateral view attenuate apically (Fig. 9b); pygofer with dorsal margin concave preapically, apex (not including ventral appendage) acute (Fig. 9a)

20' Aedeagus in lateral view with apex truncate or bluntly rounded (Fig. 25b); pygofer with dorsal margin convex preapically, apex (not including ventral appendage) rounded (Fig. 25a).

21(20) Dorsal color pattern consisting of bold transverse reddish bands, crown pale without distinct markings (Fig. 2F) ..6. Z. nicholi (Beamer) 21 ' Dorsal color pattern consisting of large symmetrically arranged reddish spots, crown with paired red or brown spots (Fig. 2J) 
22 Aedeagus with basal processes straight; paired distal processes broad, rounded (Fig. 9b) ....... 7. Z. rubicunda (Beamer) 22' Aedeagus with basal processes abruptly bent anterad preapically; paired distal processes slender, acuminate (Fig. 10b)..... 8. Z. rossi, n. sp.

23(20) Aedeagus in lateral view with unpaired acute compressed projection just posteroventrad of gonopore (Fig. 25b) 24 23 ' Aedeagus in lateral view with area just posteroventrad of gonopore flat or rounded (Fig. 28b)..

24(23) Aedeagus with gonopore in lateral view entire, shaft with pair of angulate subbasal projections on dorsal margin (Fig. 25b). 23. Z. arizonica (Knull \& Auten) 24' Aedeagus with gonopore in lateral view emarginate, shaft without angulate subbasal projections on dorsal margin (Fig. 26b). 24. Z. elongata, n. sp.

25(23) Aedeagus with apex in lateral view bent dorsad at $90^{\circ}$ angle to remainder of shaft (Fig. 27b)

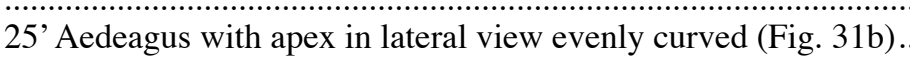

26(23) Aedeagal shaft in lateral view with dorsal and ventral margins strongly arcuate, basal processes strongly divergent from shaft (Fig. 27b)..... 25. Z. enigmata, n. sp. 26' Aedeagal shaft in lateral view with dorsal and ventral margins nearly straight (Fig. 28b) ...... 27

27(26) Aedeagal shaft in lateral view broad basally, abruptly narrowed near midlength, distal processes flattened and angulate subbasally (Fig. 28b) 26. Z. queretarensis, n. sp. 27 ' Aedeagal shaft in lateral view slender throughout length, distal processes slender (Fig. 29b) .... 27. Z. obscura (Beamer)

28(25) Aedeagus with paired distal processes lamelliform (Fig. 30c).

29(28) Distal processes of aedeagus each with three angulate projections (Fig. 30c)

29' Distal processes of aedeagus with a single projection (Fig. 31b). 29. Z. durangensis, n. sp.

30(28) Pygofer dorsal appendage with preapical spine (Fig. 32a)

30' Pygofer dorsal appendage without preapical spine (Fig. 34a)...

31(30) Preapical spine of pygofer dorsal appendage strongly divergent (Fig. 32a) ....

31' Preapical spine of pygofer dorsal appendage not divergent (Fig. 33a)

30. Z. unicolor (Beamer)

31. Z. sola (Knull \& Auten)

32(30) Aedeagus with distal processes unbranched, subbasal processes arising near base of shaft

(Fig. 36b, c).

32' Aedeagus with distal processes branched or, if unbranched, with subbasal processes arising near midlength of shaft (Fig. 34b, c).....

33(32) Aedeagus with subbasal processes arising near midlength of shaft (Fig. 34b); pygofer without ventral appendage (Fig. 34a) 32. Z. cornigera (Beamer) 33' Aedeagus with subbasal processes arising near base (Fig. 35b); pygofer with ventral appendage well developed (Fig. 35a) ..... 
34(32) Aedeagus in posterior view with distal processes extended ventrolaterad (Fig. 36c) 34. Z. casta (Beamer)

34' Aedeagus in posterior view with distal processes extended dorsolaterad (Fig. 37c). 35. Z. agnata (Knull \& Auten)

35(1) Aedeagus without paired distal processes (Figs. 38b, 39b).

35' Aedeagus with paired processes arising at or beyond midlength of shaft (Fig. 44b)

36(35) Aedeagal shaft with angulate subbasal dorsal projection (Fig. 39b)....

37(36) Aedeagus with unpaired asymmetrical process posteroventrad of gonopore (Figs. 38b, c) ... 36. Z. panamensis, n. sp.

37' Aedeagus without unpaired process posteroventrad of gonopore 38

38(37) Aedeagal shaft in lateral view with apex bluntly rounded (Fig. 39b); pygofer dorsal appendage branched (Fig. 39a). 37. Z. colima, n. sp.

38' Aedeagal shaft with apex lanceolate (Fig. 40b); pygofer dorsal appendage unbranched (Fig. 40a).... 38. Z. lanceolata, n. sp.

39(37) Aedeagal shaft in lateral view S-shaped, apex terminating in median posteroventrally directed spine (Fig. 41b) 39. Z. tricolor (Beamer) 39' Aedeagal shaft in lateral view recurved, apex without median spine

40(39) Aedeagus with gonopore arising near apex of shaft (Fig. 42b); pygofer dorsal appendage straight, strongly divergent from lobe (Fig. 42a) 40. Z. tolteca, n. sp. 40' Aedeagus with gonopore arising near base of shaft (Fig. 43b); pygofer dorsal appendage sinuate, weakly divergent from lobe (Fig. 43a). 41. Z. nuda (Knull \& Auten)

41(35) Aedeagal shaft with more than one pair of lateral projections distad of midlength (Fig. 45b, c).

41'Aedeagal shaft with one pair of branched or unbranched lateral projections distad of midlength

42(41) Aedeagus in lateral view with shaft distinctly arcuate, with dorsoapical projection forming ca. $90^{\circ}$ angle with remainder of shaft (Fig. 45b).

42' Aedeagus in lateral view with shaft straight or recurved, dorsoapical projection if present not forming $90^{\circ}$ angle with remainder of shaft (Fig. 46b)

43(42) Aedeagus in lateral view with unpaired distal process strongly recurved, lateral processes much longer than maximum width of shaft in posterior view (Fig 44b) ...... Z. brunnedorsum, n. sp. 43' Aedeagus in lateral view with unpaired distal process straight, lateral processes little if any longer than maximum width of shaft in posterior view (Fig. 45b).... 43. Z. pinalensis(Beamer)

44(42) Aedeagus without preatrium; shaft with pair of distally branched preapical projections (Fig. 46b).....

44' Aedeagus with preatrium well developed, more than half length of shaft; shaft without branched preapical projections (Fig. 48b)

45(44) Pygofer with dorsal appendage slender, acuminate (Fig. 46a).

45' Pygofer with dorsal appendage broad, apex bifid (Fig. 47a). 
46(44) Aedeagus with ventrally directed spine ventrad of gonopore (Fig. 48b)

46' Aedeagus without ventrally directed spine ventrad of gonopore

46. Z. colorada, n. sp.

47(46) Aedeagus in lateral view abruptly bent dorsad at $90^{\circ}$ angle near gonopore; paired preapical processes bifid (Fig. 49b).....

47. Z. vittata, n. sp.

47' Aedeagus in lateral view not abruptly bent, acuminate distally, with pair of slender processes

dorsad of gonopore and shorter pair of triangular projections ventrad of gonopore (Fig. 50b)

48. Z. cimmaroni (Beamer)

48(41) Pygofer dorsal appendage with angulate preapical projection (Fig. 51a)

48' Pygofer dorsal appendage acuminate or blunt, without preapical projection (Figs. 53a, 55a)......

49(48) Aedeagal shaft in lateral view broad, arcuate, apex with dorsal and ventral spines

(Fig. 51b)....

49. Z. inornata (Beamer)

49' Aedeagal shaft in lateral view slender, nearly straight; apex attenuate, without spines

(Fig. 52b)....

50. Z. utahna (Beamer)

50(48) Pygofer dorsal appendage blunt apically (Fig. 53a).......................................................51

50' Pygofer dorsal appendage acute apically (Fig. 56a).....

51(50) Pygofer dorsal appendage serrate apically (Fig. 53a); aedeagal shaft in lateral view less than twice as long as its maximum width (Fig. 53b).... 51. Z. serrata, n. sp. 51' Pygofer dorsal appendage not serrate apically; aedeagal shaft in lateral view more than twice as long as its maximum width.

52(51) Aedeagus with apex broadly angulate apically, paired processes shorter than shaft width

(Fig. 54b).

52. Z. spatulata, n. sp.

52 ' Aedeagus with apex bluntly rounded apically, paired processes longer than shaft width

(Fig. 55b).

53. Z. ochrescens, n. sp.

53(50) Aedeagus in posterior view with apex bi- or trifurcate (Figs. 56c, 57c), shaft in lateral view with dorsal margin convex (Figs. 56b) .

53' Aedeagus in posterior view with apex acuminate or rounded (Figs. 58c, 60c), shaft in lateral view concave dorsally (Figs. 58b)

54(53) Aedeagus in lateral view with processes curved anterodorsad (Fig. 56b)

54' Aedeagus in lateral view with processes extended anterovenrad (Fig. 57b)

54. Z. toluca, n. sp.

55. Z. pallescens, n. sp.

55(53) Aedeagus in posterior view with apex rounded, distal processes bifid (Fig. 58c)

56. Z. blanda (Knull \& Auten)

55' Aedeagus in posterior view with apex acuminate, distal processes acuminate (Fig. 60c).........56

56(55) Aedeagus with processes short, triangular (Fig. 59b); pygofer dorsal appendage straight (Fig. 59a).... 57. Z. pallenta (Beamer)

56 'Aedeagus with processes elongate, slender (Fig. 60b); pygofer dorsal appendage falcate

(Fig. 60a).

58. Z. olmeca, n. sp. 
1. Zyginama aucta (McAtee) (Figs. 2A, 5) Erythroneura obliqua var. aucta McAtee, 1920a:279

Erythroneura dentata bilocularis Van Duzee, 1924a: 233, new synonym

Erythroneura aucta, Beamer, 1932i:123 Erythroneura inclita Beamer, 1934a:44, new synonym

Zygina aucta, Young, 1952:75

Zyginama aucta, Dietrich \& Dmitriev, 2006:149

Type locality: San Diego Co., California [CAS].

Distribution: USA: California.

Notes: Length of male $2.8 \mathrm{~mm}$, female $3.0 \mathrm{~mm}$. Study of the holotypes of E. dentata bilocularis Van Duzee (San Diego Co., California [CAS]) and E. inclita Beamer (San Jacinto Mts., California) indicates that both are synonyms of $Z$. aucta (McAtee). McAtee's holotype is a female, but the coloration of this species is distinctive and, thus, the interpretation of Z. aucta embodied in Beamer's male "allotype" (KU) appears to be correct. Beamer (1932i) recorded Quercus douglasi as the host plant of this species.

2. Zyginama merita (Beamer) (Figs. 2B, 6) Erythroneura merita Beamer, 1932i:127 Zygina merita, Young, 1952:76

Zyginama merita, Dietrich \& Dmitriev, 2006:150

Type locality: San Jacinto Mts., California [KU].

Distribution: USA: California.

Notes: Length of male $3.5 \mathrm{~mm}$, female $3.7 \mathrm{~mm}$. Beamer (1932i) recorded this species from "live oak".

\section{Zyginama dentata (Gillette) (Fig. 2C)}

Typhlocyba dentata Gillette, 1898a:765

Erythroneura dentata, Kirkaldy, 1907d:69

Zygina dentata, Young, 1952:75

Zyginama dentata, Dietrich \& Dmitriev, 2006:149

Type locality: Folsom, California [USNM].

Distribution: USA: California.

Notes: Length of female $3.7 \mathrm{~mm}$, male unknown. To help fix the identity of the species, one of two female syntypes from Gillette's collection in the USNM (type no. 3453) is here designated lectotype. No male specimens of this species are known. This species is very similar to Z. aucta in coloration and in the shape of the seventh abdominal sternite of the female, but differs in being considerably larger.

4. Zyginama grandis (Beamer) (Figs. 2D, 7) Erythroneura grandis Beamer, 1929b: 127

Zygina grandis, Young, 1952:76

Zyginama grandis, Dietrich \& Dmitriev, 2006:150

Type locality: Oak Creek Canyon, Arizona [KU].

Distribution: USA: Arizona.

Notes: Length of male $3.5 \mathrm{~mm}$, female, $3.7 \mathrm{~mm}$.

5. Zyginama spectabilis (Knull \& Auten) (Figs. 2E, 8)

Erythroneura spectabilis Knull \& Auten 1938a:533

Zygina spectabilis, Young, 1952:76

Zyginama spectabilis, Dietrich \& Dmitriev, 2006:150

Type locality: Huachuca Mts., Arizona [OSU].

Distribution: USA: Arizona.

Notes: Length of male $3.0 \mathrm{~mm}$, female $3.1 \mathrm{~mm}$.

6. Zyginama nicholi (Beamer) (Figs. 2F-H, 9) Erythroneura nicholi Beamer, 1927a:30

Erythroneura canyonensis Beamer, 1929b:120, new synonym

Erythroneura ales Beamer, 1932i:124, new synonym

Zygina nicholi, Young, 1952:76

Zyginama nicholi, Dietrich \& Dmitriev, 2006:150

Type locality: Santa Rita Mts., Arizona (elev. 4,500 ft.) [KU].

Distribution: USA: Arizona, Utah.

Notes: Length of male $2.7 \mathrm{~mm}$, female 3.0 $\mathrm{mm}$. The taxa here treated as junior synonyms appear to represent color forms of a single species. Comparison of the male genitalia of the holotypes of E. canyonensis and E. ales to those of $E$. nicholi revealed only slight differences in the length of the basal aedeagal processes. These vary among individuals having the same coloration.

7. Zyginama rubicunda (Beamer) (Fig. 2I) Erythroneura rubicunda Beamer, 1929b: 126 Zygina rubicunda, Young, 1952:76 Zyginama rubicunda, Dietrich \& Dmit riev, 2006:150 
Type locality: Pinal Co., Arizona [KU]. Distribution: USA: Arizona.

Notes: Length of male $2.8 \mathrm{~mm}$, female 3.0 mm. Beamer's holotype of E. rubicunda [KU] is a female. Male specimens from the Huachuca Mts., Arizona [OSU] and identified as "Erythroneura rubicunda" by Knull closely resemble the female holotype in size and color pattern, and the male pygofer and genitalia are nearly identical to those of Z. nicholi (Fig. 9). Nevertheless, $Z$. rubicunda is retained as a valid species based on its distinctive coloration, which more closely resembles that of $Z$. grandis and Z. rossi, n. sp.

\section{Zyginama rossi, n. sp. (Figs. 2J, 10)}

Description. Length of male 3.1-3.3, female 3.2-3.3. Ground color pale yellow, heavily marked with reddish orange. Face mostly reddish brown with two pairs of symmetrical pale spots dorsally; crown-face transition pale yellow; crown pale yellow with pair of faint brown spots preapically near midline and pair of small orange maculae more laterad. Pronotum mostly reddish orange; midline, posterior margin, and five anterior spots pale. Mesonotum orange except pale midline; scutellum orange except pale anterolateral corners. Forewing clavus with orange maculae at base, near midlength, and at apex; corium with costal area orange basally and distad of brochosome field; orange maculae also present near midlength and apex of brachial cell and along vein $\mathrm{M}$ near midlength; apex infuscated. Venter of thorax and abdomen dark reddish brown. Head narrower than pronotum; crown in dorsal view slightly longer medially than next to eye, anterior margin forming $90^{\circ}$ angle. Head (Fig. 2J) subequal to pronotum in width; crown in dorsal view distinctly longer medially than next to eye, anterior margin forming $90^{\circ}$ angle. Male pygofer (Fig. 10a) with dorsal appendage arising near base, not elevated above margin of lobe, acuminate, slightly decurved, extended to midlength of lobe; ventral appendage arising preapically, short, curved dorsad; lobe between appendages acute, concave dorsally; ventrolateral setal group with $\sim 9$ enlarged setae. Aedeagus (Figs. $10 \mathrm{~b}, \mathrm{c})$ without preatrium; dorsal apodeme in lateral view slightly broadened dorsally; shaft in lateral view moderately broad, nearly straight, terminating in anterodorsally directed acuminate spine; with preapical pair of slender lateral processes extended ventrad; paired sub- basal processes arising posteriorly near base, closely paralleling shaft to near gonopore, with apices abruptly bent anterad; gonopore preapical on posterior surface.

Material examined. Holotype male, USA: Illinois, W. Karnak, 24 September 1952 (Ross and Evers, on Quercus lyrata); 1 female paratype, same data; 3 male and 1 female paratypes, USA: Illinois, Grantsburg, 28 August 1952 (Rich. and Stannard, on Quercus lyrata); 1 female paratype, same data except 23 September 1953 (Ross and Evers, on Quercus palustris) [INHS]; 1 male paratype, USA: Mississippi, Fulton, 15 June 1935 (D.W. Grimes) [OSU]. Notes. This species closely resembles $Z$. rubicunda (cf. Fig. 2I), but differs in having a pair of brown spots on the crown, the distal processes of the aedeagus slender and the basal processes long and abruptly bent preapically. The species is named in memory of the late Prof. H.H. Ross, collector of the holotype and a pioneer in the study of New World Erythroneurini. It is one of only two species of Zyginama recorded from east of the Mississippi River (the other being Z. tripunctata) and the only one known from the midwestern U.S.A.

9. Zyginama munda (Knull \& Auten) (Figs. 2K, 11)

Erythroneura munda Knull \& Auten 1938a:534

Erythroneura modula Knull \& Auten 1938a:535

Zygina munda, Young, 1952:76

Zyginama munda, Dietrich \& Dmitriev, 2006:150

Type locality: Chiricahua Mts., Arizona [OSU].

Distribution: USA: Arizona.

Notes: Length of male $3.0 \mathrm{~mm}$, female $3.3 \mathrm{~mm}$.

10. Zyginama ritana (Beamer) (Figs. 2L, 12) Erythroneura ritana Beamer, 1934c:286

Zygina ritana, Young, 1952:76 Zyginama ritana, Dietrich \& Dmitriev, 2006: 150

Type locality: Santa Rita Mts., Arizona [KU].

Distribution: USA: Arizona.

Notes: Length of male $3.0 \mathrm{~mm}$, female 3.2 $\mathrm{mm}$. Beamer (1934c) recorded this species from "blue oak." The illustration of the aedeagus of this species provided by Dietrich and Dmitriev (2006) omitted the paired basolateral processes of the aedeagus. 


\section{Zyginama maculipennis, n. sp. (Figs. 2M,} 13)

Description. Length of male $3.5 \mathrm{~mm}$. Ground color dull yellow; pronotum orange posteromesad; mesonotum and scutellum orange-brown; forewing with four red maculae, two on clavus and two more distad along vein $\mathrm{Cu}$. Head (Fig. $2 \mathrm{M})$ narrower than pronotum, crown in dorsal view with median length distinctly greater than length next to eye, anterior margin forming $90^{\circ}$ angle. Male pygofer (Fig. 13a) with dorsal appendage arising near midlength, not elevated above margin of lobe, short, strongly tapered, curved mesad, not extended to apex of lobe; ventral appendage arising near apex, long, curved dorsomesad; lobe between appendages rounded; ventrolateral setal group absent. Aedeagus (Figs. 13b, c) with preatrium as long as shaft; dorsal apodeme in lateral view broadly rounded; shaft in lateral view short, slender, nearly straight; paired subbasal appendages not divergent from shaft in lateral view, evenly divergent in posterior view; apex beyond gonopore compressed and attenuate; gonopore preapical on posterior surface.

Material examined. Holotype male, MEXICO, Michoacan, Carapan, $\mathrm{km}$ 432, 2 October 1941 (DeLong, Good, Caldwell, Plummer) [INHS].

Notes. This species resembles $Z$. colima in coloration but differs in having the pygofer dorsal appendage short and relatively broad, the ventrolateral setal group lacking; and the aedeagus with the preatrium elongate, the shaft very short and slender, and the basal paired processes well developed. The species name, an adjective meaning "spot wing," refers to the spotted forewings.

12. Zyginama cuernavaca, n. sp. (Figs. 2N, 14) Description. Length of male 4.0-4.2 mm, female $4.2 \mathrm{~mm}$. Ground color pale yellow; face mostly brown; crown with small dark brown spot apically; pronotum with pair of small sublateral brown spots and pair of large orange submedial triangles, posterior margin white; mesonotal triangles orange; scutellum apex black; forewing base orange, clavus with orange medial blotch, brachial cell with two orange blotches, vein $\mathrm{M}$ bordered with orange near midlength; mesosternum and abdomen except genital plates mostly dark brown. Head (Fig. 2M) narrower than pronotum; crown in dorsal view distinctly longer medially than next to eye, anterior margin forming $90^{\circ}$ angle. Male pygofer (Fig. 14a) with dorsal appendage arising near midlength, slender, straight, not elevated above pygofer margin, bifurcate distad of midlength with branches closely appressed to each other, extended slightly beyond apex of lobe; ventral appendage arising near apex, long, extended dorsomesad; lobe between appendages rounded; ventrolateral setal group with $\sim 6$ enlarged setae. Aedeagus (Figs. 14b, c) with preatrium short; in lateral view with dorsal apodeme broadened dorsad; shaft slender, irregularly recurved, tapered distally, with pair of short subbasal processes not extended beyond shaft midlength, divergent in posterior view; distal processes absent; apex in posterior view acuminate; gonopore preapical on posterior margin.

Material examined. Holotype male, MEXICO, km 66 Mexico-Cuernavaca Rd., 17 August 1936 (Ball and Stone); 3 male and 2 female paratypes, same data [OSU].

Notes. This species closely resembles $Z$. tripunctata in coloration but differs in having the dorsal pygofer appendage more elongate and divided distally into two parallel spines. The species name, an adjective, refers to the type locality.

13. Zyginama carapana, n. sp. (Figs. 2O, 15) Description. Length of male $3.3 \mathrm{~mm}$. Pale yellow overall, unmarked except black scutellum apex and fuscous maculae at base and apex of forewing costal plaque. Head (Fig. 2O) narrower than pronotum; crown in dorsal view slightly longer medially than next to eye, anterior margin forming $90^{\circ}$ angle. Male pygofer (Fig. 15a) with dorsal appendage arising near midlength, not elevated above margin of lobe, acute, bent posteroventrad, extended nearly to apex of lobe; ventral appendage arising preapically, extended dorsomesad (broken in holotype); lobe between appendages rounded; ventrolateral setal group with $\sim 5$ enlarged setae. Aedeagus (Figs. 15b, c) with preatrium well developed, shorter than shaft; dorsal apodeme in lateral view strongly broadened dorsally; shaft in lateral view slender, evenly recurved; paired basal processes extended along sides of shaft to gonopore; apex compressed, bluntly rounded in lateral view, without processes; gonopore preapical on posterior surface.

Material examined. Holotype male, MEXICO, Michoacan, Carapan, km 432, 2 October 
1941 (DeLong, Good, Caldwell); 1 male paratype, same data [INHS].

Notes. This species resembles Z. munda in coloration, but has the aedeagal shaft in lateral view more slender and rounded rather than angulate apically. The species name, an adjective, refers to the type locality.

\section{Zyginama tripunctata (Beamer) (Figs. 2P,} 16)

Erythroneura tripunctata Beamer, 1929b: 119

Zygina tripunctata, Young, 1952:76

Zyginama tripunctata, Dietrich \& Dmitriev, 2006:150

Type locality: Oak Creek Canyon, Arizona [KU].

Distribution: USA: Arizona, Florida, Texas. Notes: Length of male $3.4 \mathrm{~mm}$, female 3.7 $\mathrm{mm}$. Specimens from Florida, collected on Quercus myrtifolia [INHS] and identified as this species, are much paler overall than those from the southwestern USA but are considered to be conspecific because of the very similar male genitalia. This is the only species of the genus recorded from Florida.

\section{Zyginama coahuilensis, n. sp. (Figs. 2Q,} 17)

Description. Length of male $3.4 \mathrm{~mm}$. Dull yellow overall, crown with pair of brown preapical spots and median apical spot, midline brown; pronotum with pair of submedial Jshaped red maculae; mesonotal triangles bright yellow; forewing with broad red streak in basal half of clavus and another in brachial cell.

Head (Fig. 2Q) narrower than pronotum, crown in dorsal view with median length distinctly greater than length next to eye, anterior margin forming $90^{\circ}$ angle. Male pygofer (Fig. 17a) with dorsal appendage arising near midlength, long, straight, attenuate, not reaching pygofer apex; ventral process arising at apex, moderately long, slender, gently curved dorsomesad; lobe between appendages rounded, poorly sclerotized; ventrolateral setal group with ca. 4 conspicuous setae. Aedeagus (Figs. 17b, c) with preatrium well developed; shaft strongly compressed, broad and nearly parallel-sided in lateral view, gently curved, posterior margin minutely serrate, rounded near apex; pair of short triangular lateral projections just distad of gonopore; subbasal processes slender, extended two-thirds distance to shaft apex, slightly diver- gent in posterior view; gonopore preapical on posterior surface.

Material examined. Holotype male, MEXICO, Coahuila, Saltillo, 23 September 1941 (DeLong, Good, Caldwell, Plummer) [INHS].

Notes. This species resembles Z. tripunctata in coloration, but differs in having the aedeagal shaft broader in lateral view with a pair of small distal projections and the subbasal processes more slender. The species name, an adjective, refers to the type locality.

\section{Zyginama orizaba, n. sp. (Figs. 2R, 18)}

Description. Length of male $3.3 \mathrm{~mm}$. Ground color pale yellow; head with small brown apical spot, crown with orange medial patch posteriorly; pronotum with pair of posteriorly divergent orange streaks; mesonotal triangles brown; scutellum apex black; forewing clavus with basal and medial orange spot, brachial cell with basal and medial red patch, vein $M$ with three red areas alternating with those of brachial cell; apical cells and areas adjacent to costal plaque infused with brown; abdominal terga brown. Head (Fig. 2R) narrower than pronotum; crown in dorsal view distinctly longer medially than next to eye, anterior margin forming $90^{\circ}$ angle. Male pygofer (Fig. 18a) with dorsal appendage arising near base, weakly elevated at base, bent posteroventrad, attenuate, extended to apex of lobe; ventral appendage arising at apex, short, extended posterodorsad; lobe between appendages rounded; ventrolateral setal group with $\sim 5$ enlarged setae. Aedeagus (Figs. 18b, c) without preatrium; dorsal apodeme in lateral view broadened dorsally; shaft slender, nearly straight; subbasal paired processes extended along sides of shaft to near gonopore, divergent from midlength in posterior view; preapical processes, broad, triangular, extended anterad; distal lobe compressed, bent at right angle to shaft, apex acute; gonopore preapical on posterior surface.

Material examined. Holotype male, MEXICO, Veracruz, Orizaba, km 260, 17 October 1941 (DeLong, Good, Caldwell, Plummer) [INHS].

Notes. This species resembles Z colima in coloration but is readily distinguished by the elongate dorsal pygofer appendage and the rectangularly bent distal lobe of the aedeagus. The species name, an adjective, refers to the type locality. 
17. Zyginama rodmani, n. sp. (Figs. 2S, 19)

Description. Length of male $3.9 \mathrm{~mm}$. Ground color off white; face with apex of anteclypeus and antennal pit brown, with pair of small orange spots adjacent to eyes and median hourglass-shaped orange macula extended onto crown; crown with pair of orange blotches, each with obscure brown spot; pronotum with anterior margin broadly bordered with cream interrupted by submedian and lateral pairs of orange maculae; mesonotal triangles brown; scutellum apex brown; forewing clavus and discal cells with large irregular but symmetrical reddish blotches; meso- and metathoracic sterna and abdomen mostly brown. Head (Fig. $2 \mathrm{~S})$ narrower than pronotum; crown in dorsal view distinctly longer medially than next to eye, anterior margin forming $90^{\circ}$ angle. Male pygofer (Fig. 19a) with dorsal appendage arising in basal half, attenuate, not elevated above pygofer margin, extended nearly to apex of lobe; ventral appendage arising near apex, short, extended dorsomesad; lobe between appendages rounded; ventrolateral setal group with $\sim 4$ enlarged setae. Aedeagus (Figs. 19b, c) without preatrium; in lateral view with dorsal apodeme broadened dorsad; shaft compressed, broadened and obliquely rounded apically; paired subbasal processes closely appressed to each other and little divergent from shaft, extended $2 / 3$ distance to shaft apex; apex in posterior view acute with pair of short obtusangular preapical lateral flanges; gonopore preapical on posterior surface.

Material examined. Holotype male, MEXICO, 50 km E Mexico City, 29 December 1949 (R.H. Beamer) [OSU].

Note. This species is the only known $Z y$ ginama species whose color pattern includes numerous red flecks on the forewing. Other distinctive features include its large size and aedeagus with the apex expanded and broadly expanded in lateral view. The species is named in honor of Dr. James E. Rodman to recognize his advocacy and promotion of the science of systematic biology through many years of outstanding service as Program Director in the Division of Environmental Biology, National Science Foundation, Washington, DC, USA.

18. Zyginama malleta, n. sp. (Figs. 2T, 20) Description. Length of male $3.5 \mathrm{~mm}$ (approximate). Ground color dull yellow; markings of head unknown (head missing in holotype); pronotum with brown spot near midlength of lateral margin; mesonotal triangles brown; apex of scutellum black; thoracic sterna and abdominal segments mostly brown; forewing infused with brown, with dull yellow streaks along longitudinal veins. Male pygofer (Fig. 20a) with dorsal appendage arising in basal half, slightly elevated above margin of lobe at base, elongate, slender, curved ventrad, apex blunt, not reaching apex of lobe; ventral appendage arising preapically, moderately long, curved dorsomesad; lobe between appendages rounded; ventrolateral setal group with $\sim 5$ enlarged setae. Aedeagus (Figs. 20b, c) with preatrium short; dorsal apodeme in lateral view narrow, slightly expanded dorsad; shaft compressed, in lateral view moderately broad, with pair short triangular projections on dorsal margin near base; subbasal processes extended along sides of shaft $2 / 3$ distance to apex, curved slightly posterad, divergent in posterior view; apex in lateral view with quadrate anterior lobe and clawlike posterior projection; gonopore apical. Material examined. Holotype male, MEXICO, Michoacan, Carapan, km 432, 2 October 1941 (DeLong, Good, Caldwell, Plummer) [INHS].

Notes. This species resembles $Z$. tripunctata in coloration, but is readily distinguished by the distinctive hammerlike aedeagal apex, upon which the species name, an adjective, is based.

\section{Zyginama zitacuarensis, n. sp. (Figs. 2U,} 21)

Description. Length of male $3.4 \mathrm{~mm}$. Ground color pale yellow; head unmarked; pronotum with pair of orange submedial stripes bent laterad posteriorly; mesonotal triangles pale orange; scutellum apex black; forewing clavus with broad orange longitudinal stripe, corium with orange stripe along vein $\mathrm{Cu}$. Head (Fig. $2 \mathrm{~T}$ ) narrower than pronotum; crown in dorsal view distinctly longer medially than next to eye, anterior margin acutely angled. Male pygofer (Fig. 21a) with dorsal appendage arising in basal half, not elevated above margin of lobe, attenuate, curved slightly ventrad, extended nearly to apex of lobe; ventral appendage arising at apex, short, curved posterodorsad; lobe between appendages rounded; ventrolateral setal group with $\sim 5$ enlarged setae. Aedeagus (Figs. 21b, c) without preatrium; dorsal apodeme in lateral view expanded dorsally; shaft compressed, in lateral view nearly straight, 
with pair of triangular processes dorsally near midlength, posterior margin irregularly serrate preapically, with preapical constriction; paired subbasal processes extended along sides of shaft $2 / 3$ distance to apex, divergent in posterior view; distal processes absent; apical lobe subquadrate; gonopore preapical on posterior surface.

Material examined. Holotype male, MEXICO, Michoacan, Zitacuaro, 29 September 1941 (DeLong, Good, Caldwell, Plummer) [INHS].

Notes. This species resembles $Z$. vittata in coloration, but differs in having the scutellum black apically. The aedeagus resembles that of $Z$. rodmani, but differs in having a pair of dorsal preapical triangular processes and the apex no wider in lateral view than the width of the shaft at midlength. The species name, an adjective, refers to the type locality.

20. Zyginama rubrocta, n. sp. (Figs. 2V, 22) Description. Length of male $3.3 \mathrm{~mm}$. Ground color pale yellow; crown red except along anterior margin; pronotum with broad red transverse band extended onto pleuron; mesonotum and scutellum red; forewing base red, with large nearly circular red transcommisural marking near midlength with anterior and posterior extensions to costal margin; mesosternum and abdominal terga dark brown. Head (Fig. $2 \mathrm{~V}$ ) narrower than pronotum, crown in dorsal view strongly produced medially, apex acutely angular. Male pygofer (Fig. 22a) with dorsal appendage arising near midlength, base slightly elevated above margin of lobe, acuminate, distal half bent ventrad, extended to apex of lobe; ventral appendage arising preapically, long, curved dorsomesad; lobe between appendages rounded; ventrolateral setal group with $\sim 6$ slightly enlarged setae. Aedeagus (Figs. $22 \mathrm{~b}, \mathrm{c}$ ) without preatrium; dorsal apodeme in lateral view slightly broadened dorsally; shaft in lateral view slender, slightly sinuate, with large unpaired basal process extended slightly beyond midlength and slightly divergent from shaft; paired distal processes arising basad of gonopore, slender, extended ventrad then curved anterad; apical lobe compressed, apex rectangular; gonopore preapical on posterior surface.

Material examined. Holotype male,

MEXICO, Chiapas, Finca Prusia, 4 December 1932 (M.F. 2872) [INHS].

Notes. This species closely resembles Z. iguala in coloration and in the form of the aedeagus, but differs in having the pygofer dorsal appendage abruptly bent ventrad near its midlength and in lacking a posterior preapical spine on the aedeagus. The species name, an adjective, was formed by combining "rubr-" meaning "red" with "octa" meaning "eight" and refers to the eight red markings on the dorsum of this species.

\section{Zyginama iguala (Ross) (Figs. 2W, 23) \\ Erythroneura iguala Ross, 1965a: 263 \\ Zyginama iguala, Dietrich \& Dmitriev, 2006:150 \\ Type locality: Iguala, Guerrero, Mexico} [OSU].

Distribution. MEXICO: Guerrero.

Notes: Length of male $2.8 \mathrm{~mm}$, female $3.0 \mathrm{~mm}$.

22. Zyginama novella (Knull \& Auten) (Figs.

2X, 24)

Erythroneura novella Knull \& Auten, 1938a:536

Zygina novella, Young, 1952:76

Zyginama novella, Dietrich \& Dmitriev, 2006:150

Type locality: Chiricahua Mts., Arizona

[OSU].

Distribution: USA: Arizona.

Notes: Length of male $3.0 \mathrm{~mm}$, female $3.1 \mathrm{~mm}$.

23. Zyginama arizonica (Knull \& Auten) (Figs. 2Y, 25)

Erythroneura arizonica Knull \& Auten, 1938a:536

Zygina arizonica, Young, 1952:76

Zyginama arizonica, Dietrich \& Dmitriev, 2006:149

Type locality: Huachuca Mts., Arizona [OSU]. Distribution: USA: Arizona.

Notes: Length of male $3.3 \mathrm{~mm}$, female 3.8 $\mathrm{mm}$.

24. Zyginama elongata, n. sp. (Figs. 2Z, 26)

Description. Length of male 3.3-3.4 mm.

Ground color pale yellow; face pale, unmarked; crown with small apical brown spot; pronotum with pair of sublateral brown spots and large submedial triangles, posterior margin white; mesonotum with three longitudinal brown stripes; scutellum apex black; forewing clavus with orange longitudinal stripe constricted medially, brachial cell mostly orange in distal twothirds, costal cell yellow in basal two-thirds, 
hyaline distally; mesosternum and abdomen except subgenital plates brown. Head (Fig. 2Z) narrower than pronotum; crown in dorsal view distinctly longer medially than next to eye, anterior margin forming $90^{\circ}$ angle. Male pygofer (Fig. 26a) with dorsal appendage arising near base, acute, nearly straight, not elevated above pygofer margin, extended slightly beyond midlength of lobe; ventral appendage arising at apex of lobe, short, curved dorsomesad; lobe between appendages rounded; ventrolateral setal group with $\sim 6$ enlarged setae. Aedeagus (Figs. 26b, c) without preatrium; in lateral view with dorsal apodeme slightly broadened dorsally; shaft in lateral view nearly straight, slender, broadened distally; paired subbasal processes extended beyond shaft midlength, slightly divergent from each other and from shaft; pair of elongate slender apical processes extended ventrolaterad with apices curved posterad; apex compressed, in lateral view rounded with anterior margin angled, notched posteriorly at gonopore; gonopore preapical on posterior surface.

Material examined. Holotype male, MEXICO, Morelos, 10 km N Cuernavaca, 28 December 1948 (R.H. Beamer) [OSU].

Notes. This species resembles Z. aucta in coloration but differs in having the aedeagus with paired basal and distal processes and the shaft apex broadened apically in lateral view. The species name, an adjective, refers to the elongate form of the body.

\section{Zyginama enigmata, n. sp. (Figs. 2AA, 27)}

Description. Length of male $3.5-3.7 \mathrm{~mm}$, female $3.9 \mathrm{~mm}$. Ground color pale yellow; face dull yellow medially, pale laterally; crown with pair of very diffuse brown preapical spots; pronotum dull yellow with arc of three pale blotches along anterior and lateral margins; posterior margin white; mesonotal triangles dull yellow; scutellum apex black; forewing mostly dull yellow with obscure fuscous markings, claval suture bordered with white; abdominal tergites brown. Head (Fig. 2AA) narrower than pronotum; crown in dorsal view distinctly longer medially than next to eye, anterior margin forming $90^{\circ}$ angle. Male pygofer (Fig. 27a) with dorsal appendage arising in basal half, elevated above margin of lobe basally, curved ventrad then posterad and terminating in bluntly rounded tip, not reaching apex of lobe; ventral appendage arising preapically, long, curved dorsomesad; lobe between appendages rounded; ventrolateral setal group with 1 enlarged seta. Aedeagus (Figs. 27b, c) with preatrium nearly as long as shaft; dorsal apodeme in lateral view short and broadly rounded; shaft in lateral view broad, compressed, arched posterodorsad; paired subbasal processes shorter than shaft, strongly divergent from shaft and each other; paired distal processes arising basad of gonopore, short, spinelike, extended basolaterad; apex compressed, abruptly bent dorsad; gonopore preapical on posteroventral surface.

Material examined. Holotype male, MEXICO, 50 km E Mexico City, 29 December 1949 (R.H. Beamer) [OSU]; 1 male and 2 female paratypes, same data [OSU].

Notes. This species resembles Z. pinalensis, $Z$. inornata, and $Z$. brunnedorsum in having the preatrium of the aedeagus elongate and the shaft broad and arcuate in lateral view, but differs in having a pair of large processes arising near the base of the shaft on the ventral side. The species name, an adjective, refers to the enigmatic shape of the aedeagus.

\section{Zyginama queretarensis, n. sp. (Figs. 2BB,} 28)

Description. Length of male $3.3 \mathrm{~mm}$. Coloration similar to that of $Z$. coahuilensis, but brown spots larger and J-shaped maculae of pronotum broader and fused medially. Head (Fig. 2BB) narrower than pronotum; crown in dorsal view distinctly longer medially than next to eye, anterior margin forming obtuse angle.

Pygofer (Fig. 28a) with dorsal appendage arising near midlength, not elevated above margin of lobe, short, broad, bent posteroventrad near midlength, apex blunt, not reaching apex of lobe; ventral appendage arising preapically, short, slender, extended dorsomesad; lobe between appendages rounded; ventrolateral setal group with $\sim 4$ enlarged setae. Aedeagus (Figs. $28 \mathrm{~b}, \mathrm{c})$ with preatrium short; dorsal apodeme in lateral view broadened dorsally; shaft in lateral view, broad basally, abruptly narrowed from midlength to apex; with pair of rounded lateral subbasal flanges; with paired subbasal processes short, weakly divergent, extended slightly past midlength of shaft; paired distal processes arising adjacent to gononpore, somewhat flattened with obtusangular projection subbasally, curved ventrolaterad; apex compressed bent dorsad, obliquely rounded at tip; gonopore apical. 
Material examined. Holotype male, MEXICO: Queretaro, Solis, 20 May 1928 (M.F. 1334) [INHS].

Notes. This species closely resembles $Z$. tripunctata in coloration, but differs in its distinctive male genitalia, including the bluntly rounded and ventrally bent dorsal pygofer appendage and the unique shape of the aedeagal apex. The species name, an adjective, refers to the Mexican state in which the holotype was collected.

\section{Zyginama obscura (Beamer) (Figs. 2CC,} 29)

Erythroneura obscura Beamer, 1929b: 117

Zygina obscura, Young, 1952:76

Zyginama obscura, Dietrich \& Dmitriev, 2006:150

Type locality: Huachuca Mts., Arizona [KU].

Distribution: USA: Arizona.

Notes: Length of male $3.5 \mathrm{~mm}$, female $3.8 \mathrm{~mm}$.

28. Zyginama angulata, n. sp. (Figs. 2DD, 30)

Description. Length of male $3.3 \mathrm{~mm}$. Ground color dull yellow; face brown except near dorsal margin; crown white with pair of diffuse orange submedial spots; pronotum with orange submedial triangles, posterior margin white; mesonotal triangles orange; scutellum apex black; forewing pale with orange longitudinal stripe in clavus and another along vein $\mathrm{Cu}$; mesosternum and abdomen mostly dark brown. Head (Fig. 2DD) narrower than pronotum; crown in dorsal view distinctly longer medially than next to eye, anterior margin forming $90^{\circ}$ angle. Male pygofer (Fig. 30a) with dorsal appendage arising near midlength, not elevated above margin of lobe, short, tapered to acute apex, curved ventrad, not extended to apex of lobe; ventral appendage apical, very short, toothlike; lobe between appendages rounded; ventrolateral setal group with $\sim 4$ enlarged setae. Aedeagus (Figs. 30b, c) without preatrium; dorsal apodeme in lateral view slender, slightly broadened dorsally; shaft in lateral view slender, slightly sinuate; paired subbasal processes elongate, slightly divergent from shaft, parallel to each other, extended to near gonopore; paired distal processes arising at apex, lamelliform with three branches, ventral pair arising from common stem and strongly divergent; gonopore apical.

Material examined. Holotype male,
MEXICO, Distito Federal, Mexico City, Toluca Rd, 26 September 1945 (collector unknown) [INHS].

Notes. This species resembles Z triceroprocta externally, but is readily distinguished by the very short ventral pygofer appendage and the distinctive, three-branched distal processes of the aedeagus. The species name, an adjective, refers to the angulate aedeagal processes.

29. Zyginama durangensis, n. sp. (Figs. 3A, 31) Description. Length of male $2.9 \mathrm{~mm}$. Ground color pale yellow; face without distinct markings; crown with weak pair of brown preapical spots and pair of longitudinal orange stripes extended onto pronotum and bent laterad near posterior margin at a $90^{\circ}$ angle; mesonotal triangles pale orange; scutellum apex black; forewing veins orange, cells white; clavus with broad longitudinal orange stripe. Head (Fig. 3A) narrower than pronotum; crown in dorsal view distinctly longer medially than next to eye, anterior margin forming $90^{\circ}$ angle. Male pygofer (Fig. 31a) with dorsal appendage arising in basal half, slightly elevated above margin of lobe, acuminate, curved ventromesad, not extended to apex of lobe; ventral appendage arising preapically, short, curved dorsad; lobe between appendages rounded ventrolateral setal group with $\sim 3$ enlarged setae. Aedeagus (Figs. $31 \mathrm{~b}, \mathrm{c}$ ) without preatrium; dorsal apodeme in lateral view broadened dorsally; shaft compressed, in lateral view moderately broad, nearly straight, with pair of small dorsal basolateral lobes; subbasal paired processes weakly divergent from shaft in lateral view, extended to near gonopore; distal paired processes broad, lamelliform, with acuminate anteriorly directed apices; apex in lateral view slender, curved anterad, truncate, compressed; gonopore preapical on posterior surface.

Material examined. Holotype male, MEXICO, Durango, rt. $40 \mathrm{~km} 946.3 \mathrm{~km}$ E El Salto, $23.83578^{\circ} \mathrm{N}, 105.32608^{\circ} \mathrm{W}, 2500 \mathrm{~m}, 26$ October 2005 (C.H. Dietrich) [INHS].

Notes. This species resembles Z. agnata in coloration and the structure of the male genitalia, but differs in having the distal processes of the aedeagus lamelliform and the shaft with a pair of short keels dorsally near the base. The species name, an adjective, refers to Mexican state in which the holotype was collected.

\section{Zyginama unicolor (Beamer) (Figs. 3B, 32) Erythroneura unicolor Beamer, 1929b:120}


Zygina unicolor, Young, 1952:76

Zyginama unicolor, Dietrich \& Dmitriev, 2006:150

Type locality: Culberson Co., Texas [KU].

Distribution: USA: Texas.

Notes: Length of male $3.3 \mathrm{~mm}$, female 3.5

$\mathrm{mm}$. Beamer's holotype [KU], the only known male of this species, has the genitalia dissected and mounted on a slide.

31. Zyginama sola (Knull \& Auten) (Figs. 3C, 33)

Erythroneura sola Knull \&Auten, 1938a:

534

Zygina sola, Young, 1952:76

Zyginama sola, Dietrich \& Dmitriev, 2006:150

Type locality: Chiricahua Mts., Arizona [OSU].

Distribution: USA: Arizona.

Notes: Length of male $3.5 \mathrm{~mm}$, female 3.7 mm. Knull and Auten (1938a) recorded oak as the host plant.

\section{Zyginama cornigera (Beamer) (Figs. 3D,} 34)

Erythroneura cornigera Beamer, 1937b: 31

Zygina cornigera, Young, 1952:75

Zyginama cornigera, Dietrich \& Dmitriev, 2006:149

Type locality: Strawberry, California [KU].

Distribution: USA: California.

Notes: Length of male $3.0 \mathrm{~mm}$, female

$3.1 \mathrm{~mm}$. This is the only known species of Zyginama that lacks a ventral pygofer appendage. Unlike species of other New World genera that lack this appendage, Z. cornigera has the ventolateral margin of the pygofer strongly sclerotized, suggesting a vestigial condition. As noted by Beamer (1937b) the apical processes of the aedeagus may be branched (as in the photo published by Beamer) or unbranched (as in Figs. 4T, U).

\section{Zyginama erosa (McAtee) (Figs. 3E, 35)} Erythroneura erosa McAtee, 1924c: 36 Zygina erosa, Young, 1952:76 Zyginama erosa, Dietrich \& Dmitriev, 2006:150

Type locality: Folsom, California [USNM].

Distribution: USA: California.

Notes: Length of male $2.8 \mathrm{~mm}$, female 3.0 $\mathrm{mm}$. The only known male specimens of this species, in Beamer's collection (KU), have the genitalia mounted on slides. Beamer (1932i) recorded this species from "live oaks".

34. Zyginama casta (Beamer) (Figs. 3F, 36) Erythroneura casta Beamer, 1929b:118 Zygina casta, Young. 1952:75 Zyginama casta, Dietrich \& Dmitriev, 2006:149

Type locality: Huachuca Mts. [east side of Car Peak near top], Arizona [KU].

Distribution: USA: Arizona.

Notes: Length of male $2.9 \mathrm{~mm}$, female 3.3 $\mathrm{mm}$. Beamer (1929b) recorded this species from "short, scrubby oaks".

35. Zyginama agnata (Knull \& Auten) (Figs. $3 \mathrm{G}, 37$ )

Erythroneura agnata Knull \& Auten, 1938a:537

Zygina agnata, Young, 1952:76

Zyginama agnata, Dietrich \& Dmitriev, 2006:149

Type locality: Huachuca Mts., Arizona [OSU]. Distribution: USA: Arizona.

Notes: Length of male $2.8 \mathrm{~mm}$, female 3.0 $\mathrm{mm}$.

36. Zyginama panamensis, n. sp. (Figs. 3H, 38) Description. Length of male $3.7 \mathrm{~mm}$. Ground color pale yellow; head and pronotum without distinct markings; mesonotal triangles pale orange; scutellum apex black; forewing clavus with indistinct basal and medial male orange spots, costal area pale orange infused with brown, apical cells infused with brown. Head (Fig. 3H) narrower than pronotum; crown in dorsal view distinctly longer medially than next to eye, anterior margin forming $90^{\circ}$ angle. Male pygofer (Fig. 38a) with dorsal appendage arising near base, not elevated above margin of lobe, attenuate, curved ventrad, extended slightly beyond midlength of lobe; ventral appendage arising at apex, moderately long, curved dorsomesad; lobe between appendages subquadrate; ventrolateral setal group with $\sim 3$ enlarged setae. Aedeagus (Figs. 38b, c) with preatrium short; dorsal apodeme in lateral view strongly expanded dorsally; shaft short, compressed, nearly straight, with short retrorse spine on dorsal margin near midlength; with single short asymmetrical process arising just basad of gonopore and curved ventrolaterad; paired processes absent; distal lobe com- 
pressed, bluntly rounded; gonopore preapical on posterior surface.

Material examined. Holotype male, PANAMA: Chiriqui Pr., $4 \mathrm{~km}$ E Boquete Valle Palo Alto, 8'48'33”N, 82 $23^{\circ}$ '59'W, 29 July 1999 (J. Shaffner) [TAMU].

Notes. This species resembles $Z$. colima in coloration but is paler overall and has distinctive male genitalia: the aedeagus has a retrorse preapical dorsal spine and an asymmetrical posterior preapical spine. The species name, an adjective, refers to the country in which the holotype was collected. This is the only Zyginama species recorded from Panama.

37. Zyginama colima, n. sp. (Figs. 3I, 39)

Description. Length of male $4.2 \mathrm{~mm}$. Ground color pale yellow; head with small median brown apical spot, crown with pair of obscure orange submedial spots; pronotum with pair of orange submedial spots posteriorly; mesonotal triangles pale orange; scutellum apex black; forewing clavus with basal and medial orange maculae, corium with orange maculae at midlength and apex of brachial cell. Head (Fig. 3I) narrower than pronotum, crown in dorsal view with median length distinctly greater than length next to eye, anterior margin forming $90^{\circ}$ angle. Male pygofer (Fig. 39a) with dorsal appendage arising near midlength, not elevated above margin of lobe, long, acuminate, curved slightly ventrad, extended to apex of lobe, with long slender spine arising laterally near midlength and curved slightly dorsad; ventral appendage arising preapically, long, curved dorsomesad; ventrolateral setal group with $\sim 8$ enlarged setae. Aedeagus (Figs. 39b, c) with preatrium very short; dorsal apodeme in lateral view expanded dorsally; shaft in lateral view slender, irregularly recurved, with pair of short triangular processes on dorsal margin near midlength and pair of short rounded processes ventrolaterally near base; posterior margin with serrate median flange; apical lobe compressed, digitiform in lateral view; gonopore preapical on posterior margin.

Material examined. Holotype male, MEXICO: Jalisco, rd. to Parque Nacional de Volcan de Colima 11 mi. W hwy. junct. 54 (near Atenquique), 11-12 July 1984 (Carroll, Schaffner, Friedlander) [TAMU].

Notes. This species is similar to Z. erosa in coloration, but is readily distinguished by the elongate spine on the dorsal pygofer appendage and the lack of paired processes on the aedeagus. The species name, an adjective, refers to the type locality.

38. Zyginama lanceolata, n. sp. (Figs. 3J, 40) Description. Length of male $3.7 \mathrm{~mm}$, female $3.9 \mathrm{~mm}$. Ground color pale yellow; head and pronotum without distinct markings; mesonotum and scutellum brown; forewing clavus with bright red transcommisural ellipse, costal margin with brown macula just distad of brochosome field. Head (Fig. 3J) narrower than pronotum; crown in dorsal view distinctly longer medially than next to eye, anterior margin forming $90^{\circ}$ angle. Male pygofer (Fig. 40a) with dorsal appendage arising near midlength, base not elevated above margin of lobe, acuminate, curved dorsomesad, not extended to apex of lobe; ventral appendage arising at apex, very short; lobe between appendages shallowly concave; ventrolateral setal group conspicuous, but setae not enlarged. Aedeagus (Fig. 40b) without preatrium; dorsal apodeme short; shaft in lateral view straight, compressed, without paired processes, with short retrorse spine near midlength; apex acute, compressed, with short projection just basad of gonopore; gonopore preapical on posterior surface.

Material examined. Holotype male, MEXICO, 50 km E Mexico City, 29 December 1949 (J.G. Shaw) [OSU].

Notes. This species has a prominent orange macula on the forewing clavus similar to that of $Z$. ritana, but differs in having the mesonotum and scutellum entirely dark brown and in the distinctive lanceolate aedeagus, upon which the species name, an adjective, is based.

39. Zyginama tricolor (Beamer) (Figs. 3K, 41) Erythroneura tricolor Beamer, 1929b: 124 Zygina tricolor, Young, 1952:76 Zyginama tricolor, Dietrich \& Dmitriev, 2006:150

Type locality: Huachuca Mts. [east side of Car Peak], Arizona [KU].

Distribution: MEXICO: Distrito Federal.

USA: Arizona.

Notes: Length of male $3.0 \mathrm{~mm}$, female 3.2

$\mathrm{mm}$. Beamer (1929b) recorded oak as the host.

40. Zyginama tolteca, n. sp. (Figs. 3L, 42)

Description. Length of male $3.2 \mathrm{~mm}$, female $3.3 \mathrm{~mm}$. Ground color dull yellow. Face dark 
brown except dorsal margin; crown white with small apical spot and large posterior submarginal blotch orange. Pronotum with pair of lateral submarginal and anterior submedial orange spots in some cases merging with larger median posteior orange area; posteiror margin white. Mesonotal triangles orange-brown; scutellum apex black. Forewing basal twothirds orange red with two large transcommisural white areas in clavus; costal plaque white; apical cells except third smoky. Mesosternum and abdominal terga brown. Head (Fig. 3L) narrower than pronotum; crown in dorsal view distinctly longer medially than next to eye, anterior margin forming $90^{\circ}$ angle. Male pygofer (Fig. 42a) with dorsal appendage arising in basal half, elevated above margin of lobe, nearly straight, acuminate, extended slightly beyond apex of lobe; ventral appendage arising preapically, elongate, curved dorsomesad; lobe between appendages rounded; ventrolateral setal group conspicuous but with setae only slightly enlarged. Aedeagus (Figs. 42b, c) with preatrium well developed, shorter than shaft; dorsal apodeme in lateral view tapered to abruptly broadened apex; shaft recurved, slender, apex compressed, without processes; gonopore preapical on posterior surface.

Material examined. Holotype male, MEXICO, Morelos, $10 \mathrm{~km}$ N Cuernavaca, 28 December 1948 (R.H. Beamer) [OSU]; 1 female paratype, same data [OSU].

Notes. This species resembles Z. olmeca in coloration but has the orange bands and spots more broken and irregular, the dorsal appendage of the pygofer nearly straight, and the aedeagal shaft lacking paired processes. The species name, an adjective, is based on that of the Toltec pre-Columbian culture of Mexico.

\section{Zyginama nuda (Knull \& Auten) (Figs. 3M,} 43)

Erythroneura nuda Knull \& Auten, 1938a:538

Zygina nuda, Young, 1952:76

Zyginama nuda, Dietrich \& Dmitriev, 2006:150

Type locality: Santa Rita Mts., Arizona [OSU]. Distribution: USA: Arizona.

Note: Length of male $3.0 \mathrm{~mm}$, female $3.4 \mathrm{~mm}$. The holotype [OSU] is the only known male. The genitalia are mounted on a slide and appear to be damaged.
42. Zyginama brunnedorsum, n. sp. (Figs. $3 \mathrm{~N}, 44)$

Description. Length of male $3.3 \mathrm{~mm}$, female $3.6 \mathrm{~mm}$. Ground color pale yellow; face bright yellow, without dark markings; dorsum with broad dark brown marking covering entire crown and pronotum except lateral margins, mesonotum and scutellum, and extended obliquely across middle of forewing clavus to costal margin; a second broad oblique brown band extended across distal crossveins. Head (Fig. 3N) narrower than pronotum; crown in dorsal view strongly produced medially, anterior margin forming acute angle. Male pygofer (Fig. 44a) with dorsal appendage arising near midlength, elevated above margin of lobe basally, curved ventrad then posterad, apex acuminate, not extended to apex of lobe; ventral appendage arising apically, moderately long, curved dorsomesad; lobe between appendages rounded; ventrolateral setal group conspicuous but setae not enlarged. Aedeagus (Figs. 44b, c) with preatrium well developed, shorter than shaft; dorsal apodeme in lateral view broadly rounded; shaft in lateral view broad, compressed, arched posterodorsad; without subbasal processes; paired spines arising on dorsal margin slightly beyond midlength and extended basad along shaft; pair of apical processes arising near apex ventrad of gonopore; pair of short triangular flanges on ventral margin just basad of gonopore; apex in lateral view with slender process extended dorsad at right angle to shaft and distal process arising ventrad of gonopore and extended distad; gonopore apical.

Material examined. Holotype male, MEXICO, 50 km E Mexico City, 29 December 1949 (R.H. Beamer); 1 male and 1 female paratype, same data [OSU].

Notes. The color pattern of this species, which resembles that of the temperate North American erythroneurine species Erythridula juglandacea (Ross \& DeLong), is unique among known Zyginama spp. The aedeagus resembles that of $Z$. pinalensis but differs in having the distal spine straight and the ventroapical processes extended posteroventrad. The species name, a noun in apposition, refers to the brown coloration of the dorsum.

\section{Zyginama pinalensis (Beamer) (Figs. 3O, 45)}

Erythroneura pinalensis Beamer, 1929b: 119 
Zygina pinalensis, Young, 1952:76 Zyginama pinalensis, Dietrich \& Dmitriev, 2006: 150

Type locality: Pinal Co., Arizona [KU].

Distribution. USA: Arizona.

Notes: Length of male $2.8 \mathrm{~mm}$, female 3.0 $\mathrm{mm}$.

\section{Zyginama triceroprocta (Beamer) (Figs. 3P, 46)}

Erythroneura triceroprocta Beamer, 1929b:118

Zygina triceroprocta, Young, 1952:76

Zyginama triceroprocta, Dietrich \& Dmitriev, 2006:150

Type locality: Culberson Co., Texas [KU].

Distribution: USA: Texas.

Notes: Length of male $3.2 \mathrm{~mm}$, female $3.5 \mathrm{~mm}$.

\section{Zyginama multifurca, n. sp. (Figs. 3Q, 47)}

Description. Length of male $3.7 \mathrm{~mm}$, female $3.5 \mathrm{~mm}$. Ground color dull yellow; face pale, unmarked; crown with median apical and pair of preapical brown spots; pronotum with indistinct pair of orange submedial triangles, posterior margin white; mesonotal triangles orange; scutellum apex black; forewing hyaline with longitudinal yellow-orange stripe in clavus and another along vein $\mathrm{Cu}$; mesosternum and abdominal tergites brown. Head (Fig. 3Q) narrower than pronotum; crown in dorsal view distinctly longer medially than next to eye, anterior margin forming $90^{\circ}$ angle. Male pygofer (Fig. 47a) with dorsal appendage arising near midlength, short, broad, elevated slightly above margin of lobe, apex shallowly bifid with preapical ventral spine, not extended to apex of lobe; ventral appendage arising preapically, short, curved dorsomesad; lobe between appendages rounded; ventrolateral setal group with $\sim 8$ enlarged setae. Aedeagus (Figs. 47b, c) without preatrium; dorsal apodeme in lateral view slender, nearly parallel-sided; shaft in lateral view slender, elongate, recurved, broadened preapically; subbasal processes absent; paired distal processes slender, flattened, forked preapically with ventral branch shorter than dorsal, curved ventrolaterad then anterad; apex in lateral view attenuate with blunt tip, in posterior view trifurcate; gonopore preapical on posterior margin.

Material examined. Holotype male, MEXICO, 50 km E Mexico City, 29 December 1949 (R.H. Beamer) [OSU]; 2 female paratypes, same data.
Notes. This species resembles Z. tripunctata in coloration, but is readily distinguished by the male genitalia. The dorsal pygofer appendage is broad and tridentate, and the aedeagus is also tridentate distally with a pair of bifid preapical processes. The species name, an adjective, refers to the forked aedeagal processes.

\section{Zyginama colorada, n. sp. (Figs. 3R, 48)}

Description. Length of male $3.6 \mathrm{~mm}$. Ground color pale yellow with obscure orange markings; forewing veins orange, cells white; clavus with broad longitudinal orange stripe. Head (Fig. 3R) narrower than pronotum; crown in dorsal view distinctly longer medially than next to eye, anterior margin forming $90^{\circ}$ angle. Male pygofer (Fig. 48a) with dorsal appendage arising in basal half, elevated above margin of lobe, acuminate, curved ventrad then posterad, not extended to apex of lobe; ventral appendage arising preapically, long, curved dorsomesad; lobe between appendages rounded; ventrolateral setal group with $\sim 2$ enlarged setae. Aedeagus (Figs. 48b, c) with preatrium well developed, nearly as long as shaft; dorsal apodeme in lateral view broadly rounded; shaft in lateral view straight, slender, compressed, with pair of dorsal subbasal spines and pair of slender preapical processes curved ventrolaterad; apex with elongate digitiform lobe extended posterodorsad and short ventral spine extended ventrad; gonopore apical.

Material examined. Holotype male, USA, Colorado, Green Mt. Falls, el. 8000 ft., 25

August 1954 (Ross and Ross) [INHS]; 1 male paratype labeled "Colorado" [CSU].

Notes. This species closely resembles $Z$. utahna, but differs in having the dorsal pygofer appendage footlike and the aedeagus lacking dorsal preapical spines. The species name, an adjective, refers to the type locality.

\section{Zyginama vittata, n. sp. (Figs. 3S, 49)}

Description. Length of male $3.3 \mathrm{~mm}$. Pale yellow overall, crown without brown spots, with obscure U-shaped orange macula extended onto pronotum; forewing with longitudinal orange vittae on clavus and along vein $\mathrm{Cu}$. Head (Fig. $3 S$ ) slightly narrower than pronotum; crown in dorsal view distinctly longer medially than next to eye, anterior margin forming $90^{\circ}$ angle. Male pygofer (Fig. 49a) with dorsal appendage arising near midlength, slightly elevated above margin of lobe, short, acuminate, bent 
ventrad, not extended to apex of lobe; ventral appendage slender, moderately long, extended dorsomesad; lobe between appendages nearly straight; ventrolateral setal group with $\sim 2$ conspicuous setae. Aedeagus (Figs. 49b, c) with preatrium nearly as long as shaft; dorsal apodeme in lateral view very large, quadrate anteriorly, broadly rounded posteriorly; shaft in lateral view slender, straight; without basal processes; pair of distal processes arising adjacent to gonopore, twisted anterolaterad, bifid apically; apical lobe bent at right angle to shaft, attenuate, tip hooked with pair of short lateral processes; gonopore apical.

Material examined. Holotype male, MEXICO: Michoacan, Uruapan, 1 October 1941 (DeLong, Good, Caldwell, Plummer) [INHS].

Notes. This species resembles $Z$. colorada in coloration and in the male genitalia, but is readily distinguished by the aedeagus, which lacks dorsal preapical spines and an unpaired ventral spine distally, and has the paired distal processes forked distally and the shaft apex strongly hooked in lateral view. The species name, an adjective, refers to the yellow vittae on the crown and forewing.

\section{Zyginama cimarroni (Beamer) (Figs. 3T,} 50)

Erythroneura cimarroni Beamer, 1929b: 119

Zygina cimarroni, Young, 1952:75

Zyginama cimmaroni, Dietrich \& Dmitriev, 2006:149

Type locality: Colfax Co., New Mexico [KU].

Distribution: USA: New Mexico.

Notes: Length of male $3.7 \mathrm{~mm}$, female $3.8 \mathrm{~mm}$.

49. Zyginama inornata (McAtee) (Figs. 3U, 51) Erythroneura inornata McAtee,

1924d:132

Zygina inornata, Young, 1952:76

Zyginama inornata, Dietrich \& Dmitriev, 2006:150

Type locality: Ward, Colorado [USNM].

Distribution: USA: Arizona, Colorado.

Notes: Length of male $3.5 \mathrm{~mm}$, female not seen. The concept of this species follows that of Beamer, who compared his specimens to McAtee's holotype and whose collection contains a male specimen with the genitalia dissected and mounted on a slide [KU]. Beamer (1934c) recorded this species from Ceonothus sp.
50. Zyginama utahna (Beamer) (Figs. 3V, 52)

Erythroneura utahna Beamer, 1937b: 32

Zygina utahna, Young, 1952:76

Zyginama utahna, Dietrich \& Dmitriev, 2006:150

Type locality: Cedar City, Utah [KU].

Distribution: USA: Utah.

Notes: Length of male $3.2 \mathrm{~mm}$, female unknown. The genitalia of the holotype, the only known male, are dissected and permanently mounted on a slide [KU].

\section{Zyginama serrata, n. sp. (Figs. 3W, 53)}

Description. Length of male $4.1 \mathrm{~mm}$. Ground color pale yellow; head apex with small black medial spot; pronotum with pair of obscure yellow submedial spots; forewing with yellow streak near middle of anal vein, short yellow streaks near midlength and apex of vein Cu. Head (Fig. 3W) narrower than pronotum; crown in dorsal view distinctly longer medially than next to eye, anterior margin forming $90^{\circ}$ angle. Male pygofer (Fig. 53a) with dorsal appendage arising in basal half, elevated above and strongly divergent from dorsal margin of lobe, elongate, gradually broadened to irregularly serrate tip, extended well beyond apex of lobe; ventral appendage arising at apex, long, curved dorsomesad; lobe between appendages rounded; ventrolateral setal group inconspicuous. Aedeagus (Figs. 53b, c) with preatrium well developed, slender; dorsal apodeme in lateral view slender, slightly expanded dorsally; shaft strongly compressed, in lateral view very broad, irregularly ovoid; pair of slender processes arising near midlength basad of gonopore and curved slightly anterodorsad; ventral margin flared in posterior view; distal lobe compressed and bluntly rounded; gonopore preapical on posterior surface.

Material examined. Holotype male, MEXICO: Nuevo Leon, 5.5 mi. N La Ascencion, 8 July 1986 (Kovarik, Schaffner) [TAMU]. Notes. This species is most readily distinguished by its distinctive dorsal pygofer appendage, which has a truncate, serrate apex; and by the aedeagus, the shaft of which is very broad and nearly ovoid in lateral view. The species name, an adjective, refers to the serrate apex of the dorsal pygofer appendage.

52. Zyginama spatulata, n. sp. (Figs. 3X, 54)

Description. Length unknown (wings of holotype badly damaged). Ground color pale 
yellow, unmarked except pale yellow longitudinal streak in clavus and along vein $\mathrm{Cu}$ of forewing, abdominal terga brown. Head (Fig. $3 \mathrm{X}$ ) narrower than pronotum; crown in dorsal view distinctly longer medially than next to eye, anterior margin forming $90^{\circ}$ angle. Male pygofer (Fig. 54a) with dorsal appendage arising near midlength, not elevated above margin of lobe, attenuate, sinuately curved posteroventrad, extended nearly to apex of lobe; ventral appendage arising preapically, moderately long, curved posterodorsad; lobe between appendages rounded; ventrolateral setal group with $\sim 2$ enlarged setae. Aedeagus (Figs. 54b, c) with preatrium nearly as long as shaft; dorsal apodeme in lateral view greatly expanded; shaft compressed, moderately narrow in lateral view, nearly straight; subbasal processes absent; distal processes arising anterolaterad of gonopore, short, acute, extended anterolaterad; distal lobe compressed, triangular in lateral view; gonopore preapical on posterior surface.

Material examined. Holotype male, MEXICO, Michoacan, Carapan, km 432, 2 October 1941 (DeLong, Good, Caldwell, Plummer) [INHS]. Notes. This indistinctively marked species is most readily distinguished by the broad triangular apex of the aedeagus, and by the dorsal pygofer appendage which is spatulate distally and upon which the species name, an adjective, is based.

\section{Zyginama ochrescens, n. sp. (Figs. 3Y, 55)}

Description. Length of male $2.8 \mathrm{~mm}$. Ground color dull orange. Crown anterior margin and posterior pronotal margin white. Forewing basal two-thirds orange with large white spot at base of clavus, another at base of corium, and two on costal plaque; distal crossveins bordered in white; apical cells smoky. Head (Fig. $3 \mathrm{Y}$ ) subequal in width to pronotum; crown in dorsal view distinctly longer medially than next to eye, anterior margin forming $90^{\circ}$ angle. Male pygofer (Fig. 55a) with dorsal appendage arising near midlength, elevated above margin of lobe, curved ventromesad, constricted preapically, apex bluntly rounded, extended to apex of lobe; ventral appendage arising at apex, long, curved dorsomesad; lobe between appendages nearly straight; ventrolateral setal group with $\sim 3$ enlarged setae. Aedeagus (Figs. $55 \mathrm{~b}, \mathrm{c}$ ) with preatrium well developed, shorter than shaft; dorsal apodeme in lateral view parallel-sided; shaft slender, tubular, slightly recurved; subbasal processes absent; preapical paired processes slender, extended ventrad and curved slightly anterad; apex in lateral and posterior views attenuate, tip bluntly rounded; gonopore preapical on posterior surface.

Material examined. Holotype male, MEXICO "MF 2576" [OSU].

Notes. The holotype was apparently collected by A. Dampf. His field notes, housed in the C.A. Triplehorn Insect Collection at OSU and associated with the lot number on the holotype read as follows " 31 .V.1932. heat wave, last days without rain. Made on light using 300W bulb and special trap. Suburb of San Jacinta D. F. Mexico City (2240 m), surrounded by gardens and facing vegetable fields. Nearby trees are Fraxinus, Salix, \& Cupressus. Collr. A. Dampf."

This species is readily distinguished by its nearly uniform dull orange coloration and distinctive distally rounded dorsal pygofer appendage. The species name, an adjective, refers to the orange coloration.

\section{Zyginama toluca, n. sp. (Figs. 3Z, 56)} Description. Length of male 4.0-4.2 mm, female 3.8-4.0. Ground color dull yellow. Anteclypeus and lateral margin of frontoclypeus ventrad of antennal pit brown; crown orange medially with apical and pair of preapical brown spots. Pronotum, mesonotum and scutellum orange; scutellum apex black. Forewing basal two-thirds yellow orange; claval suture and median discal cell white; apical cells hyaline. Thoracic venter and abdomen dark brown with margins of sclerites pale. Head (Fig. 3Z) narrower than pronotum; crown in dorsal view distinctly longer medially than next to eye, anterior margin forming $90^{\circ}$ angle. Male pygofer (Fig. 56a) with dorsal appendage arising in basal half, elevated above margin of lobe, acuminate, nearly straight, not extended to apex of lobe; ventral appendage arising at apex of lobe, short, extended dorsomesad; lobe between appendages nearly straight; ventrolateral setal group with $\sim 9$ enlarged setae. Aedeagus (Figs. 56b, c) without preatrium; dorsal apodeme in lateral view strongly broadened dorsally; shaft in lateral view straight through most of length, with medially humped dorsal keel; subbasal processes absent, with rounded lateral subbasal keel; paired distal processes arising adjacent to gonopore, slender, extended slightly ventrolaterad then curved anterodorsad, 
with or without preapical tooth; apex in lateral view hooked anterad, trifurcate in posterior view; gonopore preapical on posterior surface. Material examined. Holotype male, MEXICO: Mexico City, Toluca Rd., 26 October 1945 (collector unknown) [INHS]; 1 female paratype, same data [INHS]; 2 male and 1 female paratytpes, MEXICO, $50 \mathrm{~km}$ E Mexico City, 29 December 1949 (R.H. Beamer) [OSU]; 1 female paratype, MEXICO, Morelos, 10 km N Cuernavaca, 28 December 1948 (R.H. Beamer) [OSU].

Notes. This species has markings similar to those of Z. tripunctata but the dorsal coloration is more orange overall. The aedeagus, with its prominent anterodorsal hump and paired lateral distal flanges, is also distinctive. The species name, a noun in apposition, is based on that of the type locality.

55. Zyginama pallescens, n. sp. (Figs. 3AA, 57) Description. Length of male $3.3 \mathrm{~mm}$. Pale stramineous overall, crown without brown spots, forewing with longitudinal yellow vittae on clavus and along vein $\mathrm{Cu}$. Head (Fig. 3AA) slightly narrower than pronotum; crown in dorsal view distinctly longer medially than next to eye, anterior margin forming $90^{\circ}$ angle. Male pygofer (Fig. 57a) with dorsal appendage arising near midlength, not elevated above margin of lobe, short, acuminate, curved ventrad; ventral appendage arising at apex, short, slender, curved dorsomesad; lobe between appendages rectangular; ventrolateral setal group with $\sim 2$ enlarged setae. Aedeagus (Figs. 57b, c) with preatrium well developed, shorter than shaft; dorsal apodeme in lateral view very large, subquadrate; shaft compressed, in lateral view moderately broad, nearly straight; subbasal processes absent; paired distal processes short, slender, arising adjacent to gonopore, curved anteroventrad; apex truncate in lateral view, bifid in posterior view, two sides compressed; gonopore apical.

Material examined. Holotype male, MEXICO: Michoacan, Carapan, km 432, 2 October 1941 (DeLong, Good, Caldwell, Plummer) [INHS].

Notes. This species is most easily distinguished by the aedeagus, which has the shaft apex distinctly bifid in posterior view with a pair of short slender lateral processes. The species name, an adjective, refers to the pale coloration.
56. Zyginama blanda (Knull \& Auten) (Figs. 3BB, 58)

Erythroneura blanda Knull \& Auten, 1938a:538

Zygina blanda, Young, 1952:76

Zyginama blanda, Dietrich \& Dmitriev, 2006:149

Type locality: Huachuca Mts., Arizona [OSU].

Distribution: USA: Arizona.

Notes: Length of male $3.0 \mathrm{~mm}$, female $3.3 \mathrm{~mm}$.

\section{Zyginama pallenta (Beamer) (Figs. 3CC,} 59)

Erythroneura pallenta Beamer, 1929b:117

Zygina pallenta, Young, 1952:76

Zyginama pallenta, Dietrich \& Dmitriev, 2006:150

Type locality: Oak Creek Canyon, Arizona [KU].

Distribution: USA: Arizona.

Notes: Length of male $3.8 \mathrm{~mm}$, female $3.8 \mathrm{~mm}$.

58. Zyginama olmeca, n. sp. (Figs. 3DD, 60)

Description. Length of male $3.8 \mathrm{~mm}$, female $3.8 \mathrm{~mm}$. Ground color dull yellow. Face with dorsal submarginal brown transverse band extended across eye and thoracic pleuron, continuing along costal margin of forewing. Crown off-white, with large median red-orange spot extended to posterior margin. Pronotum off-white with large median red-orange triangle with narrow part extended to posterior margin. Mesonotum brown except median pale area; scutellum apex black. Forewing mostly reddish in basal two-thirds with large oblique ovoid white area near base and more elongate white area distad; inner and outer apical cells brown, third white. Venter and abdominal terga pale. Head (Fig. 3DD) narrower than pronotum; crown in dorsal view distinctly longer medially than next to eye, anterior margin forming $90^{\circ}$ angle. Male pygofer (Fig. 60a) with dorsal appendage arising in basal half, elevated above margin of lobe, slender, curved ventromesad, not extended to apex of lobe; ventral appendage arising at apex, short, extended mesad; lobe between appendages shallowly concave; ventrolateral setal group with $\sim 3$ enlarged setae. Aedeagus (Figs. 60b, c) without preatrium; dorsal apodeme in lateral view broadened dorsally; shaft in lateral view recurved, compressed in distal half; without subbasal processes; with pair of long slender preapical processes arising basad of gonopore, extended anteroventrad and 
curved dorsad; apex acute; gonopore preapical on posterior surface.

Material examined. Holotype male, MEXICO, Morelos, 10 km N Cuernavaca, 28 December 1948 (R.H. Beamer) [OSU]; 2 female paratypes, same data.

Notes. This species is readily distinguished by its unique color pattern and male genitalia. The species name, an adjective, is derived from that of the Olmec culture, which inhabited southern Mexico from 1200-400 BCE.

59. Zyginama ternaria (Van Duzee) (Fig. 3EE) Erythroneura ternaria Van Duzee, 1924a:232

Zygina ternaria, Young, 1952:76

Zyginama ternaria, Dietrich \& Dmitriev, 2006: 150

Type locality: Mill Creek Canyon, San Bernardino Co., California [CAS].

Distribution: USA: California.

Notes: Length of female $3.4 \mathrm{~mm}$, male unknown. Van Duzee's holotype (Fig. 3EE) is a female. No other specimens are known. The dorsal color pattern, consisting of a pair of bold red subparallel longitudinal stripes extended from the crown to the forewing clavus and converging to the commisural margin distally, will separate it from all other known species. Because the coloration of this species differs considerably from that of all other known New World Erythroneurini, placement of this species in Zyginama must be considered tentative until males are discovered.

\section{South American Species}

The following species will key to (or near) Zyginama in the key to New World genera provided by Dietrich and Dmitriev (2006) but differ considerably from the North American species of the genus in external morphology. As in North American Zyginama species, these South American species have a simple, footlike style apex and well developed dorsal and ventral appendages on the male pygofer, but lack a macroseta at the base of the dorsal pygofer appendage (except $Z$. intermedia, n. sp.) and have the pair of spots on the crown absent or poorly delimited, excluding them from Neozygina Dietrich \& Dmitriev. The only other described South American erythroneurine genera that have a ventral pygofer appendage are Hamagina Dietrich \& Dmitriev and Spinigina Dietrich \& Dmitriev, but Hamagina species have an unpaired dorsal process between the base of the aedeagus and the gonopore-bearing shaft, and Spinigina species have the first segment of the male anal tube spinose. Nevertheless, in the structure of the head (not or only weakly produced and as wide or wider than the pronotum) and forewing (second apical cell broad), most of the species described below resemble these and other genera of endemic South American Erythroneurini described by Dietrich and Dmitriev (2006), including also Amazygina and Napogina, known species of which lack a ventral pygofer appendage. The coloration of these species also resembles that of the various endemic South American genera in that the forewings lack a distinct color pattern and the overall coloration is white or pale yellow with various amounts of dark brown pigmentation (cf. Dietrich and Dmitriev (2006), Figs. 2P-R). Therefore, although they fit the current definition of Zyginama (Dietrich and Dmitriev 2006), the placement of these species in Zyginama is here considered provisional. Recognition of new genera or expansion of the concepts of previously described genera may become warranted as the erythroneurine fauna of South America becomes better known. 


\section{Key to South American Species Provisionally Placed in Zyginama}

1 Aedeagus with conspicuous spicules or serrations posteroventrally (Figs. 62b, 65b) ..................2

1 'Aedeagus with posteroventral surface smooth

2(1) Aedeagus with pair of long slender processes arising well distad of gonopore and curved anteroventrad (Fig. 62b, c)

3(2) Aedeagus with one pair of processes (Fig. 61c)

60. Z. gibba, n. sp.

3' Aedeagus with two pairs of processes (Fig. 62c)

4(3) Pygofer with dorsal appendage very long and slender, extended beyond apex of lobe, without preapical tooth (Fig. 62a); aedeagus with paired preapical processes extended dorsad (Fig. 62b)..... 61. Z. longispina, n. sp 4' Pygofer with dorsal appendage short, not extended to apex of lobe, with preapical ventral tooth (Fig. 63a); aedeagus with paired preapical processes extended ventrad (Fig. 63b)

62. Z. tambopatensis, n. sp.

5(2) Pygofer dorsal appendage furcate (Fig. 64a)

63. Z. furca, n. sp.

5' Pygofer dorsal appendage truncate apically (Fig. 65a) 64. Z. spiculata, n. sp.

6(1) Aedeagal shaft with two pairs of lateral processes (Fig. 67c) or with a single pair of branched processes (Fig. 68c)

6' Aedeagal shaft with one pair of unbranched lateral processes ............................................... 10

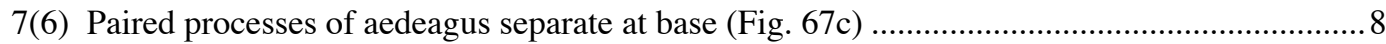

7' Paired processes of aedeagus branched distally (Fig. 68c) ........................................................

8(7) Both pairs of aedeagal processes distinctly preapical, distal pair short and triangular (Fig. 66c) 65. Z. cristata, n. sp.

8 ' Both pairs of aedeagal processes arising at apex, distal pair slender, sinuate (Fig. 67b)

66. Z. elevata, n. sp.

9(7) Aedeagal processes slender with two distal projections (Fig. 68c).... 67. Z. gracilifurca, n. sp. 9' Aedeagal processes lamelliform, with three distal projections (Fig. 69c).

68. Z. intermedia, n. sp.

10(6) Paired aedeagal processes short, triangular (Fig. 70c) 69. Z. adisi, n. sp.

10' Paired aedeagal processes elongate

11(10) Aedeagus in posterior view with apex truncate or emarginate (Figs.71c, 72c) ................. 12

11 ' Aedeagus in posterior view with apex acuminate (Fig. 74c).

12(11) Pygofer dorsal appendage, broad, emarginate apically (Fig. 71a); aedeagus bifid apically (Fig. 71c).... 70. Z. bifida, n. sp. 12' Pygofer dorsal appendage acuminate (Fig. 72a); aedeagus truncate apically (Fig. 72c). 71. Z. truncata, n. sp.

13(11) Aedeagal shaft in lateral view broadest basad of gonopore, apex broader than preapical process (Fig. 73b). 72. Z. ortha, n. sp. 13' Aedeagal shaft in lateral view broadest distad of gonopore, apex narrower than preapical process (Fig. 74b) 73. Z. attenuata, n. sp. 
60. Zyginama gibba, n. sp. (Figs. 4A, 61)

Description. Length of male $3.0-3.2 \mathrm{~mm}$. Ground color dull yellow, infused with brown; crown with large median brown area extended to apex; mesonotum and scutellum mostly brown except medially; mesosternum and abdominal terga brown. Head (Fig. 4A) in dorsal view subequal in width to pronotum, crown longer medialy than next to eye, anterior margin obtusely angulate. Male pygofer (Fig. 61a) with dorsal appendage arising near midlength, slightly elevated above lobe, short, curved mesad, not extended to lobe apex; ventral appendage arising apically, moderately long, bent mesad at $90^{\circ}$ angle; ventrolateral setal group with $\sim 5$ enlarged setae. Aedeagus (Figs. $61 \mathrm{~b}, \mathrm{c}$ ) with preatrium short; dorsal apodeme expanded; spicules absent; shaft compressed, broad in lateral view, apex acuminate, with pair of long slender flattened preapical processes curved ventrolaterad; gonopore posterior near midlength of shaft.

Material examined. Holotype male, ECUADOR, Orellana, $1 \mathrm{~km}$ S Onkonegare Camp, Reserva Etnica Waorani, 00³9'10"S, 076²6'00”'W, 7 October 1995, fogging terra firme forest (T.L. Erwin, et al., lot\#1244) [USNM]; 1 male and 1 female paratype, same data except 26 June 1996, lot\#1598 [INHS, USNM].

Notes. This species resembles species of Hamagina in having a diffuse median dark area on the crown, but is easily distinguished by its distinctive genitalia. The species name refers to the posteriorly gibbous aedeagal shaft.

61. Zyginama longispina, n. sp. (Figs. 4B, 62) Description. Length of male $3.8 \mathrm{~mm}$. Ground color dull yellow; crown with pair of diffuse brown submedial spots preapically; mesonotal triangles dark brown; meskatepisternum dark brown. Head (Fig. 4B) in dorsal view slightly broader than pronotum, crown slightly longer medially than next to eye, anterior margin evenly rounded. Male pygofer (Fig. 62a) with dorsal appendage straight, abruptly narrowed beyond basal third, elongate, extended beyond apex of lobe; ventral appendage arising preapically, elongate, slender, curved slightly mesad then gradually dorsolaterad. Aedeagus (Figs.62b, c) with preatrium short; dorsal apodeme well developed, weakly expanded dorsally; base spiculate ventrally; shaft compressed, broad basally, slender distally, with pair of long slender preapical processes curving anterolaterad and pair of long apical processes curving sinuately ventrad; gonopore near base of shaft on posteroventral surface, bordered by pair of triangular flanges.

Material examined. Holotype male, ECUADOR, Orellana, $1 \mathrm{~km}$ S Onkonegare Camp, Reserva Etnica Waorani, 00³9'10”S, 076²6'00'W, 3 October 1996, fogging terra firme forest (T.L. Erwin, et al., lot\#1738) [USNM].

Notes. This species is similar to Z. adisi in coloration, but is readily distinguished by the distinctive aedeagus and the strongly attenuate dorsal pygofer appendage, upon which the species name is based.

\section{Zyginama tambopatensis, n. sp. (Figs. 4C,} 63)

Description. Length of male $3.0 \mathrm{~mm}$. Ground color pale yellow, crown with diffuse brown area medially, mesonotal triangles and mesepisternum dark brown. Head (Fig. 4C) in dorsal view slightly wider than pronotum, crown slightly longer medially than next to eye, anterior margin evenly rounded. Male pygofer (Fig. 63a) with dorsal appendage arising near midlength, elevated above lobe, short, straight, acute, with ventral preapical projection; ventral appendage arising preapically, long, curved dorsomesad; lobe between appendages rounded; ventrolateral setal group with $\sim 8$ enlarged setae. Aedeagus (Figs. 63b, c) with preatrium short; dorsal apodeme crescent-shaped in lateral view; shaft in lateral view broad basally, nearly straight, with serrate ventrolateral flange, pair of slender ventrally directed processes laterad of gonopore, and pair of long slender apical processes curved anteroventrad; gonopore preapical on posterior surface.

Material examined. Holotype male, PERU, Madre de Dios, Rio Tambopata Res., 30km (air) SW Pto. Maldonado, 290m, 12 ${ }^{\circ} 50 ’ \mathrm{~S}$, $069^{\circ} 17^{\prime} \mathrm{W}$, Smithsonian Institution Canopy Fogging Project, 4 May 1984 01/03/69 (T.L. Erwin, et al.) [USNM].

Notes. This species closely resembles Z. longispina but is readily distinguished by the short, bifid dorsal pygofer appendage and the ventrally directed preapical processes of the aedeagus. The species name refers to the type locality.

63. Zyginama furca, n. sp. (Figs. 4D, 64)

Description. Length of male $2.9 \mathrm{~mm}$. Ground 
color pale yellow; crown unmarked; mesonotal triangles light orange-brown. Head (Fig. 4D) in dorsal view subequal in width to pronotum, crown longer medially than next to eye, anterior margin obtusely angulate. Male pygofer (Fig. 64a) with dorsal appendage greatly enlarged, arising in basal half, elevated and strongly divergent from margin of lobe; branched near midlength, branches acuminate, both extended slightly beyond apex of lobe; ventral appendage arising preapically, moderately long, curved dorsomesad; lobe between appendages with prominent hump; ventrolateral setal group with $\sim 6$ enlarged setae. Aedeagus (Figs. 64b, c) with preatrium short; dorsal apodeme in lateral view broadly rounded; shaft very broad and strongly compressed, with pair of lamelliform lateral flanges; posterior margin irregularly serrate; processes absent; gonopore apical.

Material examined. Holotype male, PERU, Madre de Dios, Rio Tambopata Res., 30km (air) SW Pto. Maldonado, 290m, 12 ${ }^{\circ} 50$ 'S, 069 $17^{\prime} \mathrm{W}$, Smithsonian Institution Canopy Fogging Project, 8 November 1983 04/01/147 (T.L. Erwin, et al.) [USNM].

Notes. This species is similar externally to $Z$. cristata, but is readily distinguished by its massive forked dorsal pygofer appendage and short, broad, posteriorly serrate aedeagus. The species name refers to the forked pygofer appendage.

\section{Zyginama spiculata, n. sp. (Figs. 4E, 65)}

Description. Length of male $3.2 \mathrm{~mm}$. Ground color pale yellow, unmarked. Head (Fig. 4E) in dorsal view subequal in width to pronotum, crown slightly longer medially than next to eye, anterior margin evenly rounded. Male pygofer (Fig. 65a) with dorsal appendage arising in basal half, elevated and arcuate above lobe, slender, slightly expanded distally, extended slightly beyond lobe, apex truncate and indistinctly crenulate; ventral appendage arising preapically, short, curved dorsad; ventrolateral setal group with $\sim 6$ slightly enlarged setae. Aedeagus (Figs. 65b, c) with preatrium well developed; dorsal apodeme in lateral view parallel sided; shaft short, with compressed dorsal lobe and pair of large denticulate ventrolateral flanges; gonopore preapical on posterior surface.

Material examined. Holotype male, PERU, Madre de Dios, Rio Tambopata Res., 30km (air) SW Pto. Maldonado, 290m, 1250'S, $069^{\circ} 17^{\prime} \mathrm{W}$, Smithsonian Institution Canopy Fogging Project, 8 November 1983 04/01/147 (T.L. Erwin, et al.) [USNM].

Notes. This species is similar to Z. furca, but is most easily distinguished by the form of the pygofer dorsal appendage, which is not forked but truncate and weakly crenulate distally. The species name refers to the spiculate aedeagus.

\section{Zyginama cristata, n. sp. (Figs. 4F, 66)}

Description. Length of male 3.1-3.2 mm, female $3.1 \mathrm{~mm}$. Ground color pale yellow; crown unmarked; mesonotal triangles dark brown. Head (Fig. 4F) in dorsal view subequal in width to pronotum, crown longer medially than next to eye, anterior margin evenly rounded. Male pygofer (Fig. 66a) with dorsal appendage arising near base, elevated above margin of lobe, long, acuminate, curved ventrad, extended nearly to apex of lobe; ventral appendage arising preapically, long, curved dorsomesad; lobe between appendages rounded; ventrolateral setal group with $\sim 4$ enlarged setae. Aedeagus (Figs. 66b, c) without preatrium; dorsal apodeme in lateral view slightly broadened dorsally; shaft slender, slightly recurved, without basal processes; with two pairs of distal processes arising preapically, one pair arising just basad of gonopore, slender, elongate, extended ventrolaterad then curved anterodorsad; other pair arising laterad of gonopore, short, triangular; apical lobe compressed, bluntly rounded in lateral view; gonopore preapical on posterior surface.

Material examined. Holotype male, ECUADOR, Orellana, 1km S Onkonegare Camp, Reserva Etnica Waorani, 00³9'10”S, 076²6'00'W, 10 February 1999, fogging terra firme forest (T.L. Erwin, et al., lot\#976) [USNM]; 2 female paratypes, same data; 1 male paratype, same data except 30 September 1996, lot\#1665 [INHS]; 1 male paratype, same data except 4 October 1995, lot \#1176 [USNM].

Notes. This species is somewhat similar to Z. attenuata externally, but is readily distinguished by its distinctive aedeagus. The species name refers to the crested aedeagal apex.

66. Zyginama elevata, n. sp. (Figs. 4G, 67) Description. Length of male $3.2 \mathrm{~mm}$. Ground color dull yellow, heavily marked with brown; face except frontoclypeus medially, gena, and 
lora brown; crown brown except pair of pale oblique marginal areas and pair of obscure black preapical spots brown; pronotum brown; mesonotum and scutellum mostly brown; forewing brown; mesosternum and abdominal terga dark brown. Head (Fig. 4G) in dorsal view broader than pronotum, crown no longer medially than next to eye, anterior margin broadly rounded. Male pygofer (Fig. 67a) with dorsal appendage arising near midlength, elevated and strongly divergent from margin of lobe, short, acuminate, curved posteroventrad, not extended to apex of lobe; ventral appendage arising preapically, long, curved dorsomesad; lobe between appendages with prominent hump; ventrolateral setal group with $\sim 5$ enlarged setae. Aedeagus (Figs. 67b, c) with preatrium short; dorsal apodeme in lateral view slender, slightly broadened dorsally; shaft in lateral view elongate, slender, slightly sinuate, with short retrorse spine near midlength of dorsal margin; basal processes absent; with two pairs of short, slender distal processes, one arising preapically, extended ventrad and curved slightly anterad; the other arising at apex, arched laterad and curved posteroventrad; apical lobe absent; gonopore apical.

Material examined. Holotype male, ECUADOR, Orellana, $1 \mathrm{~km}$ S Onkonegare Camp, Reserva Etnica Waorani, 00³9'10'S, 076²6'00'W, 2 July 1995, fogging terra firme forest (T.L. Erwin, et al., lot\#1067) [USNM]. Notes. The mostly dark brown coloration of this species is unique among known South American Erythroneurini, and the male genitalia are also distinctive. The species name refers to the elevated distal pair of aedeagal processes.

67. Zyginama gracilifurca, n. sp. (Figs. 4H, 68) Description. Length of male $3.1 \mathrm{~mm}$. Ground color dull yellow, infused with brown; crown with pair of diffuse brown submedial spots preapically; mesonotum and scutellum dark brown; mesosternum and abdominal terga dark brown. Head (Fig. 4H) in dorsal view subequal to pronotum in width, crown slightly longer medially than next to eye, anterior margin evenly rounded. Male pygofer (Fig. 68a) with dorsal appendage arising near midlength, not elevated above margin of lobe, acuminate, straight, extended nearly to apex of lobe; ventral appendage long, curved dorsomesad; lobe between appendages parabolically rounded; ventrolateral setal group conspicuous but setae not enlarged. Aedeagus (Figs. 69b, c) without preatrium; dorsal apodeme in lateral view nearly parallel-sided; shaft in lateral view very slender, elongate, slightly recurved, without basal processes; with pair of distal processes arising well basad of gonopore, extended ventrad then curved anterolaterad, shallowly forked apically; distal lobe compressed, acuminate in lateral view; gonopore preapical on posterior surface.

Material examined. Holotype male, ECUADOR, Orellana, $1 \mathrm{~km}$ S Onkonegare Camp, Reserva Etnica Waorani, 00³9'10"S, 076²6'00'W, 30 September 1996, fogging terra firme forest (T.L. Erwin, et al., lot\#1667) [USNM].

Notes. This species is similar to Z. adisi externally, but is easily identified by the aedeagus, the very slender shaft and forked preapical processes of which are distinctive and upon which the species name is based.

\section{Zyginama intermedia, n. sp. (Figs. 4I, 69)}

Description. Length of male $3.1 \mathrm{~mm}$. Ground color pale yellow, crown and pronotum heavily infused with brown, mesonotal triangles and mesepisternum dark brown. Head (Fig. 3I) in dorsal view subequal to pronotum in width, slightly longer medially than next to eye, anterior margin evenly rounded. Male pygofer (Fig. 8Y) with dorsal appendage arising near midlength, elevated above and divergent from dorsal margin of lobe, slender, nearly straight, extended nearly to apex of lobe, with 1-2 enlarged setae at base; ventral appendage arising at apex, short, extended posterodorsad; lobe between appendages nearly straight; ventrolateral setal group with $\sim 6$ enlarged setae. Aedeagus (Figs. 8Z, AA) without preatrium; dorsal apodeme in lateral view strongly expanded dorsally; shaft compressed, in lateral view moderately broad, slightly recurved, without basal processes; paired distal processes arising adjacent to gonopore, lamelliform, with two short ventral preapical projections and elongate distal spine curved anterodorsad; distal lobe compressed, bluntly rounded in lateral view; gonopore preapical on posterior surface.

Material examined. Holotype male, PERU, Madre de Dios, Rio Tambopata Res., 30km (air) SW Pto. Maldonado, 290m, 12 ${ }^{\circ} 50$ 'S, $069^{\circ} 17^{\prime} \mathrm{W}$, Smithsonian Institution Canopy Fogging Project, 14 September 1984 01/02/61 (T.L. Erwin, et al.) [USNM]. 
Notes. This species resembles $Z$. gibba in coloration. The presence of enlarged setae near the base of the dorsal pygofer appendage is a trait shared with species of the New World genus Neozygina. Nevertheless, other aspects of the morphology of this species, including the presence of enlarged setae in the ventrolateral setal group and the absence of distinct preapical spots on the crown indicate that the species is not closely related to Neozygina. The species name refers to the apparently intermediate position of this species between Neozygina and Zyginama.

69. Zyginama adisi, n. sp. (Figs. 4J, 70) Description. Length of male $2.8 \mathrm{~mm}$, female $2.9 \mathrm{~mm}$. Ground color pale yellow; crown with pair of small brown submedial spots preapically; mesonotal triangles dark brown. Head (Fig. $4 \mathrm{~J}$ ) in dorsal view subequal to pronotum in width, crown longer medially than next to eye, anterior margin forming obtuse angle. Male pygofer (Fig. 70a) with dorsal appendage long, broadened, compressed, and slightly twisted preapically, apex attenuate, not extended to apical margin; ventral process arising near apex, slender, extended mesad; lobe between appendages subangulate; ventrolateral setal group with 5-8 conspicuous setae. Aedeagus (Figs. 70b, c) with preatrium well developed; dorsal apodeme strongly expanded in lateral view, pillarlike in posterior view; shaft tubular, slightly compressed, slender, with pair of short broad triangular processes preapically; gonopore apical.

Material examined. Holotype male, BRASIL, Amazonas, Hwy ZF 2, km 20.7, ca 60 km N Manaus, $02^{\circ} 30^{\prime} \mathrm{S} 060^{\circ} 15^{\prime} \mathrm{W}, 16$ Aug 1979 , terra firme; Canopy Fogging Project TRS\#08, Tray \#547, Adis, Erwin, Montgomery, et al.; 3 male, and 1 female paratypes, same data [USNM]. Notes. This species is very similar externally to several other South American Erythroneurini and is most readily identified by its distinctive male genitalia, e.g., the preapically expanded dorsal pygofer appendage and the slender aedeagal shaft with very short processes. The species is named in honor of the collector of the type series, Prof. Joachim Adis, who has made substantial contributions to knowledge of the Neotropical insect fauna.

70. Zyginama bifida, n. sp. (Figs. 4K, 71)

Description. Length of male $3.3 \mathrm{~mm}$, female $3.3 \mathrm{~mm}$. Ground color pale yellow; crown with pair of light brown preapical spots, apex with short median brown longitudinal stripe; mesepisternum, mesonotal triangles, and abdominal terga brown. Head (Fig. 4K) in dorsal view slightly wider than pronotum, crown longer medially than next to eye, anterior margin forming obtuse angle. Male pygofer (Fig. 71a) with dorsal appendage arising near base, elevated above dorsal margin of lobe, short, broad, apex bifid, with acute dorsal projection and rounded ventral lobe, not extended to apex of lobe; ventral appendage arising preapically, greatly elongate, twisted, curved dorsomesad; lobe between appendages rounded; ventrolateral setal group vestigial. Aedeagus (Figs. 71b, c) with preatrium short; shaft compressed, in lateral view broad; subbasal processes absent; distal processes arising distad of gonopore, long, slender, curved ventrolaterad; apex bifid; gonopore arising near midlength of shaft. Material examined. Holotype male, PERU, Madre de Dios, Rio Tambopata Res., $30 \mathrm{~km}$ (air) SW Pto. Maldonado, 290m, 12 ${ }^{\circ} 50$ 's, $069^{\circ} 17^{\prime} \mathrm{W}$, Smithsonian Institution Canopy Fogging Project, 10 November 1983, 03/02 (T.L. Erwin, et al.) [USNM]; 1 male paratype, same data [INHS]; 1 male paratype same data except 4 May 1984, 01/02/86 [USNM].

Notes. This species resembles $Z$. adisi in coloration but differs in having the crown shorter. It is unusual in lacking the ventrolateral setal group on the male pygofer. The species name refers to the bifid apex of the aedeagus.

71. Zyginama truncata, n. sp. (Figs. 4L, 72) Description. Length of male $3.2 \mathrm{~mm}$. Ground color pale yellow; crown unmarked; mesonotal triangles light brown; mesepisternum and abdominal terga light brown. Head (Fig. 4L) in dorsal view subequal in width to pronotum, crown longer medially than next to eye, anterior margin obtusely angulate. Male pygofer (Fig. 72a) with dorsal appendage arising near midlength, elevated above lobe, acuminate, nearly straight, ventral areolate, not extended to lobe apex; ventral appendage arising preapically, moderately long, extended dorsomesad; ventrolateral setal group with $\sim 3$ enlarged setae. Aedeagus (Fig. 72b, c) without preatrium; dorsal apodeme in lateral view slender; shaft compressed, in lateral view straight through most of length with basally angulate dorsal keel arising near midlength and extended to apex; subbasal processes absent; paired distal processes long, 
slender, curved anterad; apex blunt, with pair of short triangular projections in posterior view; gonopore preapical on posterior surface.

Material examined. Holotype male, ECUADOR, Orellana, $1 \mathrm{~km}$ S Onkonegare Camp, Reserva Etnica Waorani, 00³9'10"S, 076²6'00'W, 30 September 1996, fogging terra firme forest (T.L. Erwin, et al., lot\#1696) [USNM].

Notes. This species closely resembles Z. attenuata but is easily distinguished by the distinctively broadened aedeagal apex. The species name refers to the truncate aedeagal apex.

\section{Zyginama ortha, n. sp. (Figs. 4M, 73)}

Description. Length of male $3.1 \mathrm{~mm}$, female $3.1 \mathrm{~mm}$. Ground color dull yellow; crown with very indistinct pair of brown submedial spots preapically; mesonotal triangles dark brown; meskatepisternum and abdominal terga brown. Head (Fig. 4M) in dorsal view subequal in length to pronotum, crown slightly longer medially than next to eye, anterior margin evenly rounded. Male pygofer (Fig. 73a) with dorsal appendage arising in basal half, elevated above and divergent from dorsal margin of lobe, nearly straight, acuminate, extended nearly to apex of lobe; ventral appendage arising at apex, long, extended posterodorsad; lobe between appendages rounded; ventrolateral setal group with $\sim 4$ enlarged setae. Aedeagus (Figs. 73b, c) without preatrium; dorsal apodeme in lateral view slightly broadened dorsally; shaft compressed, in lateral view moderately broad, nearly straight, without basal processes; paired distal processes arising adjacent to gonopore, slender, extended ventrad then curved anterodorsad; distal lobe compressed, bluntly rounded in lateral view.

Material examined. Holotype male, ECUADOR, Orellana, $1 \mathrm{~km}$ S Onkonegare Camp, Reserva Etnica Waorani, 00 39'10'S, 076²6’00"W, 13 February 1999, fogging terra firme forest (T.L. Erwin, et al., lot\#1032) [USNM]; 2 female paratypes, same data. Notes. This species resembles $Z$. attenuata but differs in having paired spots on the crown, the dorsal pygofer appendage shorter, and the aedeagal shaft in lateral view broadest basad of the gonopore.

73. Zyginama attenuata, n. sp. (Figs. 4N, 74)

Description. Length of male $3.0 \mathrm{~mm}$, female $3.2 \mathrm{~mm}$. Ground color pale yellow, unmarked except indistinct tan mark at crown apex and dark brown mesonotal triangles. Head (Fig. $4 \mathrm{~N}$ ) in dorsal view subequal to pronotum in width, crown longer medially than next to eye, anterior margin forming obtuse angle. Male pygofer (Fig. 74a) with dorsal appendage arising in basal half, elevated above margin of lobe, attenuate, straight, extended nearly to apex of lobe; ventral appendage arising preapically, long, curved dorsomesad; lobe between appendages rounded; ventrolateral setal group with $\sim 1$ enlarged seta. Aedeagus (Figs. 74b, c) without preatrium, dorsal apodeme in lateral view weakly expanded dorsally; shaft strongly compressed, in lateral view nearly straight, gradually broadened toward apex; basal processes absent; distal paired processes arising distad of gonopore, long, slender, extended laterad and curved anterodorsad; apical lobe attenuate; gonopore preapical on posterior surface.

Material examined. Holotype male, PERU, Madre de Dios, Rio Tambopata Res., 30km (air) SW Pto. Maldonado, 290m, 12 ${ }^{\circ} 50$ 'S, $069^{\circ} 17^{\prime} \mathrm{W}$, Smithsonian Institution Canopy Fogging Project, 8 November 1983 04/01/03 (T.L. Erwin, et al.) [USNM].

Notes. This species resembles several other South American Erythroneurini externally but is easily recognizable by the distinctive form of the aedeagus. The species name refers to the attenuate tip of the aedeagus. 


\section{References}

Beamer, R.H. 1927a. New species of Erythroneura (Homoptera: Cicadellidae). Canadian Entomologist 59:30-31.

Beamer, R.H. 1929b. Erythroneura (Homoptera, Cicadellidae) from the Southwest. Annals of the Entomological Society of America 22(1): 115-129.

Beamer, R.H. 1932i. Some Erythroneura from the Western United States (Homoptera, Cicadellidae). Journal of the Kansas Entomological Society 5(4): 123-127.

Beamer, R.H. 1934a. A new genus and two new species of leafhoppers from California (Homoptera Cicadellidae). Pan-Pacific Entomologist 10(1): 43-44.

Beamer, R.H. 1934c. Notes on some western Erythroneura with description of three new species (Homoptera: Cicadellidae). Journal of the New York Entomological Society 42: 285-288.

Beamer, R.H. 1937b. Three new western species of Erythroneura (Homoptera - Cicadellidae). Annals of the Entomological Society of America 30(1): 31-33.

Dietrich, C.H., and D.A. Dmitriev. 2006.

Review of the New World genera of the leafhopper tribe Erythroneurini (Hemiptera: Cicadellidae: Typhlocybinae). Illinois Natural History Survey Bulletin 37: i-iv, 119-190.

Dietrich, C.H., and D.A. Dmitriev. 2007. Revision of the New World leafhopper genus Neozygina Dietrich \& Dmitriev (Hemiptera: Cicadellidae: Typhlocybinae: Erythroneurini). Zootaxa 1475: $27-42$.

Dmitriev, D.A., and C.H. Dietrich. 2007. Review of the New World Erythroneurini (Hemiptera: Cicadellidae: Typhlocybinae). I. Genera Erythroneura, Erasmoneura, Rossmoneura, and Hymetta. Illinois Natural History Survey Bulletin 38(2):59-128.

Gillette, C.P. 1898a. American leaf-hoppers of the subfamily Typhlocybinae. Proceedings of the United States National Museum 20(1138):709-773.
Kirkaldy, G.W. 1907d. Leafhoppers supplement (Hemiptera). Bulletin of the Experiment Station of the Hawaiian Sugar Planters' Association. (Entomological series) 3:1-186, pl. 1-20.

Knull, D.J. and M. Auten. 1938a. Some Erythroneura from the Southwest (Homoptera: Cicadellidae). Annals of the Entomological Society of America 31:532-539.

McAtee, W.L. 1920a. Key to the nearctic species and varieties of Erythroneura (Homoptera; Eupterygidae). Transactions of the American Entomological Society 46:267-321, pl. XII.

McAtee, W.L. 1924c. Notes on eupterygid leafhoppers with descriptions of a few forms (Homoptera). Florida Entomologist 8(3-4):33-39.

McAtee, W.L. 1924d. Records of species of the genus Erythroneura (Homoptera; Eupterygidae) with descriptions of new forms. Proceedings of the Biological Society of Washington 37: 131-134.

Ross, H.H. 1965a. The phylogeny of the leafhopper genus Erythroneura (Hemiptera, Cicadellidae). Zoologische Beiträge 11(1-2):247-270.

Swofford, D.L.1998. PAUP*: Phylogenetic Analysis Using Parsimony (*and other methods), version 4. Sinauer, Sunderland, Massachusetts.

Van Duzee, E.P. 1924a. The genus Erythroneu$r a$ in California (Homoptera). Proceedings of the California Academy of Sciences (4). 13(13):231-236.

Young, D. A. 1952. A reclassification of Western Hemisphere Typhlocybinae (Homoptera, Cicadellidae). University of Kansas Science Bulletin 35:1-217. 
Appendix A. Morphological characters. Characters 1, 11, 12, 14, 15, 20, 23, 25, 26, 30, and 32 were treated as ordered (additive) in the phylogenetic analysis; others were treated as unordered.

1. Head in dorsal view with anterior margin: 0 , broadly rounded; 1 , obtusely angulate; 2 , forming ca. $90^{\circ}$ angle; 3 , acutely produced.

2. Pygofer lobe dorsal margin: 0 , convex; 1 , concave

3. Pygofer dorsal appendage, origin: 0 , in basal half of lobe; 1 , in distal half of lobe.

4. Pygofer dorsal appendage, length: $0,>$ half length of lobe; $1,<$ half length of lobe.

5. Pygofer dorsal appendage, serrations: 0 , absent; 1 , present.

6. Pygofer dorsal appendage, shape: 0 , slender, acuminate; 1 , slender, blunt apically; 2 , broad with acute apex; 3 , truncate apically; 4, bifid; 5, with long, slender preapical spine; 6 , with dorsal preapical angle.

7. Pygofer dorsal appendage, elevation: 0 , not elevated above dorsal margin of lobe; 1 , elevated above dorsal margin of lobe throughout length.

8. Pygofer dorsal appendage, curvature: 0, curved upward; 1, straight; 2, curved downward; 3 , distinctly sinuate.

9. Pygofer ventral appendage: 0 , absent, ventral margin of lobe weakly sclerotized; 1 , present; 2, vestigial, ventral margin of lobe strongly sclerotized.

10. Pygofer ventral appendage, origin: 0 , ventral, preapical; 1 , at or near apex of lobe.

11. Pygofer ventral appendage, length: $0,>$ half length of lobe; $1,<$ half length of lobe; 2 , very short, toothlike.

12. Ventrolateral setae: 0 , absent; $1,1-2$ present; $2,3-5$ present; 3,6 or more present.

13. Aedeagus ventrolateral flange: 0 , absent; 1 , present.

14. Aedeagal shaft width in lateral view: 0 , very slender, no broader in lateral view than in posterior view; 1, broader in lateral view than in posterior view; 2 , less than twice as long as broad; 3 , as broad as long.

15. Aedeagal shaft shape in lateral view: 0 , evenly recurved; 1 , straight through most of length, posterior margin not concave preapically; 2 , sinuate with posterior margin concave preapically.

16. Aedeagus apex in lateral view: 0 , acuminate; 1 , rounded; 2 , broadly angulate; 3 , falcate.

17. Aedeagus shaft apex: 0 , not strongly recurved ventrad; 1 , strongly recurved ventrad.

18. Aedeagus apex, posterior view: 0 , slender, acuminate; 1 , broad, rounded; 2 , weakly emarginate; 3 , deeply cleft.

19. Aedeagus dorsal retrorse preapical spine: 0 , absent; 1 , present.

20. Aedeagus paired basal processes, position relative to shaft: 0 , posterad; 1 , laterad through most of length.

21. Aedeagus posterior preapical spine: 0 , absent; 1 , present.

22. Aedeagus basal process(es): 0, absent; 1, present, paired; 2, present, unpaired.

23. Aedeagus paired distal processes: 0 , absent; 1 , present, even with or basad of gonopore; 2, present distad of gonopore.

24. Aedeagus paired distal processes, length: 0 , short, triangular; 1 , short, slender; 2 , long, slender.

25. Aedeagus paired distal processes, orientation in lateral view: 0, extended anterad; 1 , extended laterad; 2 , extended posterad.

26. Aedeagus paired distal processes, orientation in posterior view: 0 , ventrad; 1 , ventrolaterad; 2, laterad; 3, dorsad.

27. Aedeagus paired distal processes: 0 , unbranched; 1 , branched.

28. Aedeagus paired teeth or keels near midlength of shaft: 0 , absent; 1 , present.

29. Aedeagus anterior hump near midlength of shaft: 0 , absent; 1 , present.

30. Aedeagus preatrium: 0 , very short; 1 , well developed but distinctly shorter than shaft; 2 , subequal to or longer than shaft.

31. Aedeagus dorsal apodeme: 0 , slender; 1 , broad.

32. Gonopore: 0 , apical; 1 , preapical on posterior surface; 2, at or basad of midlength.

33. Head: 0, without small black apical spot; 1, with small black apical spot. 
34. Face: 0, without transverse brown band dorsallly; 1, with transverse brown dorsal band.

35. Face (color): 0, more or less uniformly pale or brown; 1, with distinct transition between dark ventral section and pale dorsal margin.

36. Crown (paired dark spots): 0, without pair of dark brown preapical spots; 1 , with pair of dark brown preapical spots.

37. Crown (oranage maculae): 0 , without orange maculae; 1 , with pair of orange maculae; 2 , with median orange macula.

38. Scutellum apex: 0 , not black; 1 , black, contrasting with pale anterior region.

39. Forewing color pattern: 0, markings indistinct or absent; 1 , with oblique longitudinal yellow or orange stripes; 2 , with symmetrically arranged brown or reddish patches; 3 , with transverse bands.

40. Pronotum: 0 , with pair of triangular orange spots; 1 , with pair of curved orange submedial stripes; 2, with median V- or U-shaped mark; 3, anterior two-thirds red with white anterolateral spots; 4 , with median posterior orange area, anterolateral border white; 5 , without distinct markings. 
Appendix B. Data matrix for phylogenetic analysis. Character codes correspond to descriptions in Appendix A. Question marks indicate that the character is missing or inapplicable for the corresponding taxon.

1111111111222222222233333333334

Taxon/Character 1234567890123456789012345678901234567890

Z. agnata

Z. arizonica

Z. aucta

Z. blanda

Z. casta

Z. cimmaroni

Z. cornigera

$Z$. erosa

Z. grandis

Z. iguala

Z. inornata

Z. merita

Z. munda

Z. nicholi

z. novella

Z. nuda

Z. obscura

Z. pallenta

Z. pinalensis

Z. ritana

Z. rubicunda

Z. sola

Z. spectabilis

Z. triceroprocta

$z$. tricolor

Z. tripunctata

z. unicolor

z. utahna

Z. angulata

Z. brunnedorsum

Z. carapana

Z. coahuilensis

z. colima

Z. colorada

z. cuernavaca

Z. durangensis

Z. elongata

$Z$. enigmata

Z. Ianceolata

Z. maculipennis
2000010211220101000101120200000100000501 2000010211130112000111221001011100000101 2011021210130011020?020????0000100001001 $2000020210130101010 ? 00220110010100000 ? 01$ 2000000111120101000001221000000110001101 $2000000011120110000 ? 00220200011100001 ? 01$ 200000022 ??20001010101220110000100001001 2000000211120001000001120110000100001012 11010002101301000001010 ????0000100101302 $2000020210130101000011122000000100002 ? 03$ $2011060210110220000 ? 10120300111100010 ? 00$ 2011021211130011020 ?020????0101100001001 $201102011002010 ? 0001010$ ????0011100002400 2101000210120110000001100200000100101303 $2011010311110112000 ? 02200200001100001101$ $2000010311010101000 ? 0022 ? ? 00011200000 ? 00$ 2000000311120011000001100100000100000500 $2010000110020100000 ? 00100200010100001 ? 01$ $2011020210120220000 ? 10110200111100001101$ 20100002101302010101010 ????0010100000401 1101000210120110000001100200000100001302 $2000050210130001000001110200000100001 ? 02$ 21010601101301100000010 ????0000100101303 $1001000111230000000 ? 00120310000100001 ? 01$ 3001000110020021000 ?100????0000101000402 20000002111200010000010 ????0000110010?11 $2000040210120001000001120 ? 00010100000500$ $20 ? 1060211110100000 ? 10120100001100001 ? 01$ $200102021122000 ? 0 ? 0001120210000100101111$ $3010000311120220000 ? 10120100111100000 ? 02$ 20100202101200010001010 ????0011100000411 $200000011112010100010121 ? ? 00000110010111$ 2010050210230001000 ?000????1000110000012 $1010000311110110000 ? 10122100011100001 ? 01$ 20000201101300010000010 ????0000110000012 2000000210120111000001120201000100001101 $2001020111120111000001221000000110000 ? 11$ 2010010310110221000001110100111100001 ? 11 2111000011120010001 ?100????0000100000502 20010202101000200000010 ????0011100000110 
Appendix B continued.

1111111111222222222233333333334

Taxon/Character 1234567890123456789012345678901234567890

Z. malleta

?0000102101201120001010????10001??????11

Z. multifurca $2001040110130000030 ? 00220110000110010 ? 1$ ?

Z. ochrescens $2011011211120001010 ? 00121000000100000502$

Z. olmeca

Z. orizaba

Z. pallescens $2100001211220102000 ? 00120100000101002202$ $2000000211120000000101100200000110000 ? 10$ $200102021011011 ? 030 ? 00121100001100001$ ? 12

$Z$. panamensis 1001000210120011001 ?100????0001100000?12

Z. queretarensis

$z$. rodmani $2001010210120111000101121001000110010 ? 12$ 20000001112201110000010 ????0000110011?12

$z$. rossi

Z. rubrocta

Z. serrata

Z. spatulata

Z. tolteca

Z. toluca

Z. vittata

Z. zitacuarensis

$z$. adisi

Z. attenuata

Z. bifida

Z. cristata

Z. elevata

Z. furca

Z. gibba

Z. gracilifurca 2101000110130110000001121000000100111302 $2000000210030012000 ? 02120000000100002 ? 03$ $1000131010101211000 ? 00120200010210000 ? 00$ $2000010310110112000 ? 00110200011100001 ? 01$ 2000001110000001000 ?000????0010100101212 $2000001111130111030 ? 00220210100110010 ? 11$ $2001000211110011030 ? 00120 ? 10011100001 ? 01$ 20000002111201120001010 ????1000100001111 $1000020110130001000 ? 0010 ? 200010000010500$ $1000001110110110000 ? 00220100000110000500$ $1001041110000101030 ? 00221100001100010500$ $1000001210120001000 ? 00120100000100000500$ $001100121002001 ? 031 ? 00121 ? 10000000000500$ 100004111013131 ?0?0?000????0001?00000500 $2011021011130001000 ? 00220100000200000500$ $1010000010020000000 ? 00120110000110010500$ $2011001211130101000 ? 00120110000110000500$ $000000111003101 ? 100 ? 00220 ? 00000200010500$ $1000001111020111000 ? 00120100000110010500$ 10001312101313120 ?0?000????0000?00000500 $101104121003111 ? 100 ? 00222$ ??0000200010500 $1000001210120111030 ? 00121100000100000500$ 20??????00020201030?001?1200000100020?0? 


\section{Species Index}

(junior synonyms in italics; pages of individual species accounts in bold)

adisi n. sp.

$153,154,156,157,163,169,175$

agnata Knull \& Auten

$135,144,145,162,168 ., 172$

ales Beamer

137,167

angulata n. sp.

$134, \mathbf{1 4 4}, 162,167,172$

arizonica Knull \& Auten

$134,142,162,167,171$

attenuata $\mathrm{n}$. $\mathrm{sp}$.

$153,155,158,163,169,175$

aucta McAtee.

$132,137,143,162,167,170$

bifida n. sp.

$153,157,163,169,175$

bilocularis Van Duzee

blanda Knull \& Auten

$136,151,162,168,174$

brunnedorsum n. sp.

$135,143,147,162,168,173$

canyonensis Beamer

137,167

carapana n. sp.

casta Beamer.

$133,139,162,167,170$

cimmaroni Beamer.

$135,145,162,168,172$

coahuilensis n. sp.

$136,149,162,168,173$

colima n. sp.

$133,140,143,162,167,171$

colorada n. sp.

$135,139,140,146,162,168,172$

cornigera Beamer

$136,143,148,162,168,173$

cristata n. sp.

$131,134,145,162,168,172$

cuernavaca n. sp.

$153,155,163,169,175$

dentata Gillette.

$133,139,162,167,170$

durangensis $\mathrm{n}$. $\mathrm{sp}$. $132,137,167$

elevata n. sp.

$134,144,162,168,172$

elongata $\mathrm{n}$. $\mathrm{sp}$.

$153, \mathbf{1 5 5}, 163,169,175$

enigmata $\mathrm{n}$. $\mathrm{sp}$

$134,142,162,167,171$

erosa McAtee.

$134,143,162,167,171$

furca n. sp.

$134,145,146,162,168,172$

gibba n. sp.

$153,154,155,163,169,175$

gracilifurca $n$. sp.

$153,154,157,163,169,175$

grandis Beamer.

iguala Ross

$153,156,163,169,175$

inclita Beamer

$132,137,138,162,167,170$

$133,142,162,167,171$

inornata McAtee

intermedia n. sp.

$136,143,149,162,168,173$

juglandacae Ross \& Delong.

$131,152,153, \mathbf{1 5 6}, 163,169,175$

lanceolata $\mathrm{n}$. $\mathrm{sp}$.

longispina $\mathrm{n} . \mathrm{sp}$

$135, \mathbf{1 4 6}, 162,168.172$

maculipennis $\mathrm{n}$. $\mathrm{sp}$

$153,154,163,169,175$

malleta $\mathrm{n}$. sp.

$133,139,162,167,170$

$133,141,163,167,171$

merita Beamer

$132,137,162,167,170$

modula Knull \& Auten

multifurca n. sp.

munda Knull \& Auten.

$136,148,163,168,173$

nicholi Beamer.

$132,138,140,162,167,170$

novella Knull \& Auten

$131,133, \mathbf{1 3 7}, 138,162,167,170$

nuda Knull \& Auten

$133,142,162,167,171$

obscura Beamer

$135,147,162,168,173$

ochrescens n. sp.

$134,144,162,167,172$

olmeca n. sp.

$131,136, \mathbf{1 5 0}, 163,168,174$

$136,147,151,163,168,174$ 
orizaba $\mathrm{n} . \mathrm{sp}$

$133, \mathbf{1 4 0}, 163,167,171$

ortha n. sp.

$153,158,163,169,175$

pallenta Beamer

$136,151,162,168,174$

pallescens $\mathrm{n}$. $\mathrm{sp}$.

$136,151,163,168,174$

panamensis $\mathrm{n}$. $\mathrm{sp}$

$135,145,163,168,172$

pinalensis Beamer

$135,143,147,148,162,168,173$

queretarensis $\mathrm{n}$. $\mathrm{sp}$

$134,143,163,167,171$

ritana Beamer.

$130,131,132, \mathbf{1 3 8}, 146,162,167,170$

rodmani n. sp.

rossi n. sp.

$134,138,163,167,170$

rubicunda Beamer

$134,137,138,162,167$

rubrocta $\mathrm{n}$. sp. $133,142,163,167,171$

serrata n. sp.

$131,136,149,163,168,174$

sola Knull \& Auten

$134,145,162,168,172$

spatulata n. sp.

$136,149,163,168,174$

spectabilis Knull \& Auten.

$132,137,162,167,170$

spiculata n. sp.

$153, \mathbf{1 5 5}, 163,169,175$

tambopatensis n. sp.

$153,154,163,169,175$

ternaria Van Duzee. 132, 152, 168

tolteca n. sp.

$135,146,163,168,173$

toluca n. sp.

$136,150,163,168,174$

triceroprocta Beamer

$135,144,148,, 162,168,173$

tricolor Beamer $135,146,162,168,173$

tripunctata Beamer.

$148,151,162,167,170$

truncata $\mathrm{n}$. $\mathrm{sp}$.

$153,157,163,169,175$

unicolor Beamer.

$134,144,145,162,168,172$

utahna Beamer

$136,148,149,162,168,173$

vittata $\mathrm{n}$. $\mathrm{sp}$.

$136,142,148,163,168,173$

zitacuarensis n. sp.

$133,141,163,167,171 ß$ 


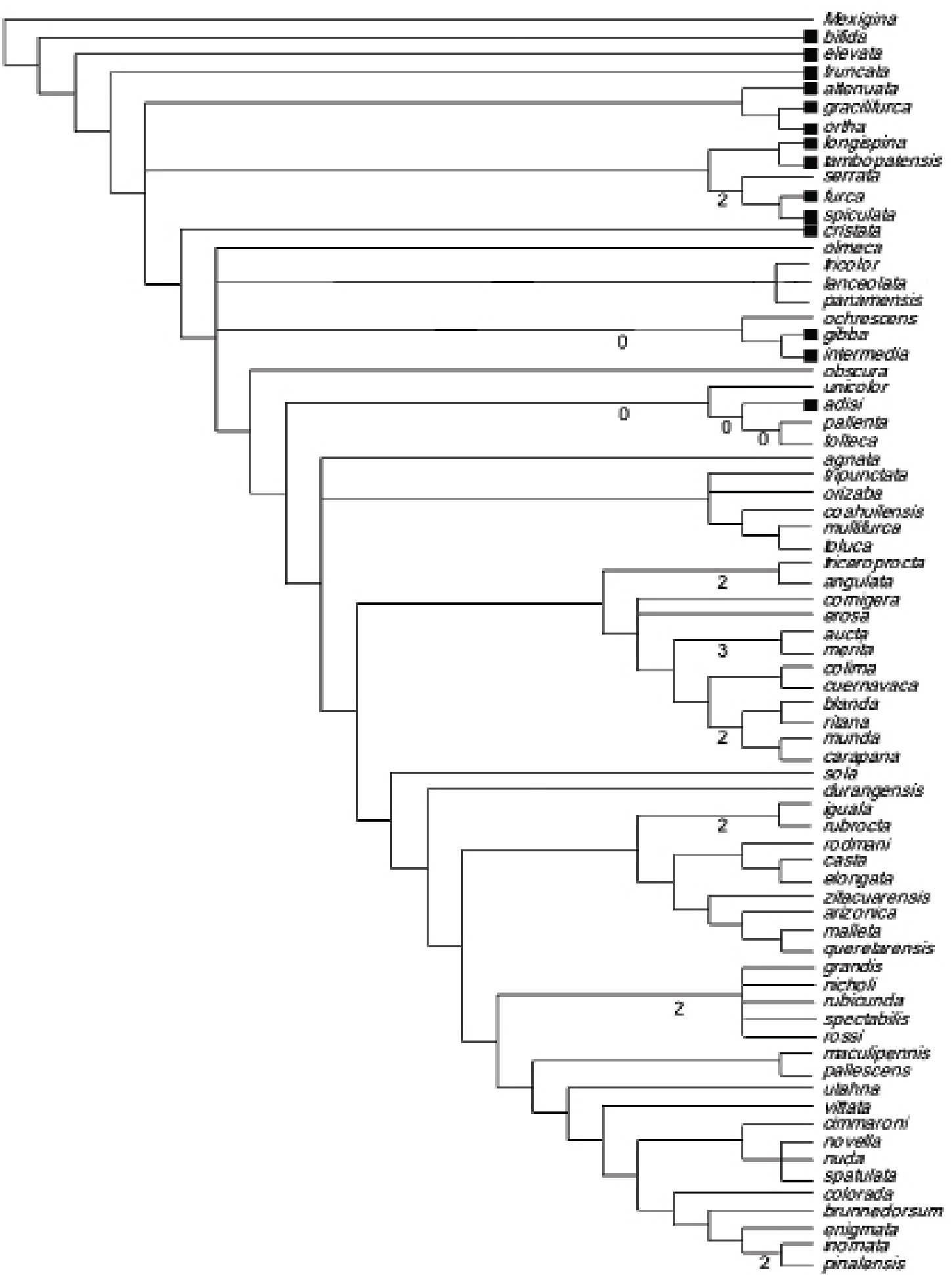

Figure 1. Adams consensus of 1,270 equally parsimonious trees from analysis of data matrix in Appendix B. All consistently resolved nodes had decay index $=1$ except as indicated. Nodes with decay index $=0$ collapsed in the strict consensus. Black squares indicate endemic South American species. 


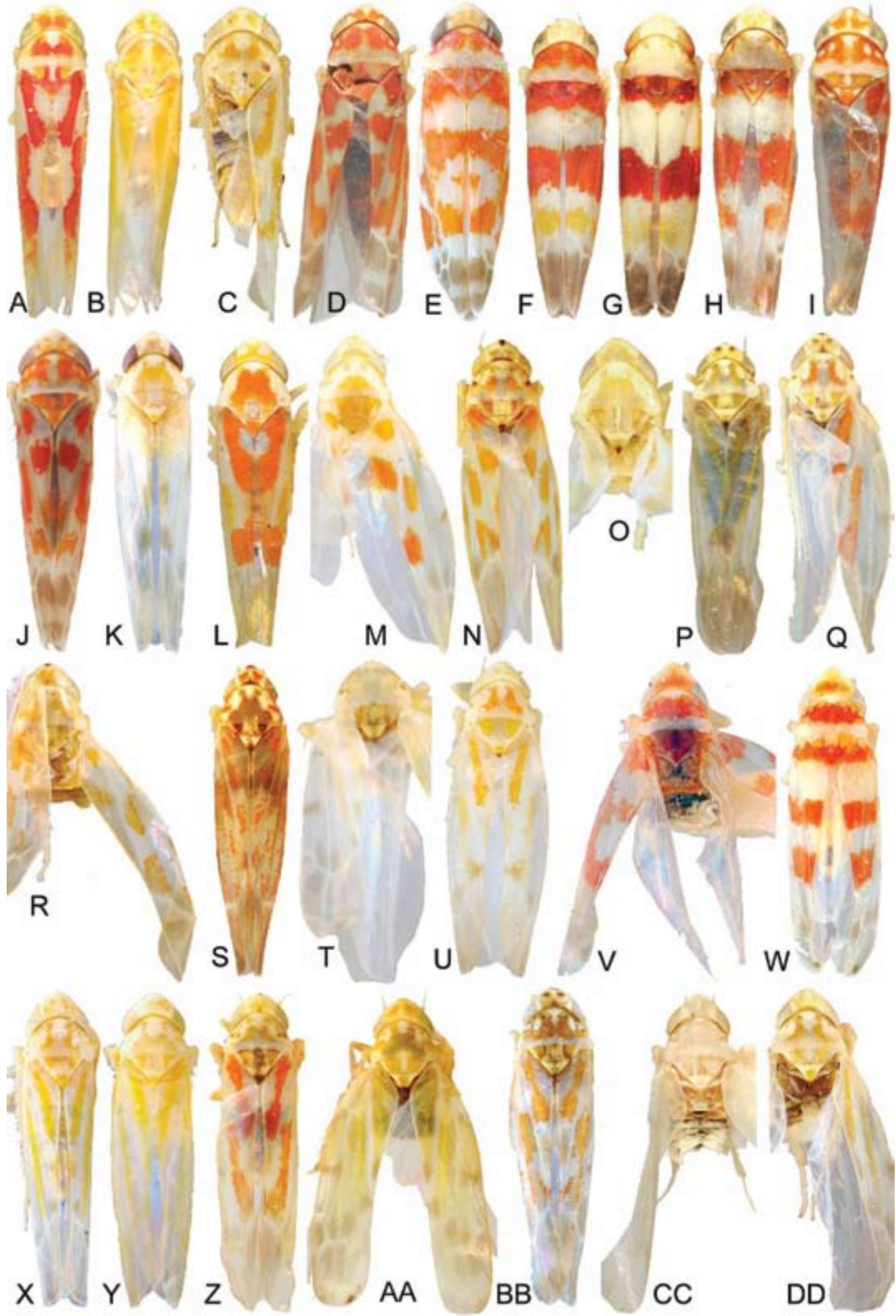

Figure 2. Zyginama spp., dorsal habitus of North American species (not to scale). A, Z. aucta; B, Z. merita; C, Z. dentata (lectotype female); D, Z. grandis; E, Z. spectabilis; F, Z. nicholi (holotype); G, Z. nicholi (female paratype of Z. ales); H, Z. nicholi (male paratype of Z. canyonensis); I, Z. rubicunda (holoype female); J, Z. rossi; K, Z. munda; L, Z. ritana; M, Z. maculipennis; N, Z. cuernavaca; O, Z. carapana; P, Z. tripunctata; Q, Z. coahuilensis; R, Z. orizaba; S, Z. rodmani; T, Z. malleta; U, Z. zitacuarensis V, Z. rubrocta; W, Z. iguala; X, Z. novella; Y, Z. arizonica; Z, Z. elongata; AA, Z. enigmata; BB, Z. queretarensis; CC, Z. obscura (holotype male); DD, Z. angulata. 


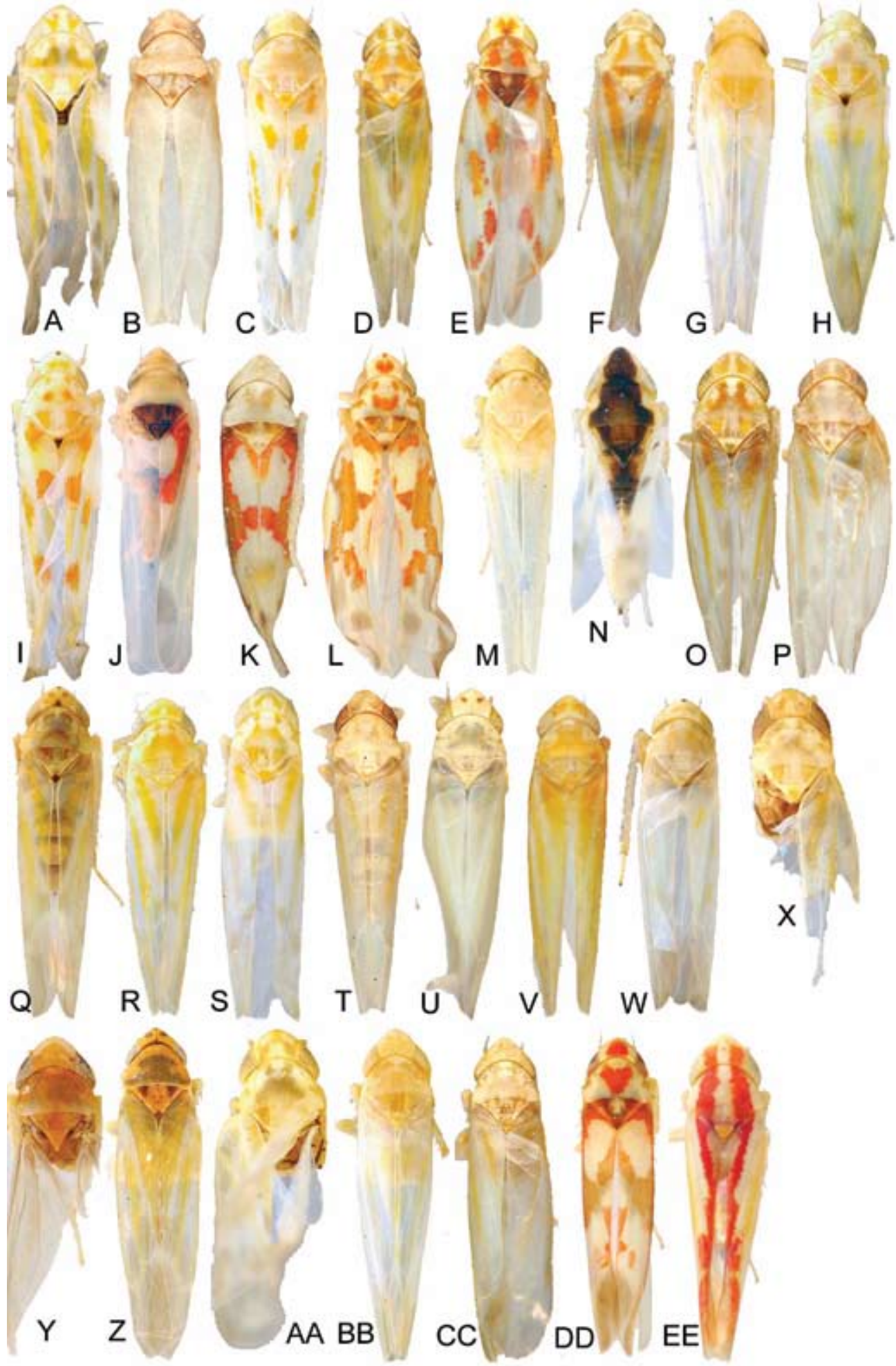

Figure 3. Zyginama spp., dorsal habitus of new North American species (not to scale). A, Z. durangensis; B, Z. unicolor (holotype male); C, Z. sola; D, Z. cornigera; E, Z. erosa; F, Z. casta; G, Z. agnata; H, Z. panamensis; I, Z. colima; J, Z. lanceolata; K, Z. tricolor; L, Z. tolteca; M, Z. nuda; N, Z. brunnedorsum; O, Z. pinalensis (holotype male); P, Z. triceroprocta (holotype); Q, Z. multifurca; R, Z. colorada; S, Z. vittata; T, Z cimmaroni; U, Z. inornata; V, Z. utahna (holotype male); W, Z. serrata; X, Z. spatulata; Y, Z. ochrescens; Z, Z. toluca; AA, Z. pallescens; BB, Z. blanda; CC, Z. pallenta (holotype male); DD, Z. olmeca; EE, Z. ternaria (holotype female). 

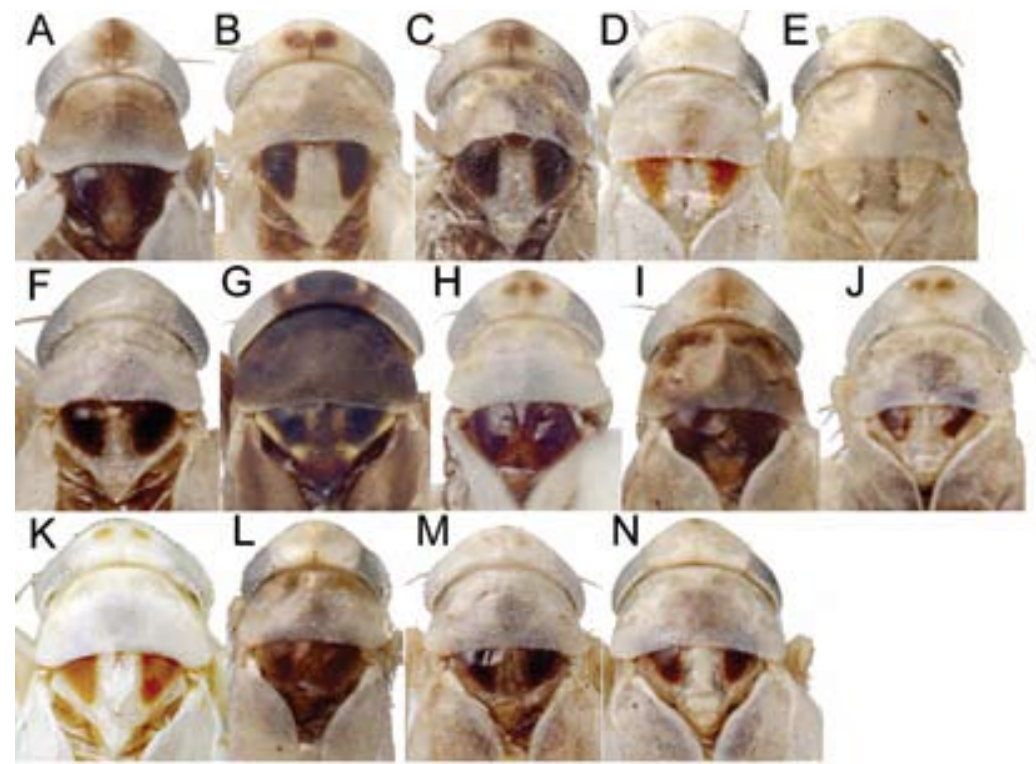

Figure 4. South American species provisionally placed in Zyginama, dorsum of head and thorax (not to scale). A, Z. gibba; B, Z. longispina; C, Z. tambopatensis; D, Z. furca; E, Z. spiculata; F, Z. cristata; G, Z. elevata; H, Z. gracilifurca; I, Z. intermedia; J, Z. adisi; K, Z. bifida; L, Z. truncata; M, Z. ortha; N, Z. attenuata. 

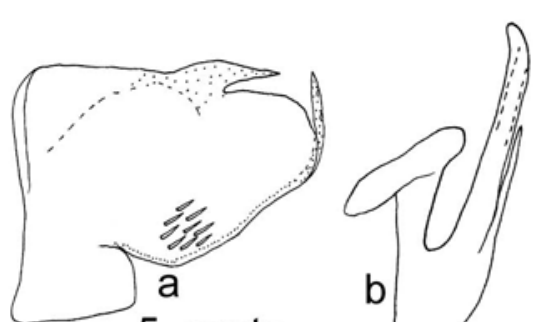

5. aucta

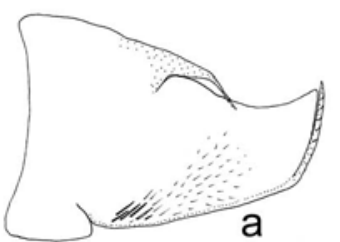

7. grandis
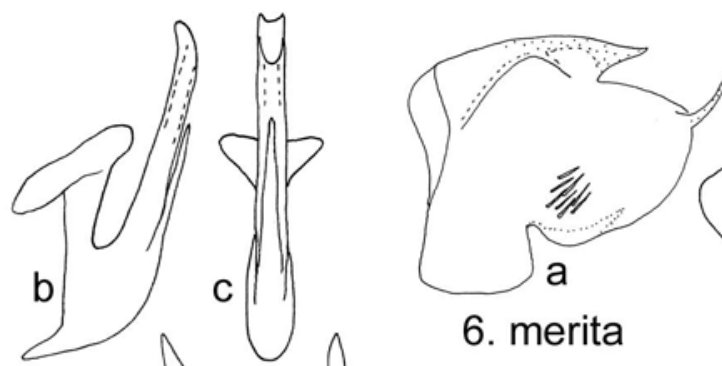

6. merita
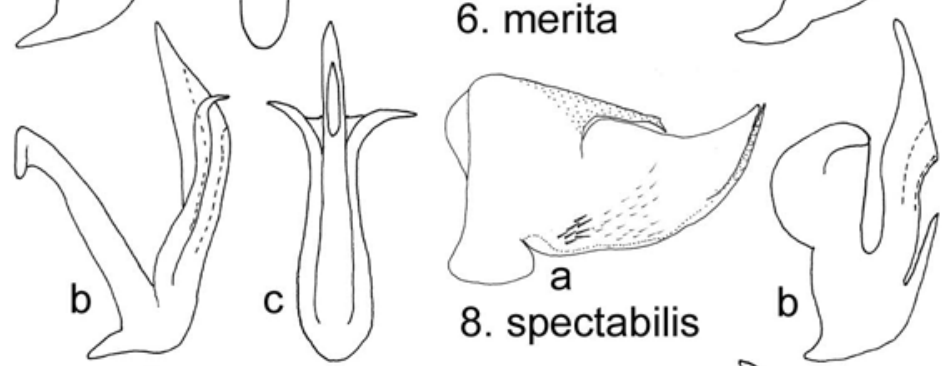

C
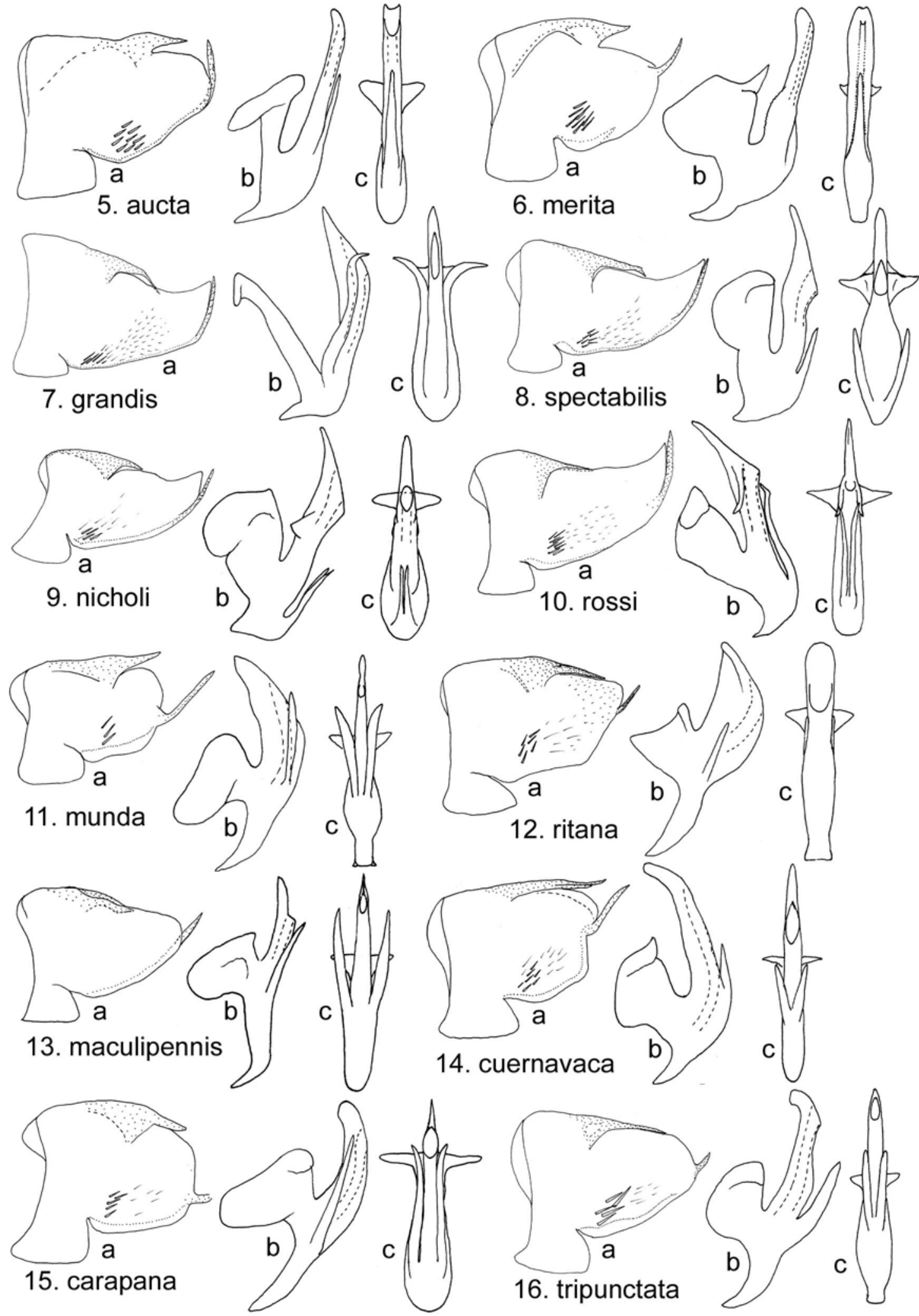

Figures 5-16. Zyginama spp., male genitalia: a, pygofer, lateral view; b, aedeagus, lateral view; c, aedeagus, posterior or posteroventral view. 

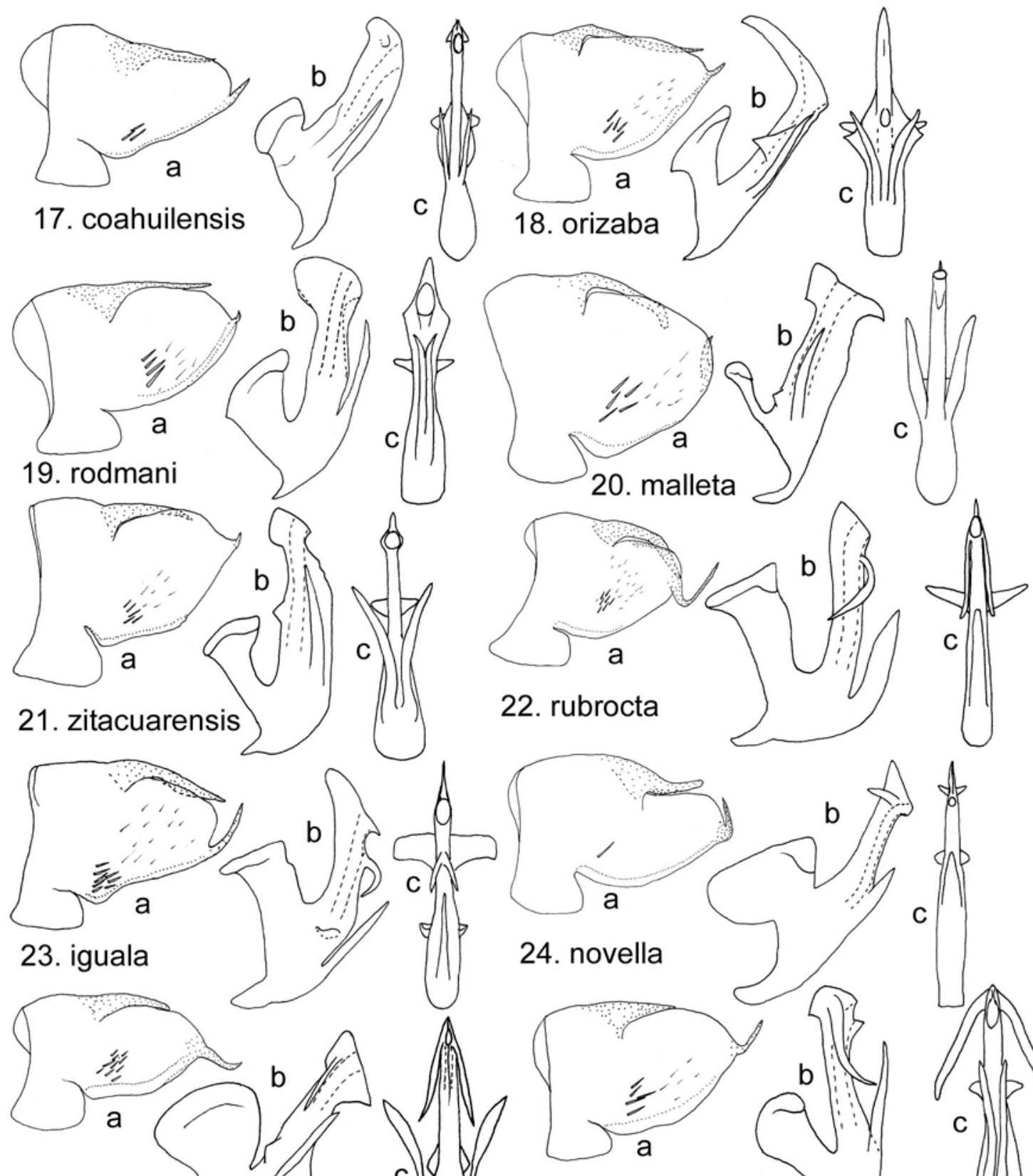

25. arizonica
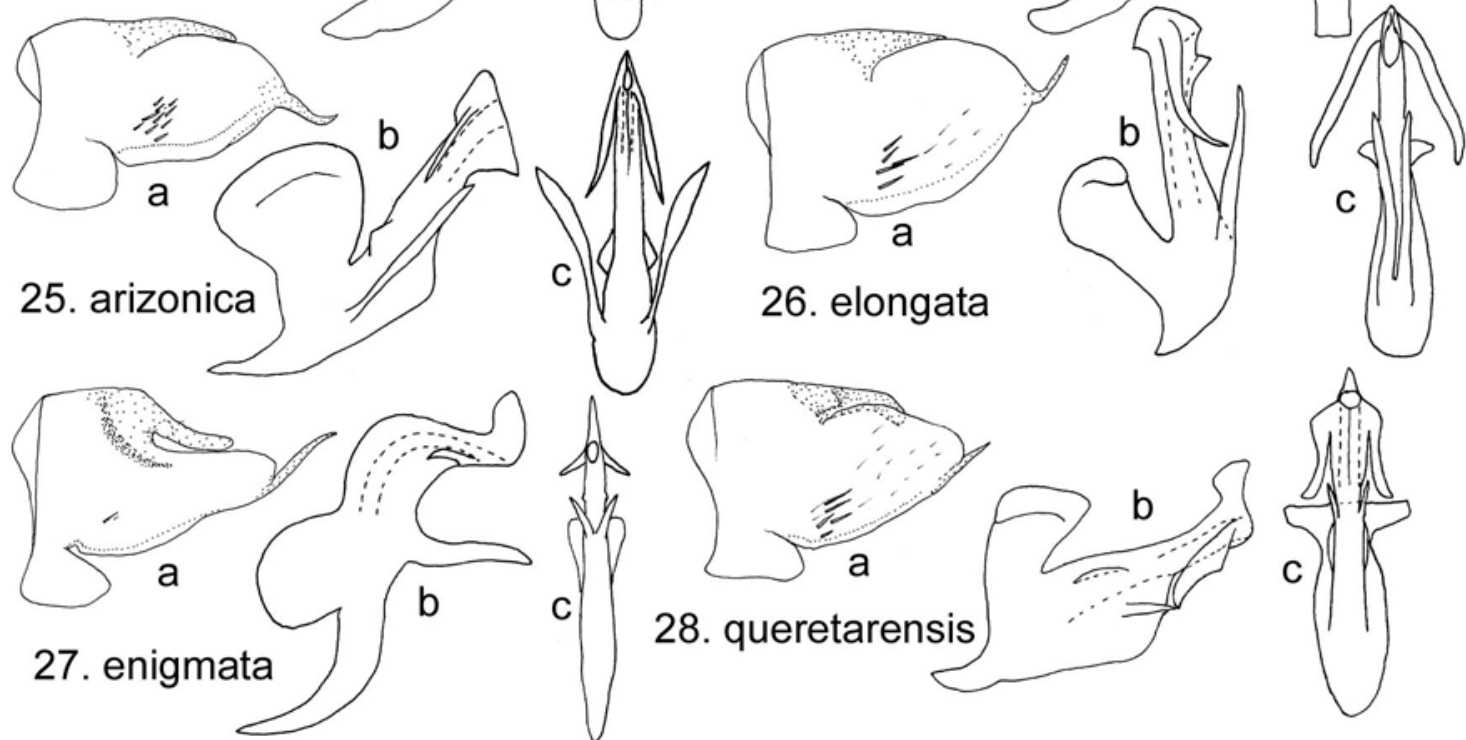

Figures 17-28. Zyginama spp., male genitalia: a, pygofer, lateral view; b, aedeagus, lateral view; c, aedeagus, posterior or posteroventral view. 

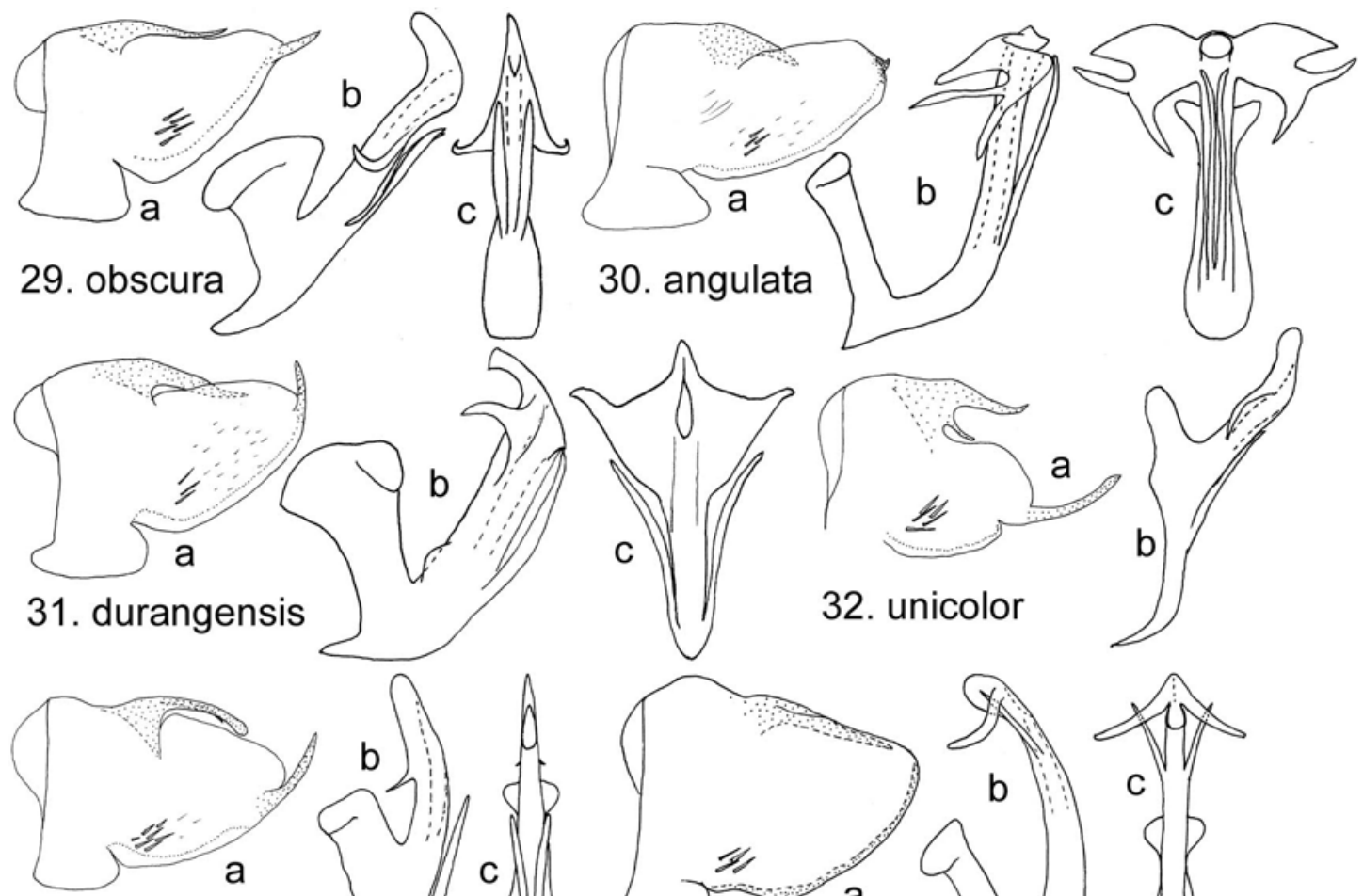

33. sola

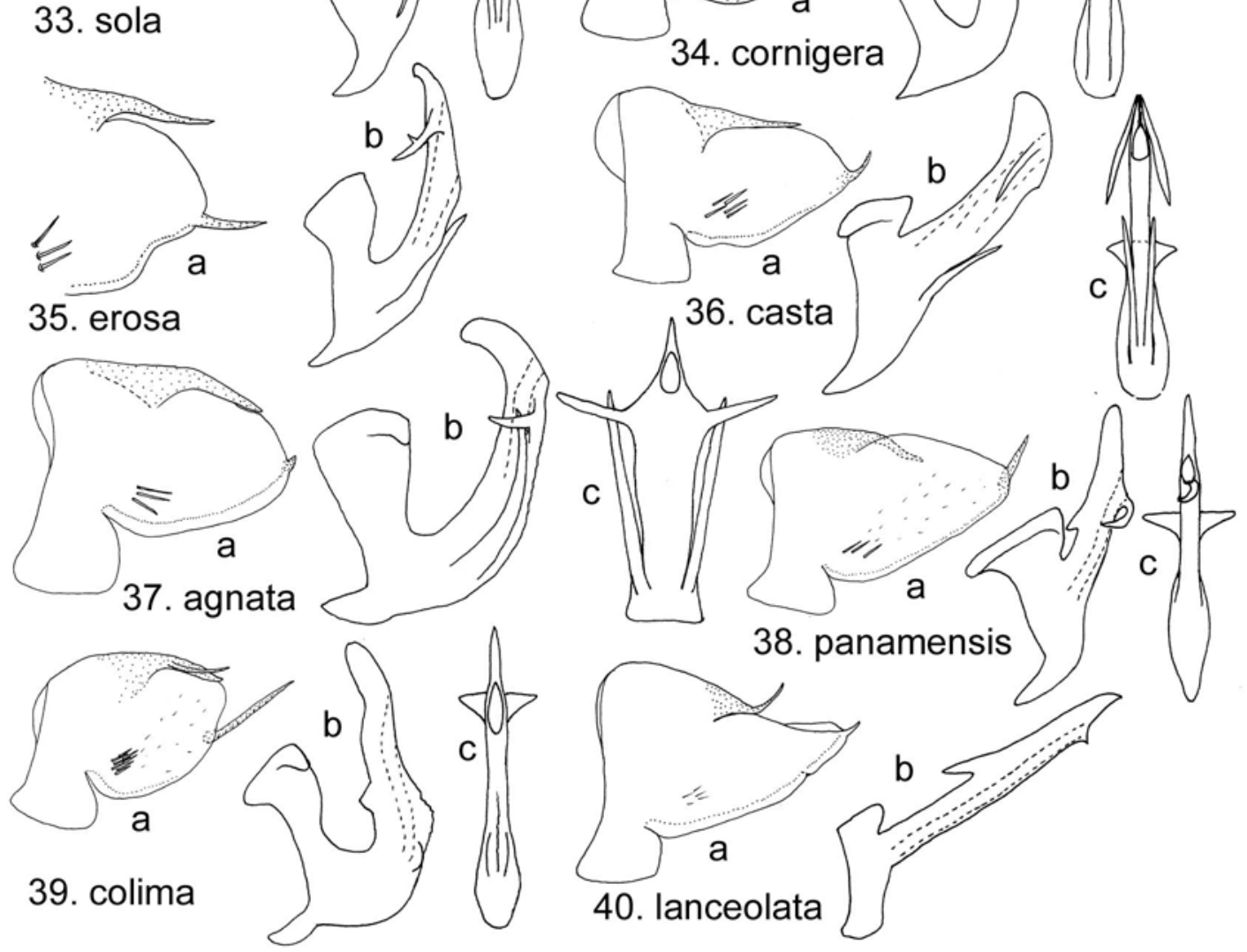

35. erosa
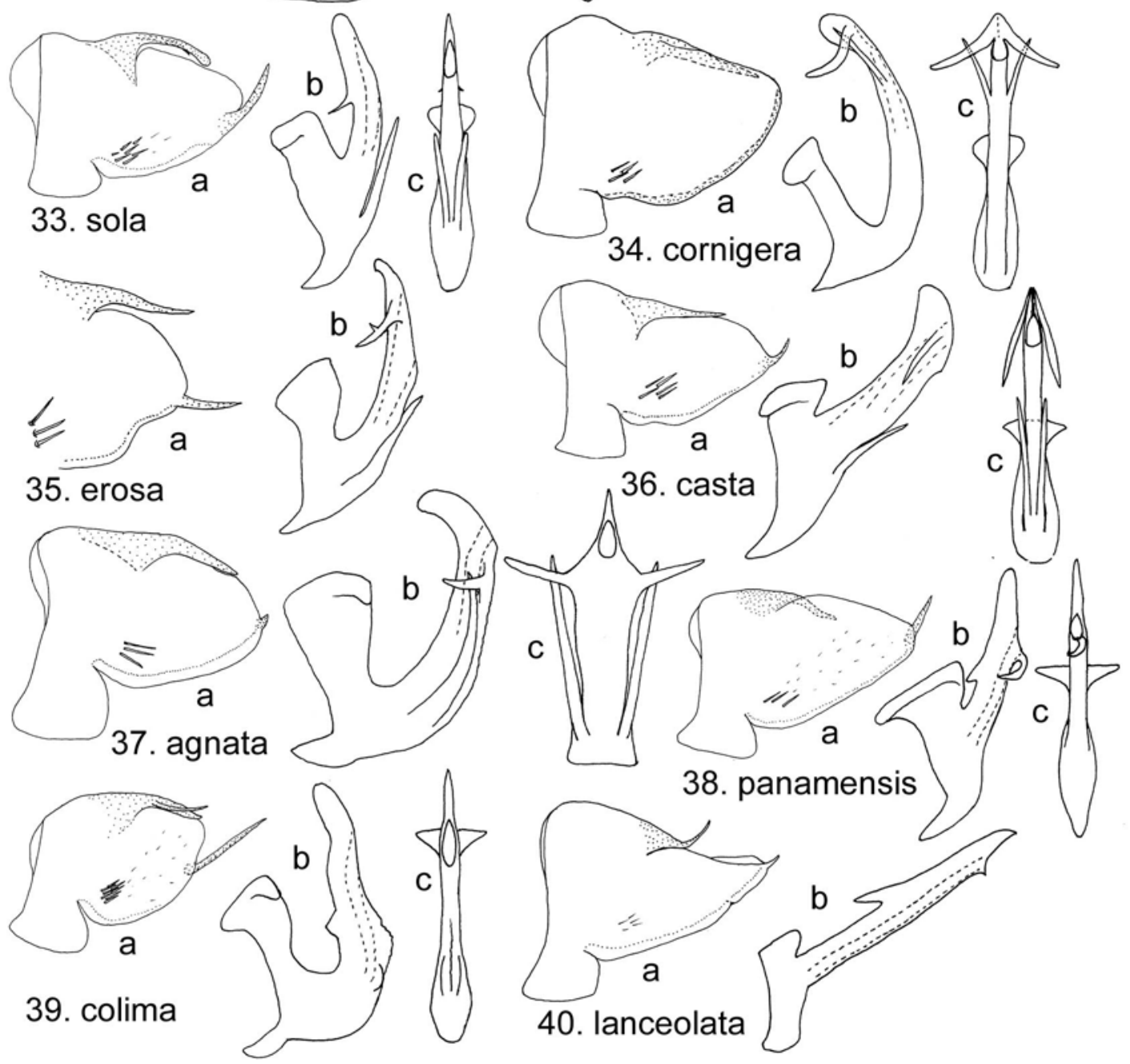

32. unicolor

Figures 29-40. Zyginama spp., male genitalia: a, pygofer, lateral view; b, aedeagus, lateral view; c, aedeagus, posterior or posteroventral view. 

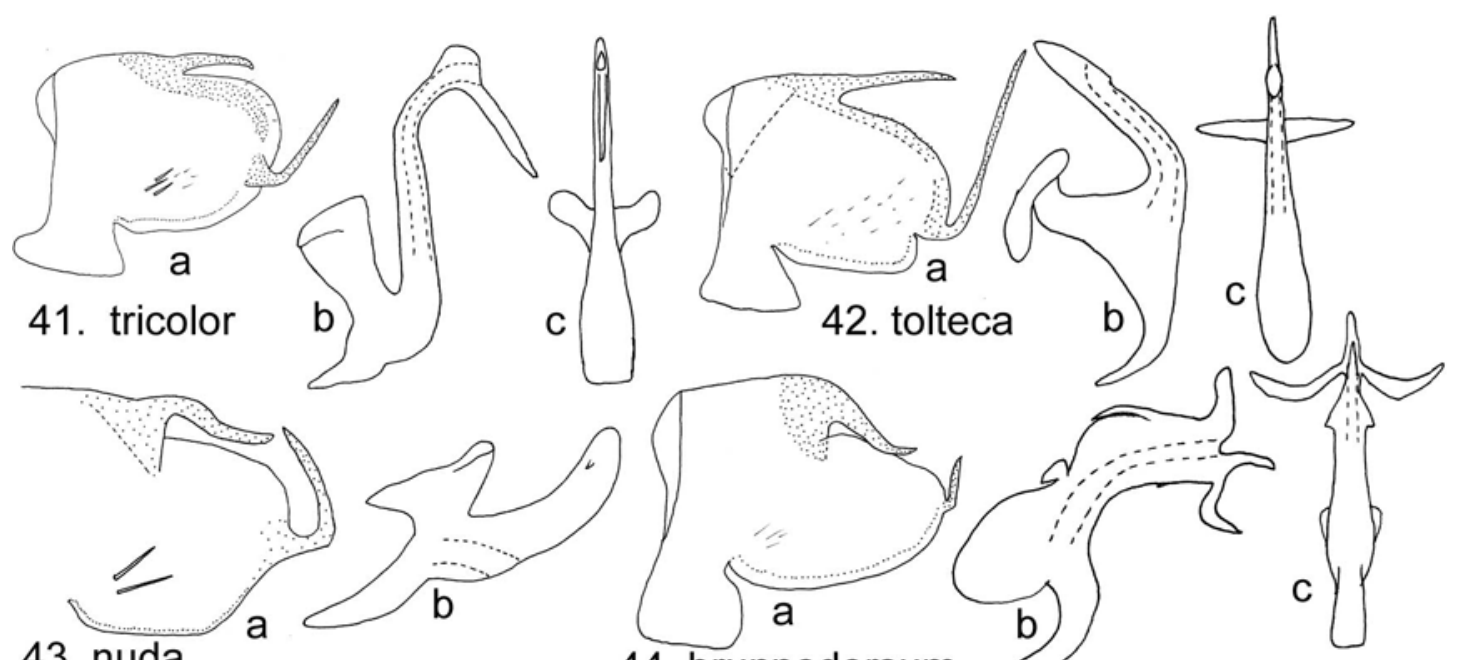

43. nuda
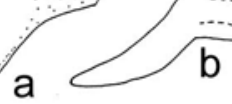

b

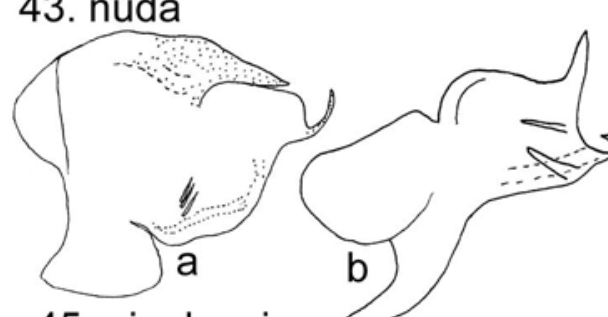

45. pinalensis

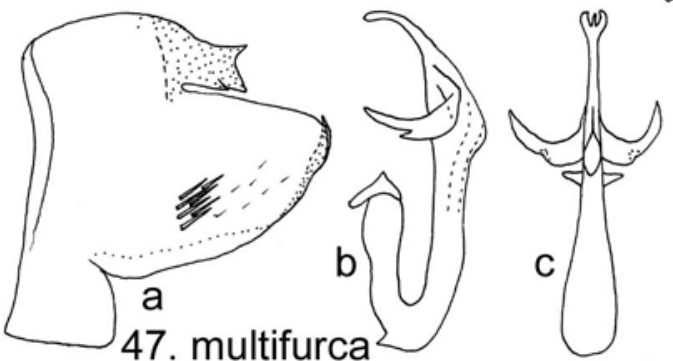

44. brunnedorsum
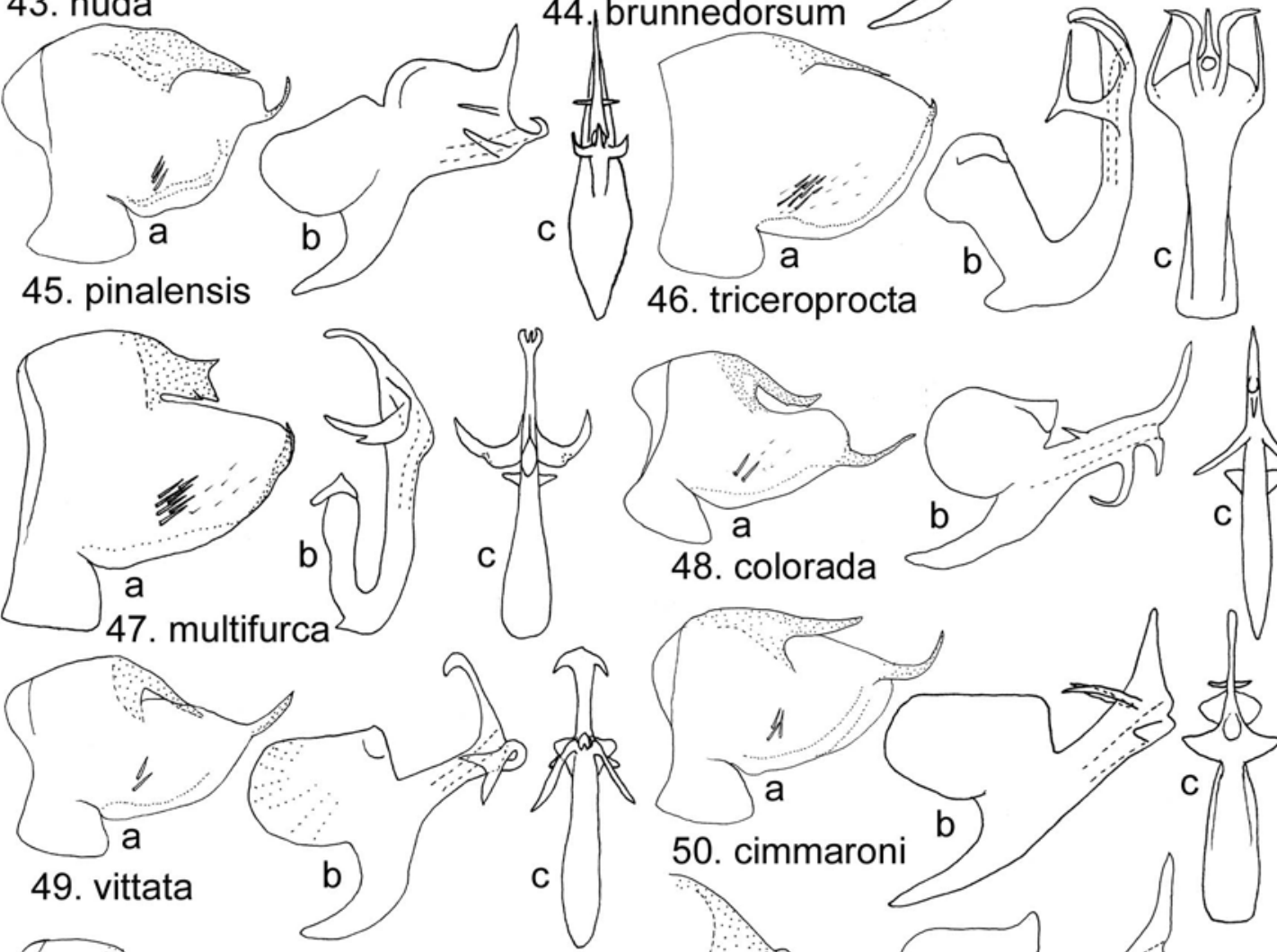

46. triceroprocta
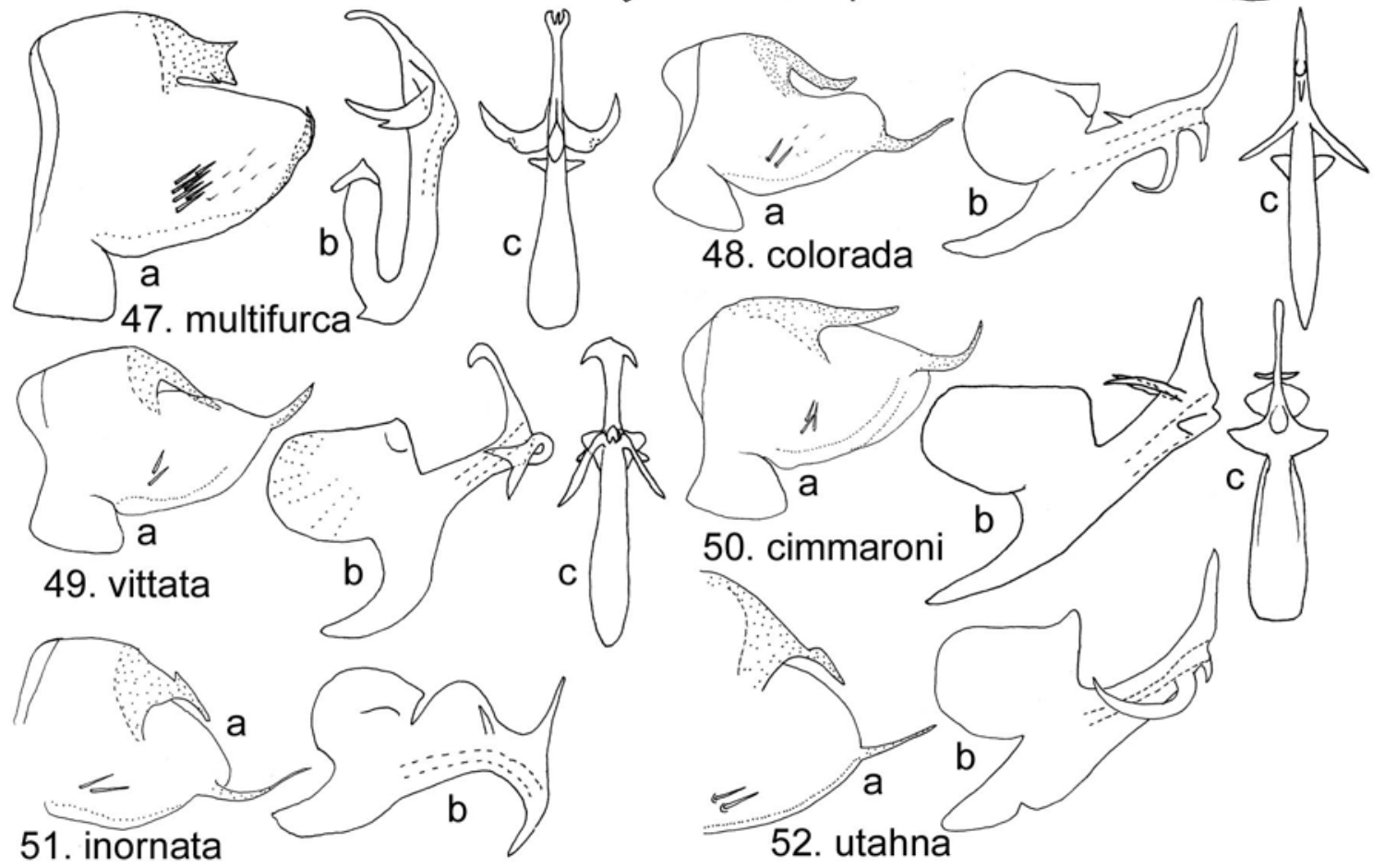

Figure 41-52. Zyginama spp., male genitalia: a, pygofer, lateral view; b, aedeagus, lateral view; c, aedeagus, posterior or posteroventral view. 


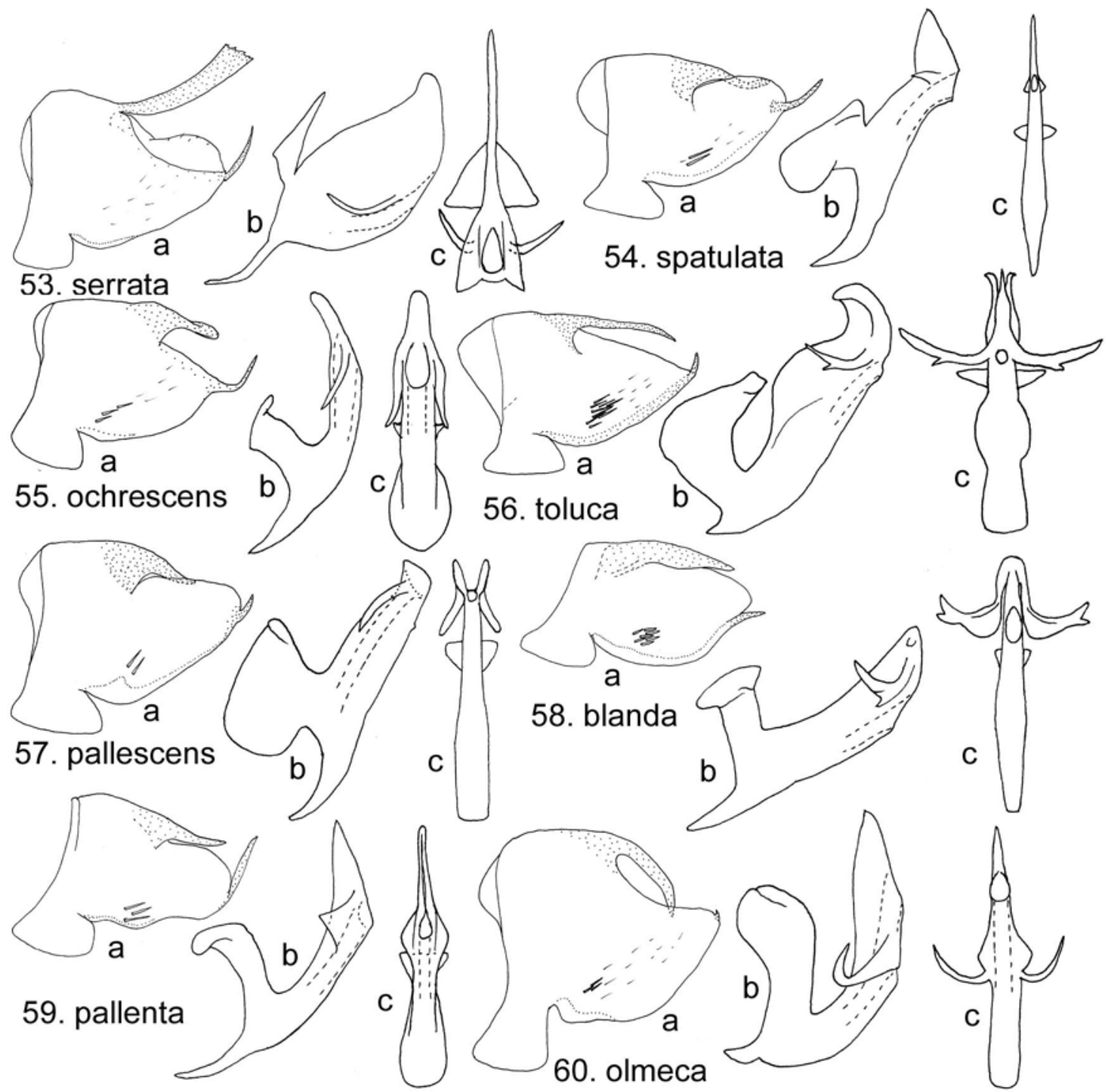

Figure 53-60. Zyginama spp., male genitalia: a, pygofer, lateral view; b, aedeagus, lateral view; c, aedeagus, posterior or posteroventral view. 


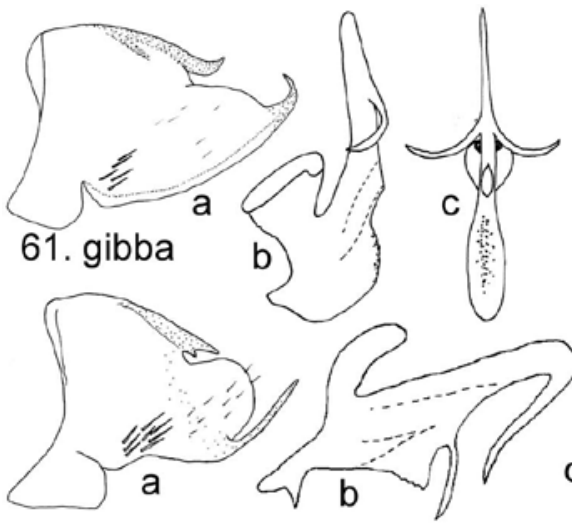

63. tambopatensis

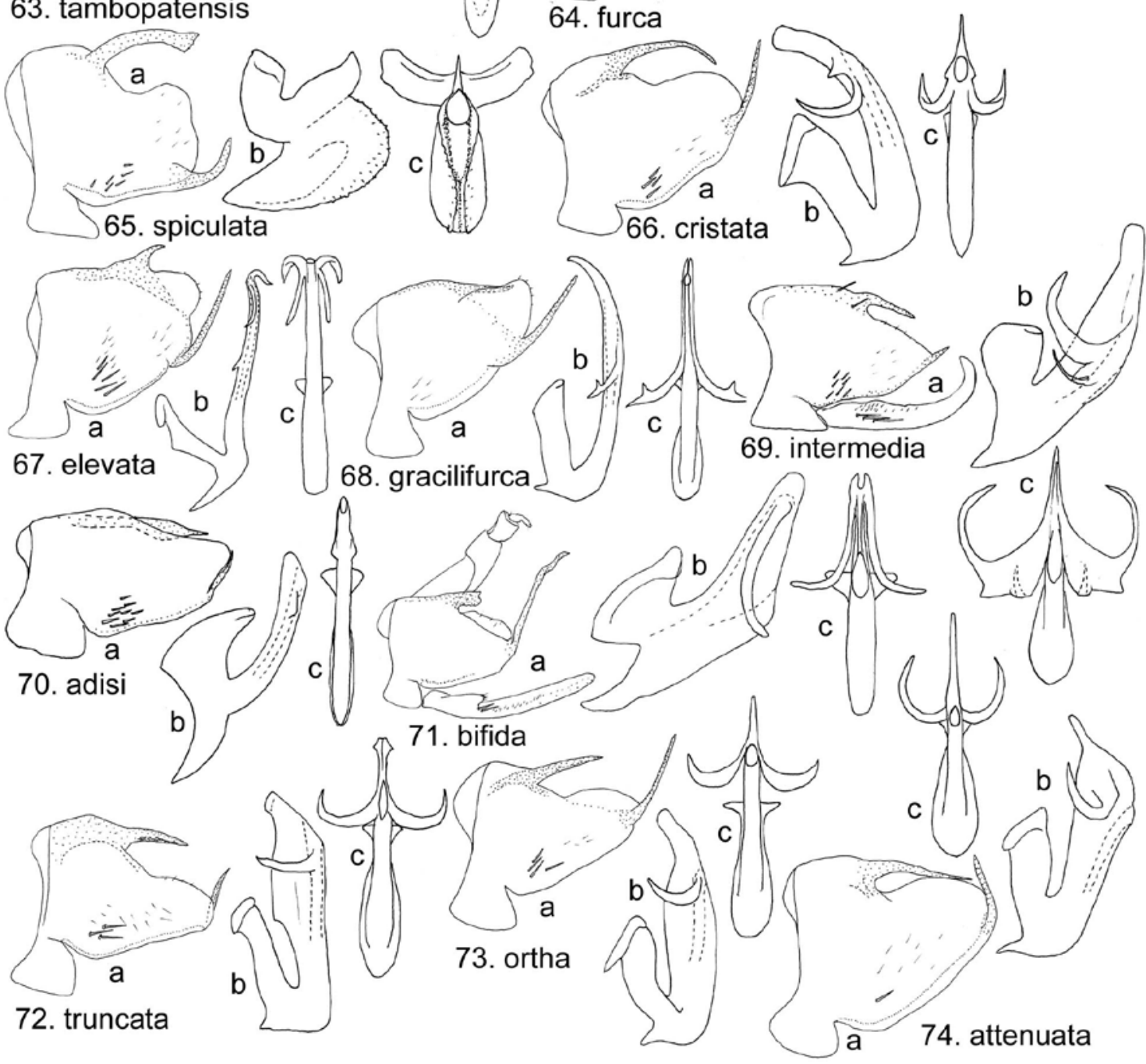

Figures 61-74. South American species provisionally placed in Zyginama, male genitalia: a, pygofer, lateral view (except 69a, pygofer and subgenital plate; 71a, entire genital capsule); b, aedeagus, lateral view; c, aedeagus, posterior or posteroventral view. 
Notes 

Illinois Natural History Survey

I-Building

1816 South Oak Street

Champaign, Illinois 61820

217-333-6880

A Division of the Illinois Department of Natural Resources

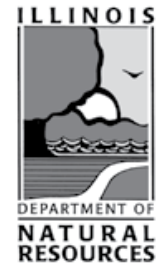

ISBN 978-1-882932-16-0 